Florida International University FIU Digital Commons

FIU Electronic Theses and Dissertations

University Graduate School

$11-12-1998$

\title{
The social development strategy of the shiites in Lebanon
}

Serge R. Akl

Florida International University

DOI: $10.25148 /$ etd.FI13101556

Follow this and additional works at: https://digitalcommons.fiu.edu/etd

Part of the International and Area Studies Commons

\section{Recommended Citation}

Akl, Serge R., "The social development strategy of the shiites in Lebanon" (1998). FIU Electronic Theses and Dissertations. 1222. https://digitalcommons.fiu.edu/etd/1222

This work is brought to you for free and open access by the University Graduate School at FIU Digital Commons. It has been accepted for inclusion in FIU Electronic Theses and Dissertations by an authorized administrator of FIU Digital Commons. For more information, please contact dcc@fiu.edu. 
Florida International University

Miami, Florida

THE SOCIAL DEVELOPMENT STRATEGY OF THE SHIITES IN LEBANON

A thesis submitted in partial satisfaction of the

requirements for the degree of

MASTER OF ARTS

IN

INTERNATIONAL STUDIES

by

Serge R. Akl 
To: Arthur W. Herriott

College of Arts and Sciences

This Thesis, written by Serge Roger Akl, and entitled The Social Development Strategy of the Shiites in Lebanon, having been approved in respect to style and intellectual content, is referred to you for judgement.

We have read this thesis and recommend that it be approved.

Dr. Nicholas Onuf

Dr. Mohiaddin Mesbahi, Major Professor

Date of Defense: November 12, 1998

This Thesis of Serge Roger Akl is approved.

Dr. Charles MacDonald

Dean Árthur W. Herriott

College of Arts and Sciences

Dean Richard L. Campbell

Division of Graduate Studies

Florida International University, 1998 
(C) Copyright 1998 by Serge R. Akl

All rights reserved 
To the memory of Eli Akl,

and to my friend Alexi, who fell too young,

victim of Lebanon's senseless war. 


\section{ACKNOWLEDGEMENTS}

I am indebted to many people for the completion of this thesis, and in the following lines I will attempt to express my appreciation to those who have contributed to my personal and educational success.

First, there would be no Serge Akl if it were not for the love and dedication of my wonderful family; I would therefore like to thank my mother for the unyielding love she incessantly gives a son who has not always deserved it; and to my father for his love, and for his attention and support to my academic career. Without their ever present commitment and struggle for the betterment of my life, I would be nothing.

I especially would like to thank my professors; Dr. Onuf, Dr. Mesbahi, and Dr. MacDonald for their support and guidance, and for showing me that any undertaking is attainable given the right amount of effort. To my friend Majid, I must attribute the memory of long hours of productive discussion on the topics of Christianity and Islam. We have found that dialogue can be the source of real understanding and a vehicle for compromise and peace.

Finally, I must mention all those who have helped me in Lebanon: Amal, and Hizb Allah leaders; the Maronite Church, Karim Pakradouni, and many others who generously helped in my fact finding trip to my native country. Last but not least, my special thanks go to my wonderful friends who made it their responsibility to show me a good time during my stay in Beirut, especially Emile, Ralph, and Carine. 


\section{ABSTRACT OF THE THESIS}

THE SOCIAL DEVELOPMENT STRATEGY OF THE SHIITES IN LEBANON

by

Serge R. Akl

Florida International University, 1998

Miami, Florida

Professor Mohiaddin Mesbahi, Major Professor

This study examines what many scholars have neglected to investigate when addressing post Civil War issues in Lebanon. Most studies have addressed political issues surrounding activities of Shiite movements, such as Harakat Amal or Hizb Allah, while socioeconomic issues have been neglected.

Imam Musa Sadr challenged the power of traditional Shiite leaders by creating official Shiites institutions and movements like Amal. The Iranian Revolution and the Israeli invasion of Lebanon in 1982 sparked the creation of Hizb Allah which, not only struggled against its foes, but also provided social services to the Shiites. This development program has been central in creating political legitimacy for Hizb Allah, regardless of its military situation, which suggests that socioeconomic development can transform a militia into a legitimate actor on the Lebanese political scene. The survivability of Shiite parties is therefore tantamount to not only their military might, but also to their social involvement. 
Chapter

Page

Introduction 1

Chapter I: History of the Shiites in Lebanon 10

Imam Musa Sadr and the Transformation of Shiite Political Thought. 18

The Palestinian Equation 26

Amal and its Role. 31

Hizb Allah, or the Fundamentalist re-Awakening 37

Chapter II: Harakat Amal, Hizb Allah and the Provision of Social Services

Harakat Amal. The Office of Health and Social Services........................ 51

Hizb Allah's Social Services................................................................ 56

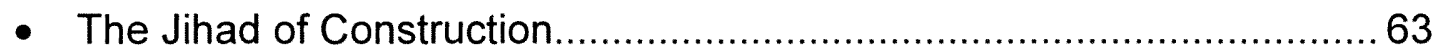

- The Islamic Institute for Education and Instruction ............................... 80

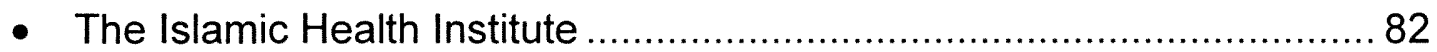

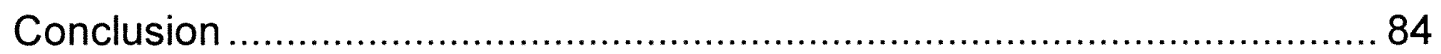

Chapter III: The Maronite Dimension ................................................... 88

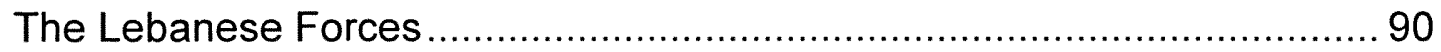

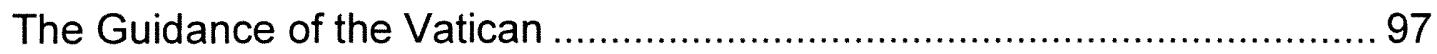

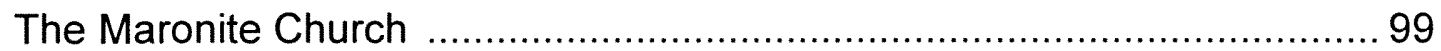

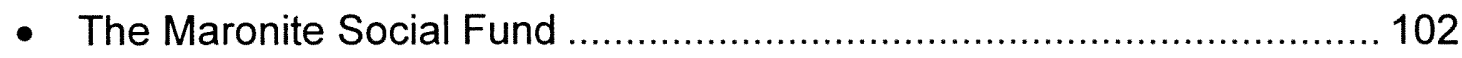

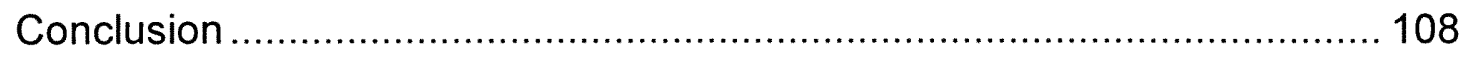

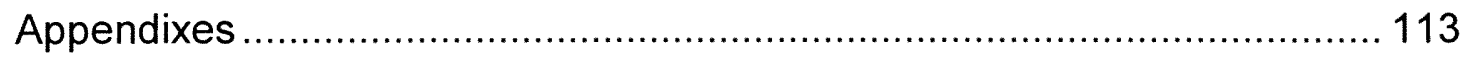


Afwaj al Muqawama al Lubnaniya (AMAL): Battallions of the Lebanese Resistance

Al Hai'a al Islamiya al Sahiyya: the Islamic Health Institute Al Hai'a al Islamiya lil Tarbia: the Islamic Education Institute Al Kuwat al Lubnaniya: the Lebanese Forces

Al Sunduq al ljtimaai al Marouni: the Maronite Social Fund

Allah: God Haraka: movement

Harakat al Mahrumin: the Movement of the Deprived Harakat Amal: Amal Movement

Hizb Allah: the Party of God

Hizb: political party

Imam: spiritual leader

Jihad al Bina': Jihad of Construction

Jihad: Holy struggle

Jihaz Bachari: Human work group

Madhab: religious rite

Zaim: traditional leader or patron

Zuama: plural of Zaim 
I was born in Lebanon in 1972 and I grew up there until the age of eleven. I have very little or no memory of my native country before the civil war started in 1975 , and I left it by sea in 1983 after the Israeli invasion and the formation of the multi-national peace keeping force. As I continued my education, I always had a great interest in the politics and history of the land of my ancestors, and that played an important role, along with my life in Europe and the United States, in my decision to acquire and pursue an education in International Relations and global politics.

To an outsider, Lebanon is seldom an easy country to understand with its eighteen different confessions and its democratic, yet weak institutions.

Surprisingly, to an insider it is even more of a problem to understand and explain the dynamics of Lebanon's politics because of the emotional baggage and personal experience each individual carries everyday of his life. Generally speaking, as a Catholic Maronite, I undoubtedly will have a different outlook on Lebanon's history and future compared to a Druze, or a Sunni, or a Shi'a compatriot. This is one of the reasons why I have chosen to investigate social issues in Lebanon in contrast to political ones. Of course, these two criteria are interrelated, but concentrating on the social side of Lebanon's situation is more interesting to me than relating the pulling and hauling, the politicking and under the table agreements of Lebanon's historically corrupt political elite. Moreover, the vast majority of the literature in the United States concentrates on the political or security aspect of the Lebanese state with little or no attention paid to the present social situation of the people.

In addition, studying the social aspect of the two largest religious communities in Lebanon --the Shiites and the Maronites-- can give a better 
picture of the situation of the country and its people. In doing so, one needs to understand that the Lebanese government has historically been a weak institution with little interest in making the lives of its citizens more comfortable. Consequently, what is interesting to investigate is the response of each religious community to a perceived situation of abandonment by the state. Indeed, one can uncover community organizations for each religious group which are directly created from within these groups in order to primarily cater to the basic needs of the targeted population. For example, the Maronite Church will primarily have programs to help the Maronite community just as predominantly Shiite parties like Amal or Hizb Allah will work for the betterment of the Shiite population. This does not mean that these programs are only meant to aid solely one religious group, as many programs from different organizations have a national impact. However, in a political system based on confessional criteria, the most admirable national and universal programs have an almost natural tendency to revert to a more precise target group embodied by the religious affiliation of the people. That is why this study approaches social organization through religion, especially in the absence of any truly national program from the state.

The Shiite community of Lebanon is the main target of this study, but I will investigate the social infrastructure of the Maronite community as well, with the hope of bringing a wider picture to the study of social issues in Lebanon. The evolution of the Shiite and Maronite communities has followed different paths because of their different past and because of the different goals of their political and religious leaders. Accordingly, my approach and analysis of each religious community will follow different criteria which will be discussed at length in each part.

The Shiites and the Maronites, however, have lived together in Lebanon for centuries and have found ways to cooperate, to compromise and, above all, 
to engage in an ongoing dialogue; a dialogue between people of different backgrounds, religions, and ideologies. These differences translate into different political inclinations and alignments both nationally and internationally. This phenomena is what is usually investigated in literature concerning Lebanon; what is surprisingly neglected in the study of this confessional state is the social organization and mobilization of each community. Indeed, the different religious groups, guardians of their own particularistic ideologies, will have different community identities and thus different types of social organization. In turn, these different social approaches might affect the politics of each community. This is why community socioeconomic development is interesting to study as it can truly play a role in the politics of the small pluralistic state.

The second half of this century has witnessed great activity in Shiite political and social mobilization. In fact, my particular interest in the Shiites of Lebanon stems from their being the most dynamic actor in Lebanon today. The fuel of this change has been the will of Shiite leaders to improve the socioeconomic condition of their community. The sense of deprivation and oppression is at the heart of Shiite politics, but is seldom examined in detail by contemporary literature. Movements like Amal and Hizb Allah are actors at the national level and do play a political and military role in Lebanon; they forge alliances in Lebanon and enjoy foreign support -tactical or financial- from Syria or Iran. However, these Shiite parties are competing for the support of the Shiite population. The life of an individual in Lebanon starts with his family, his village and his religious community before any identification with the state. That is one of the reasons why Amal and Hizb Allah attempt to command political legitimacy by offering a wide array of social programs. In the case of Hizb Allah, for example, certain social programs are part of the resistence effort against the state of Israel in the South (the rebuilding of damaged homes). Furthermore, in 
the advent of peace between Lebanon and Israel, Hizb Allah will be disarmed and would have to abandon its military resistance; the raison d'etre of the Shiite movement will have to become domestically oriented and focused around political and social programs. It is therefore safe to assume that the political survivability of Hizb Allah and of other parties and movements will heavily depend upon the application of a well organized development strategy. This, in turn, could have wider ramifications for the future nature of the Lebanese state. Consequently, concentrating slolely on political and security matters concerning the Shiite community in Lebanon cannot adequately serve the full understanding of that community by scholars. Moreover, as socioeconomic development is a relatively new occurrence for the Shiite community, most of the available literature on Lebanon could not serve my interest in this research.

Kamal Salibi's Modern History of Lebanon examines sectarian politics in Lebanon from the Shehab Emirate to the first steps of independent Lebanon. It is an interesting account of the ways different religious sects interacted under different regimes of foreign rulers and how sectarianism prevailed after independence; but there is no focus on social politics. Similarily, Salibi's widely read Crossroads to Civil War mainly examines the political causes of the conflagration of the Lebanese Civil War in the mid seventies. Michael Hudson's Precarious Republic examines modernization in Lebanon in the late 1960's. It is obviously not recent enough to relate the Shiite social mobilization since the seventies, and examines state sponsored modernization not community development. Perhaps due to the end of the Civil War, more recent books on Lebanon almost always concentrate on relating political, military, and strategic issues. For example, Robert Fisk's Pity the Nation: The Abduction of Lebanon, examines the Lebanese conflict by concentrating on the Israeli invasion, the role of the PLO in Lebanon, and the taking of hostages. Charles Winslow's Lebanon: 
War and Politics in a Fragmented Society, is an interesting account of Lebanese political and historical life that spans from ancient to present times. Social politics and community organization, however, are not examined. William Harris' Faces of Lebanon: Sects, Wars, and Global Extensions discusses the multicommunal nature of Lebanese society in a refreshingly lucid and clear expose. His interest lies in the diversity of Lebanese society and in the dynamic relations between the different religious communities. However, Harris approaches the matter by presenting a chronological historical account of Lebanese politics from independence to today; his interest in the different communities is of a political and geopolitical nature and does not intend to explain the intricacies of social identities and their effect on the socioeconomic changes of community life and organization.

The literature available on the Shiites of Lebanon, in particular, is also limited. Most are scholarly studies made for the nonspecialist reader and relate mostly the historical and political aspect of Shiism in the Middle East and in Lebanon. Magnus Ranstorp's Hizb' Allah in Lebanon: The Politics of the Western Hostage Crisis examines political and geopolitical influences on Hizb Allah and focuses on hostage taking, but does not investigate the social condition of the Shiites or the social programs offered by Hizb Allah.

The books that I find most important in the study of the Shiites in Lebanon are Fouad Ajami's work on Imam Musa al Sadr, The Vanished Imam, and Richard Norton's Amal and the Shiia. Ajami shows the great and pivotal impact Imam Musa al Sadr had on the organization of Shiia politics in Lebanon, and his work is cited by most authors who study the Shiites of Lebanon. Indeed, if the role that al Sadr played in the evolution of Shiia politics from a clientelistic system to a system of vast social movements, a revolution in Lebanese politics, is not understood, then the Shiites can not be understood. Norton gives an in 
depth account of the inheritors of Musa al Sadr's legacy and Shiite politics until the mid eighties. Another more recent work on the Shiites of Lebanon is the book of Majed Halawi, A Lebanon Defied. The socioeconomic aspect of the Shiites' life is examined here and complements well the works of Ajami and Norton. General Hicham M. Jaber has been a career officer in the Lebanese Army and is the son-in-law of Sayyid Hussein El Husseini, the colleague and successor to Imam Musa Sadr at the head of the Amal movement. General Jaber has written a thesis and a dissertation at the Sorbonne University which have been very helpful to my work and research. His dissertation, Les Chiites $d u$ Jabal Amel (The Shiites of Jabal Amel), is an exhaustive work which examines the social, economic and political condition of the Shiites in Lebanon. Finally, Hala Jaber's Hizbollah: Born with a Vengeance attempts to offer a complete study of Hizb Allah and actually contains a chapter dealing specifically with the social work of the Shiite movement. Other studies on the subject are scarce. Many edited books have been published and can offer interesting information on the Shiites in general and on the Shiites of Lebanon, in particular. Cole and Keddie offer studies of the Shiite community throughout the Muslim world in Shiism and Social Protest. In John Esposito's edited work, The Iranian Revolution, an article by Richard Norton investigates the relationship between Iran and Lebanese Shiite political parties like Hizb Allah. What the literature lacks is focus on the social works of the Shiite political parties, the significance of this attention to the daily lives of the Shiite population, and its political ramifications. For this reason, I had to use personal interviews in Lebanon in order to get the information needed.

The process was not simple. Hizb Allah leaders, for example, are very suspicious of outsiders asking in depth questions about their organisation. They perceive the United States as being the unconditional ally of Israel, and, 
consequently, do not usually welcome American scholars, journalists, or students openly. References from highly placed officials in one of Lebanon's state institutions enabled me to visit an Amal official easily, but I was still required to build a trusting relationship with my counterparts in Hizb Allah. My main target was the social wing of the Amal movement and of Hizb Allah.

Being a Maronite made it easy for me to meet Christian officials and Maronite clergymen or monks. Overall, I was always received hospitably by all my hosts but with a certain degree of surprise at my academic focus on non security related topics, which again points to a major gap in the scholarship on Lebanon.

In the following pages, the first chapter will address the history of the Shiite community in Lebanon, and the transformation of its political consciousness and identity. From a quiescent and powerless community during the Arab and Ottoman Empires, the Shiites started to empower themselves through different means.

The creation of the state of Lebanon after World War I, under France's League of Nations Trusteeship, enabled the Shiite community's religious rite to be recognized as separate from the Sunni rite. This gave them official recognition from the state. However, the social and political situation of the Shiites was still ruled by a few land owning traditional families who organized the Shiite community along a patron-client relationship. It is with the advent of Imam Musa Sadr and the ensuing events of the Lebanese Civil War that the Shiite community was able to organize itself politically and socially along the party lines of Harakat Amal, the Amal Movement; and of Hizb Allah, or the Party of God. One of the main points of interest of the Lebanese Civil War which cemented the Shiites as a distinct political and social group was the involvement 
of Imam Musa Sadr (and of Harakat Amal) against the Palestinian armed forces in Lebanon after 1976.

The second chapter will be mainly based on interviews I pursued during my visit to Lebanon in September of 1997, and will examine the provision of social services by the two Shiite parties during and after the Lebanese Civil War. The absence or inadequacy of the provision of social services by the state, prompted the two Shiite parties to offer a vast array of social services which not only provide for the basic needs of the Shiite people, but also provide them with services that improve their socio-political and economic condition. This also plays a significant role in enhancing the political power of the two (especially Hizb Allah).

Finally, the third chapter will examine the socio-political situation of the Maronite community in Lebanon during and after the Civil War. This will be done in order to provide the reader with a larger picture of social politics in Lebanon and a better understanding of the sociopolitical situation of the Shiite community as compared to the Maronite community which constitutes the second largest confessional group in Lebanon today. During the Civil War, the majority of the Maronite community lived under the leadership of the Lebanese Forces (L.F.), the Christian Militia. The L.F. not only organized the community militarily, but also socially. After the end of the civil conflict, the L.F. were dissolved and the creation of the Lebanese Second Republic weakened the political role of the Maronite President in favor of the Sunni Prime Minister and the Shiite President of Parliament. With a vaccum in Maronite political leadership, we witness the role of the Maronite Church as a vehicle for the provision of social services to the Lebanese people in general, but also to the Maronite community in particular. From the traditional role of providing education, the Church has devised a program to provide needy people with basic needs, housing, and medical care. 
Overall, this study will examine the importance of social programs in the promotion of political survival of the different actors. Moreover, the fact that each community takes care of its own does not impede cooperation between them and the never ending pursuit of a dialogue that is the key for peaceful change in Lebanon and elsewhere. 


\section{Chapter I}

History of the Shiites of Lebanon

In 1998, the Shiites of Lebanon are represented politically by two parties who have become an integral part of the Lebanese political scene within the past twenty years. Political scientists investigating Lebanon's politics throughout history naturally recounted the tales of the Muslim Sunnis of Lebanon's littoral during Ottoman times, of the autonomous Druze Emirs, or of the more recent Maronite ascendancy of the first Lebanese Republic (1943-1990). The plight of the Shiite community was seldom examined as the followers of Ali, Prophet Mohammad's nephew and son in law, lived in the shadow of Sunni Islam and inhabited remote areas of Greater Lebanon.

Lebanon, situated at the far east of the Mediterranean littoral, is a country of white mountains and deep valleys gorged with life giving rivers which flow into the sea. This natural setting gave populations of the Middle East a natural refuge from desert areas, but also from persecution. Until the 1960's the Shiites of Lebanon mainly populated two regions of Lebanon: the south of Lebanon, or Jabal Amel, which extends from the border with Israel to the north of the city of Sidon, from the sea to the border with Syria; and the Bekaa Valley. The inhabitants of Jabal Amel are thought to be the descendants of Amila Ben Saba'a of the Qahtan tribe of Yemen, but the erroneous notion of their Persian roots and their belonging to a "schismatic" group of Islam has complicated their relationship with the majority Sunni Muslims of the Arab world.'

'Hicham M. Jaber, Les Chiites du Jabal Amel: Une Dimension Nationale et Regionale, (The Shiites of Jabal Amel: A National and Regional Dimension) (Unpublished Doctoral Dissertation, Universite de Paris Sorbonne Paris-IV, 1997), 6. 
The end of World War I marked the dismemberment of the Ottoman Empire and the territorial division of its lands in the Levant between France and Great Britain. After centuries of growing influence in the region, the European powers had defeated "La Grande Porte" (the Ottoman Sultanate), and France took advantage of this demise to guarantee the Christians of Lebanon an independent state where they would be sheltered and protected from the political hold of the greater Arab Muslim world. The creation of "Le Petit Liban" (Small Lebanon), populated by an overwhelming majority of Christians was abandoned in favor of a more economically viable formula embodied in "le Grand Liban" (Greater Lebanon) which encompassed areas of the South and the Bekaa Valley. These territories infused a higher number of Muslims into the Lebanese state, especially Shiites of the hinterland. The resulting state was thus an amalgamation of people belonging to eighteen different religious communities. The most prominent communities were the Maronites, the Sunni Muslims, and the Shiites who represented $20 \%$ of the total population in Lebanon in 1932.

The National Pact of 1943 symbolizes the Muslim-Christian understanding for the establishment of an independent Lebanese state with a power sharing formula. The Maronites held the presidency while the Sunnis held the Premiership and the Shiites the less influential presidency of the Parliament. The seats of the Parliament were distributed between Christians and Muslims on the basis of a $6 / 5$ ratio. As is well known, this arrangement did not cement a national consensus and its inadequacy reached its full meaning with the conflagration of the Lebanese Civil War (1975-1990).

The Shiites have traditionally been the downtrodden community of Lebanon. Since the creation of the Lebanese state, attention to the regions inhabited by the Shiites has been grossly inadequate. With a state unwilling or unable to provide the necessary services to a growing population, the Shiites 
have understood their need to help themselves. A population that Fouad Ajami qualifies as quiescent "and the bearer of a tradition of lament and submission"2 has re-invented itself under the leadership of Imam Musa Sadr who infused it with a renewed religious consciousness and activism. The years preceding the war and the following ones during the conflict witnessed the creation of different Shiite institutions and parties. Over the years, one can distinguish distinctively an evolution in the self-perception of the Shiite community leading to a political and social mobilization embodied by Harakat Amal and Hizb Allah and resulting in an increased political empowerment within governmental institutions.

In the following pages, I will first briefly review the socio-political history of the Shiite community in Lebanon as well as its socioeconomic situation and its relationship with the few Shiite land owning traditional families. Second, I will relate the importance of Imam Musa Sadr to the formation of a distinct Shiite community consciousness, and the ulterior manifestation of this consciousness through conflict with the Palestinians in Lebanon and through the formation of Shiite parties like Amal and Hizb Allah.

The Shiite population can be traced back to the 7th century AD and the first Arab conquests. Their numbers were very limited and they were mainly concentrated in the Kessrouan region, a Maronite population center today. Shiite immigration would remain important in the following centuries as these minority populations of the Arab world would find refuge from Sunni domination in the mountainous regions of Lebanon. ${ }^{3}$ When the Mamelouks took control of

\footnotetext{
${ }^{2}$ Fouad Ajami, The Vanished Imam: Musa Sadr and the Shiites of Lebanon (Ithaca and London: Cornell University Press, 1986), 51.

${ }^{3}$ Hicham M. Jaber, Les Chiites dans la Vie Politique du Liban avant et apres I'Independance (The Shiites in Lebanese Politics Before and After Independence), Unpublished D.E.A. Thesis, Universite Paris Sorbonne, Paris IV, 1993, 6-8.
} 
Syria, one of their main military expeditions was directed against the Shiite population of Kessrouan which prompted the latter to seek refuge in Baalbeck, the Bekaa Valley, and Jabal Amel in the south of Lebanon. This persecution would not end as it continued with the reign of the Druze Emir Fakhr El Din II who encouraged Maronite peasants to populate Shiite territorial enclaves. With the arrival of the Sunni Ottoman Empire in 1516, Christians and Jews were recognized as different religious communities but the Shiites did not receive the privilege of being recognized as a different and legitimate madhab, or rite; they were classified as part of the whole Muslim society. ${ }^{4}$ It was during that time that the Shiites of Lebanon fostered close ties with Shiite Iran. However, overthrowing the Ottoman order was not in the aim of the impoverished and quiescent population of the Lebanese hinterland. As a matter of fact, the Arab nationalism which endeavored to challenge Ottoman rule was a product of the cities of the Arab world, of Muslim and Christian actors who worked to achieve their political yearnings. ${ }^{5}$

With the coming of the French on the scene, the situation of the Shiites would change. As the Christians were able to persuade the French to create the state of Greater Lebanon which encompassed the territories of Mount Lebanon, Akkar, the Bekaa valley, and Jabal Amel, a large number of Muslims were thereby included within the borders of the country. At that time, the leaders of the Sunni sect were actively pressing the French not to divide the territories under its control into the states of Syria and Lebanon. In order to circumvent their attempts, the French and the Christians encouraged the Shiite community to become an active part of the political debate. It was believed that the Shiites

${ }^{4}$ Majed Halawi, $A$ Lebanon Defied: Musa al-Sadr and the Shia Community (Oxford: Westview Press, 1992), 30-31.

${ }^{5}$ Ajami, The Vanished Imam, 51. 
would rather be part of a multi-confessional society instead of a Sunni dominated Syria where they would probably need to resort to Taqiyya, or dissimulation. The assumptions of the Maronites and of the French were authenticated when the Shiites sided with them for the constitution of an independent Lebanon. ${ }^{6}$ Since the Shiite leadership was constituted by a few feudal families, it was easy for the French and the Maronite to answer their requests for positions in the governmental administration and for good salaries for them and for their followers. In exchange, the traditional Shiite leadership would quell any opposition to French rule that might arise from within their towns and villages.? However, in addition to answering to the needs of the Shiite leadership, the French created new centers of power within the Shiite community. In 1923, the French authorities recognized the rights of the Shiite Ulama (religious leaders) to institute tribunals, and the Shiite madhab was recognized. In 1926, the Shiite leadership was able to obtain a decree from the French governor stating that:

...the Shi'a Muslims in Greater Lebanon form an independent religious community; they are to be judged in matters of personal status according to the principals of the Ja'fari rite (art.1) by their Qadi (art.2) and on appeal by a special Chamber of the Court of Cassation, composed of the President and two assessors to be chosen from among the Shi'a jurists(art.3). ${ }^{8}$

This assured the Shiite community representation in official posts according to the confessional system. Indeed, this decree was the first official document that made it clear that the Shiite community would have a separate identity and would

${ }^{6}$ Moojan Momen, An Introduction to Shii Islam: The History and Doctrines of Twelver Shiism (New Haven and London: Yale University Press, 1985), 264-265. 'Helena Cobban, "The Growth of Shii Power in Lebanon" in Juan R.I. Cole and Nikki R. Keddie, ed., Shiism and Social Protest (New Haven and London: Yale University Press, 1986), 140.

${ }^{8}$ Halawi, A Lebanon Defied, 41. 
not be fused with the Sunni community as was the case under the Ottoman Empire. Finally, in 1936, seven years before Lebanon's independence, the Shiite zuama (traditional leaders) actively supported the concept of Greater Lebanon in opposition to their Sunni counterparts who still espoused an Arab nationalist approach by demanding unity between Lebanon and Syria. ${ }^{9}$ On the 10th of March 1936, the Shiite leadership began stressing its desire "to live with their brethren, members of the different sects, in lasting security and true cooperation for the sake of the 'public good' as members and citizens of Lebanon". ${ }^{10}$ Subsequently, on the 13th of March 1936 the French authorities issued official identity cards to the Shiite population in the same fashion as had been done to the Druze and the Maronites. The Shiite tribunals were officially recognized on the 21 st of October $1936 .{ }^{11}$

These different events can be seen today as stepping stones toward greater state recognition for the Shiite community; but official recognition would not be enough. Socioeconomic change would have to take place in order for the Shiites to empower themselves and to become major players on the Lebanese scene.

When the Ottoman Empire fell in 1918, the Shiites of Lebanon represented at least $17 \%$ of the population. ${ }^{12}$ The majority of this Shiite population was rural and occupied the poorest land. They were ruled by a few rich land-owning families. Most of the peasants cultivated tobacco and cotton, but they were restricted in their activity by the political and economic domination of their zuama who had acquired landed property or had become multazims (tax

'Ibid, 40-41.

${ }^{10} \mathrm{lbid}, 41$.

"Jaber, Les Chiites dans la Vie Politique du Liban Avant et Apres

I'Independance, 15.

${ }^{12}$ Cobban, "The Growth of Shii Power in Lebanon", 139. 
collectors) on behalf of the Ottoman authorities. ${ }^{13}$ The relationship between these landlords and the peasants was organized in part to promote the cultivation of tobacco. Permits to cultivate that crop were given by the "Regie de Tabacs" which was dominated by these powerful landlords. Peasants found it difficult to obtain permits which were mostly given to the zuama who then had the leisure of distributing them for a profit. Consequently, the farmer had no other choice than to submit himself to the rich landlord which reinforced the latter as a traditional political leader. The zuama had achieved an economic grip on the rural world. The cultivation of tobacco presents an important means of understanding the relationship between the Shiite peasant and the few "great families" who lead them. This agricultural activity is also important in order to comprehend the social situation of the Shiite people in Lebanon. Indeed, the tobacco crop requires a great amount of work and attention. It is a year round activity which requires a higher number of workers per plot than any other crop. Peasants usually needed the help of their whole family which hampered schooling for the children. In the Bekaa Valley, the Shiite peasant's crop of choice was until recently hashish. In the 1960's, President Shehab tried to substitute the cultivation of hashish for sunflower, but without success. Instead, the Shiite countrymen resorted to cattle or to a career in the Lebanese Army. ${ }^{14}$

In general, the Shiites were poorer than the rest of the population, had a lower literacy rate, and composed the largest percentage of unskilled laborers

\footnotetext{
${ }^{13}$ Augustus Richard Norton, "Shiism and Social Protest in Lebanon", in Juan R.I. Cole and Nikki R. Keddie, ed., Shiism and Social Protest (New Haven and London: Yale University Press, 1986), 157.

${ }^{14}$ Jaber, Les Chiites dans la Vie Politique du Liban Avant et Apres I'Independance, 24.
} 
and farmers. By the 1960's, they were still underrepresented in government and bureaucratic appointments as well as in the officer corps. ${ }^{15}$

In light of this social and economic situation, many Shiites chose to emigrate in order to escape the hold of the zuama on their lives and to seek social advancement elsewhere. Their primary destination was sub-Saharan Africa where they formed numerous communities while maintaining relations with their villages and hometowns in Lebanon. This emigration became even more important after 1967 when the aggressive Israeli policy in South Lebanon and the lack of protection from the Lebanese Army put immense pressure on the population of the South. The Shiites were, in general terms, tremendously successful in the African countries, and formed a rich Lebanese Diaspora whose distinct goal was to ultimately return to Lebanon with a new found wealth and social status. It was this wealth which supplied the villages with remittances that provided for the schooling of a generation that would break away from the cycle of poverty. ${ }^{16}$

Emigration to the African continent was important, but was not the only destination of the Shiite people. Another destination, closer to home, was Beirut and its suburbs. If the Shiites constituted only $5 \%$ of the population of Beirut at the beginning of the century, they have probably become the most numerous community in the Lebanese capital today. ${ }^{17}$ It is believed that by the early 1980 's, one third of the whole Shiite population of Lebanon had settled in the suburbs of Beirut. It is in and around the cosmopolitan city of Beirut that the Shiite populations from the different remote regions of Lebanon interacted for the first time. These inter community links and contacts have represented a catalyst

${ }^{15}$ Norton, "Shiism and Social Protest in Lebanon", 158.

${ }^{16}$ Ajami, The Vanished Imam, 73.

${ }^{17}$ Momen, Shii Islam, 268. 
to Shiite social change in Lebanon. The Shiites from different regions of Lebanon were now living the same political and social experience in Beirut, and the same effects of urbanization. The interests of the Shiite community could now be fused together forming for the first time a single national Shiite constituency. ${ }^{18}$

In addition, the maintaining of links among Shiite migrants and their villages helped to synthesize the different elements of the community into a single political consciousness. ${ }^{19}$ This consciousness was, in the 1960's, Arab first and Shiite second. The political identity of the Shiite community in Lebanon would be boosted over time by the work of Imam Musa Sadr who challenged the authority of the traditional Shiite leadership, but also by the growing discontent of the Shiites concerning an armed PLO in their midst, and finally by the Islamic Revolution in Iran.

Imam Musa Sadr and the Transformation of Shiite Political Thought

Sayyid Musa Sadr accepted the invitation of the Shiite community after the death of the cleric of South Lebanon, Abd al Hussain Sharaf al Din, who was related to him. The Iranian cleric, eager to be accepted in his new environment, emphasised to his audience that he was the descendent of a Lebanese family:

I am from a family whose origins are to be found in Lebanon: I am a descendant of the Imam Musa Ibn Jafar. My ancestors left Lebanon when Turkish oppression had reached an all time high, when our books were burned and our ulama were killed. My ancestors then left for Iraq and Iran. In the two countries they established a large family. I was born in Iran where my father, Sadr al Din al Sadr, lived and especially established

\footnotetext{
${ }^{18}$ Cobban, "The Growth of Shii Power in Lebanon", 141-142. 19 Jaber, Les Chiites dans la Vie Politique du Liban Avant et Apres I'Independance, 26.
} 
a religious university, in the city of Qom. I first studied in that university, then I obtained a law degree at the University of Teheran. I completed religious education in Najaf, in Iraq. I assumed my religious duties in the south of Lebanon after the death of my relative, Sayyid Abdul Hussein Sharaf al Din. ${ }^{20}$

This passage is taken from a review established in the south of Lebanon showing that Sadr's targeted population was first and foremost the Shiite community of that region. Al Irfan was a cultural review and was founded in the city of Saida by Sheik Ahmed Aref Al-Zein. ${ }^{21}$ In this brief presentation, Sayyid Musa Sadr achieved several goals; he first establishes his lineage and shows his detractors that he comes from an Arab family which left Lebanon because of persecution. His family did not only establish itself in Iran, but in Iraq as well. In fact, one of his most famous relatives was Mohammed Baqer Al Sadr who was executed in Iraq by Saddam Hussein in 1980. He also shows that he is a direct descendent of the seventh Imam of Twelver Shiism, Imam Musa Ibn Jafar, which connects him directly to the family of the Prophet. Finally, his studies show to the conservatives that he received a serious religious education in Qom, a center in Islamic learning; but he also shows that he is a modern man having studied law at the University of Teheran. This Iranian cleric was thus much more than just another religious personality; he was a high profile personality who had to leave his native country populated by a majority of Shiites to settle in the hinterland of Lebanon among a poor and politically weak population. Whether he thought of his new responsibilities as a mammoth undertaking, a challenge of Herculean proportions, he nonetheless endeavored actively to better the situation of his people within the framework of the Lebanese system. He understood the dynamics and the uniqueness of a confessional Lebanese

\footnotetext{
${ }^{20}$ Al Irfan, in Ajami, The Vanished Imam, 32.

${ }^{21}$ Jaber, Les Chiites du Jabal Amel, 347.
} 
society, but he was faced with the problems of a deprived Shiite community which had little consciousness of its political identity.

When Musa Sadr arrived in Lebanon, most of the few politically active Shiites were involved in leftist or Pan Arabist parties. As a Shiite cleric, he knew that Pan Arabism was an ideology of the Sunni Muslim world, and he disliked leftist parties which were secular by nature. His political outlook of a community of the faithful would also have to compete against Nasserism, at least until the aftermath of the Six Day War in 1967. ${ }^{22}$ However, because of its political sensibility, he adopted a pro Palestinian stance, and until the early 1970's supported the actions of the PLO in Lebanon. He believed that the resistance activity of the PLO against the state of Israel was compatible with the sovereignty of Lebanon, and he naturally saw a parallel between the wretched situation of his community and of that of the Palestinian refugees in Lebanon. However, his acceptence of the Palestinian presence and policy in Lebanon would change as the former gained more confidence and power in Lebanon and as PLO actions against Israel would bring more devastating retaliations from the Israelis against the people of the South. ${ }^{23}$ This was not a negation of support to the struggle of the Palestinian people, but a preference for the security of the Lebanese state and the safety of its people, especially the Shiite community of the South. Indeed, Musa Sadr's political orientation was the empowerment of the Shiite community through the creation of institutions for the Shiites and through the strengthening of existing government institutions. He understood that in order to promote better political and social organization in Lebanon, there was a need to work and cooperate with all religious groups of the confessional system. This is

\footnotetext{
${ }^{22}$ Ajami, The Vanished Imam, 113.

${ }^{23}$ lbid. 161-162.
} 
why it is not surprising to see that the Shiite cleric was not only willing, but was also eager to work with all parties including the Christians.

Cooperation between the Maronite Catholics and the Shiites can be seen as a natural phenomenon in Lebanon. Maronite leaders and Musa Sadr shared a strong dislike of Pan Arabism which was largely seen as a Sunni political movement. The Maronites and the Shiites considered themselves as communities with a truly Lebanese national sentiment, and should therefore be able to reach a better understanding in terms of government rule. ${ }^{24}$ Following this logic, Musa Sadr cooperated with President Fouad Shehab who had been in touch with the needs and the aspirations of the Shiite population of different regions of Lebanon and who, as an officer of the Lebanese Army, had traveled to many villages and regions where the Shiites lived, and had grown to understand their plight and their needs. ${ }^{25}$ Shehab and his successor, Charles Helou, launched development schemes in order to build a nation wide economic infrastructure; however, regional events, like the Six Day War and its ramifications, caused the undertaking to have mixed results.

Musa Sadr also worked with Archbishop Gregoire Haddad in a broad based movement to improve the social conditions of the poor of all faiths. The Greek Catholic archbishop was the founder of the Haraka al ljtimaiyya (the Social Movement), and was toiling to empower and aid the inhabitants of the peripheral regions of Lebanon. As Musa Sadr joined the executive council of this non sectarian social movement, he was able to reach a national audience. ${ }^{26}$ In parallel, Musa Sadr's desire to empower the Shiite community as such in Lebanese politics, and within Lebanon's state institutions, was translated into

${ }^{24}$ Ibid. 160.

${ }^{25}$ Cobban, "The Growth of Shii Power in Lebanon", 141

${ }^{26}$ Halawi, A Lebanon Defied, 137. 
his struggle to create a Shiite Higher Council, a body that would finally end the claim of the Sunni Grand Mufti to represent all Muslims in Lebanon. Indeed, the Sunnis as well as the Druze community had a similar religious institution. The Majlis al Shi'a al A'la (the Shiite Higher Council) would enable the Shiite community of Lebanon "to coordinate its affairs, to defend its rights, and to oversee its interests. Such was the inevitable consequence of Lebanon's political configuration with its emphasis on communal particularism". ${ }^{27}$ This is one of the contradictions of the Lebanese experience: even leaders who aim to impact political life on a national level need to resort to, or withdraw into, sectarian politics. The Shiite Higher Council was an important part of Musa Sadr's bid for Shiite community awakening. It was to be an institution of the Lebanese state which would create an additional voice for Shiite politics in the government. Contrary to the Ja'fari Tribunal, constituted by the French authorities in 1923, which handled matters of personal status law, the Shiite Higher Council gave the Shiite religious leaders an officially recognized political voice. $^{28}$

The traditional Shiite leadership, the feudal zuama, were presented with a direct encroachment on their political prerogatives, and parties of the left and the right were confronted with a new actor on the political scene. ${ }^{29}$ The aims of the Council can be summarized as follows:

- To organize the affairs of the community and to work toward improving its socioeconomic standards.

- To carry out [...] responsibilities according to the dictates of scripture.

- To strive for equality and harmony among the Muslims.

${ }^{27}$ lbid. 141.

${ }^{28}$ Norton, Amal and the Shia: Struggle for the Soul of Lebanon (Austin: University of Texas Press, 1987), 44.

${ }^{29}$ Jaber, Les Chiites du Jabal Amel, 402. 
- To cooperate with all Lebanese communities, and to protect the integrity and freedom of the Lebanese nation.

- To fight ignorance, poverty, underdevelopment, social injustice, and moral deterioration.

- To support the Palestinian resistance and to participate effectively with Arab countries for the liberation of Palestine. ${ }^{30}$

These different points summarize perfectly the ideals of Musa Sadr and his political aims. The most important goal is the struggle for the socioeconomic advancement of the Shiite community with an emphasis on the religious aspect of the Council's policy, Islam. This presented a direct challenge to leftist parties since it showed that the institutionalized power of the Shiites would not abide by secular ideologies.

Another central point of the Council was its intent on striving for equality among Muslims; showing that the Shiites' main concern in Lebanon was not the Maronite establishment, but the fear of Sunni ascendancy over the Shiite community. Cooperation with all Lebanese communities and support of the Palestinian cause advance the national character of the Council's program and its Arabic identity. Ten years after his arrival in Lebanon, Imam Musa Sadr had finally entered the main stream political debate. The transformation of the Shiite community was well under way.

From 1967 to Imam Musa Sadr's disappearance in Libya in 1978, the Shia Higher Council achieved several of its goals: it created several cells of religious education, elevated the cultural and technical level of the community, and facilitated the strengthening of the ties of the Shiite community with its Diaspora; above all, the Shia Higher Council institutionalized Shiism in the Lebanese state apparatus. ${ }^{31}$ This was a direct affront to the authority of the traditional Shiite leaders, especially to the Speaker of the House, Kamel El

\footnotetext{
${ }^{30}$ Halawi, A Lebanon Defied, 143.

${ }^{31}$ Jaber, Les Chiites du Jabal Amel, 402.
} 
As'ad. In the 1970's, of the nineteen Shiite representatives in Parliament, nine pledged support to the Speaker and, thus, to the status quo; and thirteen adopted positions similar or complementary to those of the Imam. In 1973, the Shiite Higher Council voted to extend Musa Sadr's presidency of that institution from the original six year term to his sixty-fifth birthday. Kamel El As'ad's attempt to block that vote was successfully circumvented. Slowly but surely, Musa Sadr was gaining ground on the traditional leadership. Nonetheless, in the following years the competition between the two would continue. A by-election for a single seat assembly saw the victory of a Sadr candidate by a two-to-one margin over the candidate supported by Kamel El As'ad. In parallel, El As'ad was able to take the Presidency of Majlis al Janub, the Council [for the Reconstruction] of the South, away from the Imam. This Council had been one of the demands of the Shiite Higher Council as a department that would take care of the socioeconomic problems of the South. ${ }^{32}$

Nonetheless, Imam Musa Sadr continued to strive for reform and for the betterment of the Shiites' situation in Lebanon. In March 1976, Musa Sadr presented a Constitutional Document to President Suleiman Frangiyye and to his Prime Minister al Sulh. The powers of the Maronite President were to be slightly reduced and representation in the Parliament was to become evenly distributed between Muslims and Christians. Moreover, Shiites would be given governmental posts with more importance. The demands were acknowledged positively by the head of state, President Franjiyye; but this possible landmark in peaceful solution to the Lebanese conflict was disrupted by the near collapse of the Christian militia and the entry of the Syrian Army in Lebanon in June 1976. ${ }^{33}$

\footnotetext{
${ }^{32}$ Norton, Amal and the Shia, 44-46.

${ }^{33}$ lbid. 48.
} 
Another central project of Imam Musa Sadr was the creation of Harakat al Mahrumin (the Movement of the Deprived) in 1974, which can be seen as the Shiite version of Archbishop Gregoire Haddad's Social Movement. It was the social hand of the Shiite Higher Council, but a hand immune to the politics of that Council which was composed of the nineteen Shiite deputies in Parliament and many other members who did not necessarily agree with Musa Sadr's ideas. With Harakat al Mahrumin, Sadr was free to pursue his ideas unchallenged. This movement embodied all of Sadr's aspirations in his struggle for his community. He attempted to forge solidarity among Shiites of all social classes, and continued to lobby the government for reforms needed to redress the socioeconomic situation of the Shiites in Lebanon. ${ }^{34}$

At the start of the hostilities in 1975, Harakat al Mahrumin created an armed organization that was called Al Afwaj al-Muqawama al-Lubnaniyya, (the Battalions of the Lebanese Resistance), whose acronyms spelled AMAL, or hope in Arabic. They were initially trained by the Palestinian Fatah organization, but Musa Sadr intended these troops to be used as an auxiliary to the Lebanese Army in the defense of the people of the South. They sided, however, with the PLO and their Lebanese allies in 1975, but abandoned that alliance when the Syrian Army entered Lebanon to restore the status quo. ${ }^{35}$

It is this change in Musa Sadr's policy which transformed the Amal movement into a truly sectarian Shiite movement. In the following pages, I will briefly relate the role of the Palestinian presence in Lebanon in thwarting the Shiite community at the forefront of the Lebanese Civil War. It is the break between the Shiite political agenda and the Palestinian cause-- the latter can

\footnotetext{
${ }^{34}$ Halawi, A Lebanon Defied, 155.

${ }^{35}$ Ajami, The Vanished Imam, 168; and Norton, Amal and the Shia, 48.
} 
also be seen as the Sunni Pan Arab cause-- which cemented the particularistic nature of Shiite politics.

A history of cooperation and solidarity between the two peoples evolved into competition and war resulting in the establishment of Harakat Amal, after Musa Sadr's disappearance, as a strong sectarian actor on the Lebanese national arena.

The Palestinian Equation

Since the civil war of 1958, the Muslims of Lebanon were asking for representation following demographic numbers, and considered the guarantees given the Christians in the National Pact --embodied in the Presidency of the Republic and the $6 / 5$ ratio in the Parliament in favor of the Christian community-as no longer acceptable. The Christian establishment remained generally unyielding fearing Muslim hegemony and the specter of the return of the Dhimmi (protected minority) status for their community. They considered the Palestinian presence in Lebanon, their radicalization, and their increased militarization as a blow to Lebanon's sovereignty and independence, and a threat to their freedom.

On the other hand, the Muslims considered the Palestinians to be Arab brothers in need of support in order to right the wrong that was done to them by the establishment of the state of Israel. The Shiites of Jabal Amel also had a history of economic and social relations with the Palestinians of the Galilee as the two regions were part of the Wilayat of Damascus under the Ottoman Empire. As a matter of fact, Palestine embodied a vital economic space for the people of the South. The colorful souks and bazaars of Nabatiyye, Bint Jbail, and Haifa regularly saw the exchange of transactions and merchandise between the two peoples. This relationship continued even after the collapse of the 
Ottoman Empire and the Syckes Picot agreement which entrusted the territories of Syria and Lebanon to France. With the establishment of the state of Israel, the Shiites of Lebanon found the southern border closed and the Palestinian people taking refuge on their land. ${ }^{36}$ The relationship between the Palestinian refugees and the Shiite population of Lebanon was friendly and peaceful in those days; the Palestinians had been good neighbors, and, at their arrival in Lebanon, offered cheap skilled labor. ${ }^{37}$

The basis of the Palestinian problem in Lebanon rests within the diversity of the Lebanese people both in terms of religious affiliation and in political ideology. The Christians, and especially, the Maronites, saw themselves as a separate part of the Arab world with a separate history. They viewed the Muslim world and its Pan Arabist tendencies with suspicion, and thus protected everything Maronite with great zeal. During the start of the conflict against the Palestinians, they wanted to assert the will and the strength of the state and of the Army, but came to a disagreement with the Sunni establishment who espoused a Pan Arab pro-Palestinian view. The Palestinians "had set out to establish a state within a state in Lebanon. Lebanon, they said, was part of the 'Arab homeland,' and they could not accept restrictions on their right to strike into Israel from Lebanon. The Palestinian cause was an overriding Arab cause. And Lebanon was --in the honest retrospective statement of a Palestinian leader, Shafiq al Hut-- a 'garden without fences.' It had a weak state, a fractured social order, and its feuding sects". ${ }^{38}$

The first Palestinian military bases were formed in 1968; since that time, the Palestinian refugee camps became a seat for social perturbation. They

\footnotetext{
36Jaber, Les Chiites du Jabal Amel, 145. ${ }^{3} \mathrm{l}$ bid, 131.

${ }^{38}$ Ajami, The Vanished Imam, 157.
} 
ceased to be refugees and became instead a factor of instability in Lebanese political life. ${ }^{39}$

With the armed conflict between the PLO and the Israeli Defense Forces raging in the South in the late 1960's, the Shiites found themselves refugees in their own country, as they fled to the suburbs of Beirut. Many of their settlements were mixed or neighbored Palestinian ones. This proximity had the first consequence of fusing the political consciousness of the two deprived peoples, and a sense of solidarity was fostered between them.

In 1973, President Franjiyye used the Lebanese Army to subdue the mounting might of the Palestinian forces; his actions were halted by pressure from Arab governments. From 1975 to 1976, the Christian militias succeeded in ridding their sector of Beirut of all Palestinian camps; the camps of Tal el Zaatar, Jisr el Basha and Dbaye were evacuated, and the whole region under Christian control was rid of the Palestinian presence. ${ }^{40}$ The Palestinian refugees and fighters massed themselves in the camps of Muslim West Beirut: Sabra, Chatila and Bourj al Barajeneh; and in the South around the cities of Tyre and Nabatiyye. ${ }^{41}$

The Shiites, confronted with the notion of a state that did not defend them against Israel fought side by side with Palestinian fighters against Christian forces in the camps of Bourj Hammoud, Nabaa, Haret al Ghawareneh and Karantina. The fall of Nabaa in August of 1976, however, showed a change in Musa Sadr's alignment. Allegations of duplicity followed his change of side from the leftist camp to the Kataeb one (the Christian party). ${ }^{42}$ In the South and in the Beirut area, the Shiites who had joined leftist parties fought and died with the

\footnotetext{
${ }^{39}$ Jaber, Les Chiites du Jabal Amel, 127-128.

${ }^{40}$ lbid. 134.

${ }^{4}$ Ibid.

${ }^{42}$ Norton, Amal and the Shia, 48.
} 
Palestinians. With the Israeli operation of March 1978 (Operation Litani), 285,000 inhabitants of the South, out of the total 445,000 , moved north to seek refuge around the capital. Sixty five thousand of them were Palestinian. ${ }^{43}$ This episode was the breaking point for Musa Sadr and Harakat Amal. From that point on until his disappearance in August 1978, the cleric's earlier admonitions to the Palestinians were transformed into policy. In 1974, Musa Sadr had said that the Shiite people's "sympathy no longer extends to actions which expose our people to additional misery and deprivation". ${ }^{44}$ Starting in 1976, but especially after 1978, the Amal movement would break away from any direct alliance with the Palestinian Fida'iyyin. In addition, it was the Israeli "Operation Peace in Galilee" in 1982 and its aftermath that pushed the Shiite villagers of the South to completely abandon their support for the Palestinian cause and to join a Shiite party who would protect their rights as Shiites and as southerners.

Amal and Musa Sadr had finally won the hearts of the Shiite people. With the flight of the PLO and of the leftist parties from south Lebanon, their recruitment of Shiite fighters suffered; Amal, which was seen by the Israelis as a tacit ally, benefited from this phenomenon. Villagers who did not want to be harassed by the Israelis were quick to inflate the ranks of the Shiite movement. ${ }^{45}$

"Operation Litani" was a tragedy of great proportions to the people of southern Lebanon. More and more, the notion that the Israeli attacks would cease if it were not for the armed presence of the PLO was becoming widespread among the southerners. Moreover, the Shiites realized that with the Palestinian presence in mainly Shiite regions of Lebanon, they were the only ones to sacrifice their security and livelihood for this Arab cause. The Arab

${ }^{43}$ Jaber, Les Chiites du Jabal Amel, (The Shiites of Jabal Amel), 108.

${ }^{44}$ Quoted in Ajami, The Vanished Imam, 162.

${ }^{45}$ Norton, Amal and the Shia, 50. 
world, for its part, only served to " [indulge] the turmoil in Lebanon, [give] the Palestinians rope, [and make] available money and weapons. Its irresponsibility bred an embittered sense of betrayal among the Maronites"46, but also among the Shiites. In 1979, the vice-president of the Shiite Higher Council, al Sheik Mohammed Mehdi Shamseddine said that " the land of the South belongs to the people of the region. Any Arab or international decision contrary to this principle will be assiduously fought against. We are willing to sacrifice everything for the Palestinian cause except our land". ${ }^{47}$ According to the French newspaper, Le Monde, two thirds of the Palestinian forces were back in the South in $1979 .{ }^{48}$

The urbanization of the Shiite community, the political involvement of Musa Sadr, and the destructive presence of the Palestine Liberation Organization in Lebanon, all played an important role in the formation of a Shiite political identity and consciousness. But the hold of the traditional families was still present in Lebanon; the only true deterioration of the authority of the traditional leadership came with the heated events of the civil conflict in Lebanon and the spread of armed groups and militias in the country. ${ }^{49}$ The Shiite militia, Amal, played a small role at the beginning of the hostilities, but became a major player on the Lebanese political and military scene after the disappearance of Musa Sadr in 1978, and the disagreements with the Palestinian armed presence in Lebanon. The new political role of the Shiites in Lebanon would also live through its own radicalization. Catalyzed by the Iranian Islamic Revolution in 1979 , the Shiites of Lebanon would see the creation of new political and armed Shiite groups, like Islamic Amal, and Hizb Allah. In the years between 1978 and 1982, the Shiite political scene would live through an accelerated evolution.

\footnotetext{
${ }^{46}$ Ajami, The Vanished Imam, 161.

${ }^{47}$ Jaber, Les Chiites du Jabal Amel, 115-116.

${ }^{48} \mathrm{lbid} .135$.

${ }^{49}$ Norton, Amal and the Shia, 49.
} 
Amal and its Role

Amal, as a party and as a military organization really developed after the death of Imam Musa Sadr. The Shiite villagers had already supported the Lebanese Army when it clashed with Palestinian fida'iyyin in the South in the early 1970's. The tactical withdrawal of the PLO, in 1978, from the South gave Amal the perfect opportunity to consolidate its forces and recruit more fighters. Musa Sadr's colleague, Sayyid Hussein El Husseini, took the leadership of Amal and operationalized its anti-Palestinian policy. Amal's objectives followed the Shiite villagers need for security by aiming to re-establish the authority of the central government and its institutions, by re-organizing a strong national army, and by restoring Lebanon's sovereignty with the disarming of all militias (including Amal). The struggle for the liberation of Palestine would be supported in Palestine, not in Lebanon..$^{50}$

The Secretary General of Amal, Member of Parliament Sayyid Hussein Al Husseini declared in 1979 that " it [was] time for the Palestinians to understand that it [was] in their own interest to respect the sovereignty of Lebanon and the will of its people". ${ }^{51}$ Later that year, Iran sent Revolutionary Guards to help the PLO in the resistance against the state of Israel. An estimated 300 Iranian soldiers landed in the Syrian capital of Damascus and made their way to Lebanon. It was PLO Chairman Yasser Arafat's way of putting Shiite leaders at odds with their anti-Palestinian policy. At that time, most of the Shiite leaders condemmed the arrival and the use of Iranian troops in Lebanon. The Sheik Mohammed Jawad Mognieh, a Shiite alim spoke about the Palestinian presence in south Lebanon as the "cause of the misfortunes of the inhabitants of the

${ }^{50}$ lbid. 61.

${ }^{51}$ Orient le Jour, 2-6-79. 
South". He also mentioned that the presence of Iranian troops in Lebanon would be useless since they would be under the command of the Palestinian forces and since they would fight the Lebanese and not the Israelis. The power and the reach of the PLO was also eluded to when the Sheik added that he knew perfectly well the risks of voicing such affirmations and the fact that he could lose his life because of them. ${ }^{52}$ Kamel El As'ad, President of the Assembly at the time, thought that the Iranian presence on Lebanese soil would just give Israel an excuse to multiply its attacks on Lebanon and its people. ${ }^{53}$ Overall, this incident showed the PLO's influence in the Arab world since the decision to welcome Iranian troops on Lebanese land did not even go through Lebanese government approval. Harakat Amal's defense of Lebanese sovereignty was once more challenged.

From 1979 to 1982, fighting between the Palestinians and Amal escalated; and Amal's position concerning the deployment of the Lebanese Army over all the Lebanese territory furthered the rift between the Shiite organization and all the other actors of the Lebanese conflict. Indeed, until 1982, Amal saw the Lebanese Army as a vestige of Lebanese legitimacy. ${ }^{54}$ However, Amal sought the establishment of a strong legal government which would make all necessary changes in the power sharing formula of the state; this was an objective the Maronite leadership, for one, could not accept.

Facing the Palestinian threat and needing to survive on the Lebanese political scene, the leaders of Amal sought allies. Sayyid Hussein Al Husseini fostered good relations with Syria even though Hafez el Assad had started to support the PLO after Egypt's signing of peace with Israel in 1979. It is this

\footnotetext{
${ }^{52}$ Le Reveil, 12-8-79.

${ }^{53}$ An Nahar, 10-12-79.

${ }^{54}$ Norton, Amal and the Shia, 67-75.
} 
awkward situation that prompted Hussein Al Husseini to resign from his position as Secretary General; his deputy, Nabih Berri was elected for the leadership of the party in 1980. It is this change in leadership coupled with the Islamic Revolution in Iran which would prompt several members of Amal to leave the organization shortly after; Islamic Amal and Hizb Allah would be the creation of those personalities who did not agree with the new Amal leadership and its policies. ${ }^{55}$

The bloodiest battles against the Palestinians took place between June and September 1980, especially since the question of the implantation of the Palestinians in Lebanon had been raised. Another factor that made it impossible for the two organizations to settle their differences was the belief of Amal leaders and of the Shiite people at large that the Palestinians were the true executioners or kidnappers of the Imam Musa Sadr. ${ }^{56}$

After the 1982 Israeli invasion which crowned the defeat of the PLO and its expulsion from Beirut, Amal took control of the southern region of Lebanon in political and in social terms. In Beirut, Amal confronted the regime of President Amine Gemayyel whose army had attempted to expulse Shiite refugees by force of arms. The intifada of February 1984 was a success for Nabih Berri who defeated the aims and policies of Gemayyel and who, by the same token, won a Ministry seat in the Cabinet. This was exactly one of Amal's weaknesses in the Lebanese quagmire. It fought a state whose institutions it cherished; defeating the Gemayyel regime while preserving the state's integrity would prove to be a tricky undertaking. ${ }^{57}$

55 Jaber, Les Chiites du Jabal Amel, 451-456.

${ }^{56}$ lbid. 457.

${ }^{57}$ Al Watan al Arabi, no. 834, 2-26-93, 5. 
On 19 May 1985, Amal attacked the Palestinian camp of Shatila in the obvious attempt to rid Lebanon of what was left of the Palestinian forces; this war would last two years and would cost the lives of 2,500 Lebanese and Palestinians. ${ }^{58}$

This drain in blood and material did not stop Harakat Amal from continuing to fight on other fronts; in 1985 and in 1987, leftist groups, like the Progressive Socialist Party of Walid Jumblat and the Communist Party, launched an offensive in West Beirut against the Shiite movement who avoided defeat thanks to the intervention of 7,000 Syrian troops. ${ }^{59}$ Berri, who had been residing in Syria for security reasons since 1984 was able to return to Beirut thanks to this Syrian support. This shows the extent of Amal's dependence and reliance on Syria since the disappearence of Imam Musa Sadr. In addition, even though Nabih Berri seemed to be supported and well anchored in his position as Secretary General, he started to lose control over the ranks of the movement.

The numerous wars of Amal caused more Amal officials to abandon the ranks of the movement; among them were high ranking military officials like Hassan Hachem, A'al Hamieh, and Mostapha al Dirani who preferred the more fundamentalist stance of Hizb Allah. The years from 1986 to 1990 were marked by bloody battles between Amal and different organizations including the Palestinians, the PSP, and more importantly, Hizb Allah; the Party of God had successfuly penetrated the ranks of its Shiite competitor and had established its control over the Southern Suburbs of Beirut at the former's expense..$^{60}$

\footnotetext{
${ }^{58}$ Graham Usher, "Hizballah, Syria, and the Lebanese Elections", Journal of Palestine Studies, vol. 26, no.2, (Winter 1997), 62.

${ }^{59}$ Marius Deeb, "Shia Movements in Lebanon: Their Formation, Ideology, Social Basis, and Links with Iran and Syria", Third World Quarterly, vol.10, no.2, (April 1988), 687.

${ }^{60}$ Jaber, Les Chiites du Jabal Amel, 461-462.
} 
It is thus not surprising that when the Civil War ended and the Taef Agreement was accepted, Harakat Amal became, according to certain observers, a movement of recruitment for state institutions. ${ }^{61}$ Indeed, the Taef Agreement, in which Amal leaders had participated in and had accepted, had established a constitutional settlement to the Civil War. This Syrian brokered deal, enabled Amal to shed its military nature and return to a purely political life.

Harakat Amal is a Shiite movement; but faithful to Imam Musa Sadr's legacy, it is a Lebanese nationalistic movement which has the aspiration of representing all the Lebanese people. Like the Imam, Amal was conscious about the need to include all Lebanese in their struggle. Indeed, during the wars that raged between Amal and the Palestinians from 1985 to 1987, the Shiite militia protected the Christian population of the district of Magdouche, in the South. ${ }^{62}$

Amal believes in the unity of the nation and the sovereignty of the state. This stems from the belief that the safety and integrity of the Shiite community in Lebanon is directly connected to the independence of Lebanon. It also exemplifies Amal's continued struggle against al lqta al Siyasi, or political feudalism, embodied in the traditional Shiite leadership of such personalities as Kamel el As'ad. In addition, faithful to the original ideals of Harakat al Mahrumin, the movement puts social progress as part of its priorities. According to the Amal leadership, the Lebanese economy based on services, should be diversified and should favor the creation of factories and productive industries. The banking system based on usury should be replaced by al mudaraba, or a partnership for profit and loss system. ${ }^{63}$

\footnotetext{
${ }^{6}$ Al Watan al Arabi, no. 834, 02-26-93, 8.

62Jaber, Les Chiites du Jabal Amel, 260.

${ }^{63}$ Deeb, "Shia Movements in Lebanon ", 691.
} 
Amal, on the other hand, has fostered close ties to the Syrian regime of Hafez el Assad which could pose "a legion of real and imagined threats to Lebanon's independence". ${ }^{64}$ Berri's hold on power at the head of Amal may even have been a direct consequence of his relations with Damascus; at the Sixth Congress of the Amal movement in April 1986, Berri defeated his two competitors, Hassan Hachem and Daoud Daoud, thanks to Syrian pressures on the 432 delegates. ${ }^{65}$

The Shiite movement has also voiced its rejection of the confessional sectarian politics of Lebanon. Initially, the abolition of sectarian politics might result in the dissolution of the Harakat since it is mainly based on Shiite enrollment; but with Amal officials sustaining their constituency --by using government institutions to provide social services to the Shiite community-- and aiming to operationalize a system of proportional representation, the future of Shiite leaders could be kept safe and successful due to the demographic power of the community. ${ }^{66}$ This option would clearly be to the disadvantage of smaller communities, like the Muslim Sunnis and the Christian Maronites.

At the same time, Amal is facing a mounting competition from another Shiite organization, more sectarian and fundamentalist by nature. Since the beginning of the 1980's Hizb Allah, the Party of God, has challenged Amal leadership in Shiite politics and among the Shiite people of Lebanon.

${ }^{64}$ Norton, Amal and the Shia, 76.

${ }^{65}$ Deeb, "Shia Movements in Lebanon", 687.

${ }^{66}$ Norton, Amal and the Shia, 76-82. 
Hizb Allah, or the Fundamentalist re-Awakening.

Even though Hizb Allah was created in 1978, its actual appearance as a major player on the Lebanese political scene took place after the Israeli invasion of Lebanon. Amal leaders, discontent with the leadership of Nabih Berri, started deserting the party after seeing Lebanon invaded and Beirut occupied by the Israeli enemy. Moreover, Nabih Berri's participation in the National Salvation Committee which brokered an accord between Lebanon and Israel on the $17^{\text {th }}$ of May 1983 outraged many conservative Amal officials ${ }^{67}$; they were ready for a change. Since Hizb Allah started as an ad hoc organization of different armed groups, it is not easy to find an actual founder of the Party. Instead, many names come to light. Hussein Mussawi, left Amal in June of 1982 and created Islamic Amal in the city of Baalbeck in the Bekaa. It is believed that Islamic Amal and Islamic Jihad were the special operations organizations of Hizb Allah, but to venture in those allegations would be of the realm of speculation. Hizb Allah has always had this aura of mystery around it. Journalists and scholars constantly debate the truths and untruths of this organization without ever being sure of the conclusion. In a way, this mystery is needed and still wanted by Hizb Allah officials who are still waging a guerrilla war against Israel in the south of Lebanon. ${ }^{68}$

At its inception, the leadership of Hizb Allah included Shaikh Subhi Tufaili who was the Secretary General of the organization for several years; Shaikh Abbas Musawi, who also became Secretary General of Hizb Allah until he was

${ }^{67}$ Hala Jaber, Hizbollah: Born with a Vengeance (New York: Colombia University Press, 1997), 50.

${ }^{68} \mathrm{Hajj}$ Abou Said Al Khansa, Director of the Office of Public Relations of Hizb Allah. Interview with the author on the "Image of Hizb Allah in the West", Beirut, Lebanon, 9-3-97. 
killed along with his wife, son, and thirteen other people by the Israeli army in February 1992 in Jibchit, a town next to Nabatiyye in the south of Lebanon; Shaikh Ibrahim Amin, and Shaikh Hassan Nasrallah who is the present Secretary General after succeeding to Musawi.

During a speech at the funeral of his predecessor, Shaikh Nasrallah vowed to guide Hizb Allah in its struggle until the "crumbling of Israel". ${ }^{69}$ There are two Hizb Allah organizations: one in Beirut participating in the institutions of the Lebanese state; and the other in the South waging a war against the state of Israel. For this purpose, Hizb Allah receives considerable Iranian support and has pursued a policy of rapprochement to the Amal movement and to Syria. Hizb Allah members recognize that Syria provides an important political cover to their operations. ${ }^{70}$ This domestic peace coupled with Iranian support is what enables Hizb Allah to continue its war against Israel. It is therefore a party that is vulnerable to domestic and international guidelines which are independent of its will.

Hizb Allah's worldview is based upon the movement's theological allegiance to Ayatollah Khomeini, and the ultimate goal of establishing an Islamic state in Lebanon. However, Hizb Allah considers itself as part of the greater Muslim Umma facing the challenges and the hostility of the "West". Western and Eastern countries are seen as tyrannical agents of the United States "trying to distort our reputation and to fabricate lies against us in a malicious attempt to drive a wedge between us and good and downtrodden men..."71 In line with Ayatollah Khomeini's depiction of the United States as the enemy of Islam, Hizb Allah is intent on confronting the "tyranny", and "aggression" of the United States

\footnotetext{
${ }^{69}$ Jaber, Les Chiites du Jabal Amel, 469.

${ }^{7}$ lbid. 474.

${ }^{7}$ See Hizb Allah's Open Letter reprinted in Augustus Richard Norton, Amal and the Shia, 167-87.
} 
and of its allies in the region. ${ }^{72}$ This suspicious and hostile view of the United States and of Israel is to this day the main political focus of Hizb Allah leaders. The United States is seen as a neo-imperialist country which uses the creation of the state of Israel as a destabilizing factor in the region to better control the Muslim world. ${ }^{73}$ Hizb Allah's ideology thus "splits the world into two camps, the exploited and the exploiters." ${ }^{74}$ Subsequently, only the struggle against the "exploiters" through an Islamic revolutionary process will eradicate injustice and deprivation in the Shiite community. Injustice and deprivation are key words in Hizb Allah's political terminology. They can summarize the aims of the Shiite party as the struggle for the betterment of the Shiite community on all levels: political (to eradicate injustice through political and military empowerment), sociological and economic (to eradicate deprivation through social programs). The former explains Hizb Allah's commitment to wage war against the state of Israel in southern Lebanon, and the latter illustrates Hizb Allah's need to provide the Shiites with a vast array of lacking social services.

Hizb Allah's spiritual guide is Ayatollah Muhammad Hussein Fadl Allah. He was born in Najaf, Iraq, in 1935 or 1936 and studied under Ayatollah Abu al Qasim Khu'i. His father was the late Ayatollah Abd al-Ra'uf Fadl Allah from the southern Lebanese village of Aineta. Sayyid Muhammad Hussein Fadl Allah arrived in Lebanon in 1966 and resided in the Nabaa quarters of Christian East Beirut which was seized by the Christian militia in 1976 (as seen earlier). He started his political involvement in the Fall of 1983 becoming very quickly the

72 Ibid.

${ }^{73}$ Hajj Abou Said Al Khansa, Director of the Office of Public Relations of Hizb Allah. Interview with the author "Hizb Allah and the West", Beirut, Lebanon, 9-3-97.

${ }^{74}$ As'ad Aboukhalil, "Ideology and Practice of Hizballah in Lebanon: Islamization of Leninist Organizational Principles" Middle Eastern Studies, Vol.27 (july 1991), 396. 
spiritual guide of Hizb Allah. He has written many books-- among them, Islam and the Theory of Force, Dialogue in the Qur'an, and Meditations on Islamic Political Thought-- and has accorded many interviews to Western journalists in which he appears to be a personality who at least accepts a certain level of compromise. This is why, "in comparison to many of his brother clerics, he does not come off as a fanatic". ${ }^{75}$ What is most important is that Ayatollah Fadl Allah's message is probably the one that influences most the Shiite community of Lebanon today. Even though his self-proclamation as Marja al Taqlid, or a point of reference for emulation, was refused by a large section of the Shiite community ( led by Amal and other clerics) $;{ }^{76}$ it is obvious that he is accepted as such by Hizb Allah leaders, by a wide number of Lebanese Shiites, and by the Arab world.

Ayatollah Fadl Allah believes that the problems of the Middle East and violence in this region are the consequence of the creation of the state of Israel and of the flawed political agenda of the United States. From the injustice made to the Palestinian people, and the nature of certain Arab regimes who support colonialism ( the colonialism of Israel and the United States) flows the state of violence. This colonialism is the cause of injustice, and inequalities which push the deprived to acts of violence and desperation. Fadl Allah thus reaches the conclusion that extremism is not the product of an "Islamic factor", but of a hostile political situation. ${ }^{77}$

If Islam resorts to war, it is in defense of its ideals that are endangered by the policies of the United States and of its ally, Israel. Fadl Allah continues by explaining the nature of Islam as a complete way of life. Islam is not only a

\footnotetext{
${ }^{75}$ Norton, Amal and the Shia, 104.

${ }^{76} \mathrm{Al}$ Sharq Al Awsat, 5-27-96, 5.

${ }^{7}$ Ayatollah Muhammad Hussein Fadl Allah, "Islam and Violence in Political Reality", Middle East Insight, vol IV, no 495, 1986, 4-7.
} 
religion which represents the relationship between God and man, it "has a complete set of laws regulating all individual and communal aspects of life". ${ }^{78}$ For this reason, Islam is not only a religion but an ideology of government; it is, thus, natural that it aims to seize power, like any other ideology. Therefore, Islam does not separate the temporal from the spiritual, and Muslims, wherever they live, must abide by the precepts of Islam. In contrast to Christians, Muslims who do not live in an Islamic state are thus the victims of a psychological dilemma. On the other hand, since Christianity separates the religious and the temporal, Christians do not have the same problem.

Sayyid Fadl Allah's moderate approach can be seen by his rejection of establishing an Islamic Republic by force. It is believed that his refusal to ask for an immediate establishment of an Islamic state in Lebanon led to a cold reception in Iran in February 1985. ${ }^{79}$ This flows from his understanding of Lebanese politics and the nature of the Lebanese society; the diversity of religions and political ideologies in Lebanon render the establishment of an Islamic Republic very difficult and unrealistic for the time being.$^{80}$

Fadl Allah does not pretend to dismiss the idea of a Lebanese Islamic state, but he realizes that its advent needs different domestic and international conditions to appear. What Fadl Allah calls for is the struggle to make the views of Islam prevail through preaching and within the framework of the Lebanese democratic debate. A majority will be needed to accede to the installation of an Islamic Republic in Lebanon. ${ }^{81}$

\footnotetext{
${ }^{78}$ lbid. 8.

${ }^{79}$ Norton, Amal and the Shia, 103-104. ${ }^{80} \mathrm{Hajj}$ Hassan Al Chami, Director of the Office of Social Services of Hizb Allah. Interview with the author on "The Viability of an Islamic Republic in Lebanon", Beirut, Lebanon, 9-17-97.

${ }^{81}$ Fadl Allah, "Islam and Violence in Political Reality", 9-10.
} 
In his book, Meditations on Islamic Political Thought, Fadl Allah relates his views on the acceptance of differing points of view in Islam and on the nature of the Islamic state. Sayyid Fadl Allah writes about the value of freedom of thought in Islam. He concedes that some foukaha (religious scholars) have forbidden Muslims to keep or to read works that go against the truth of the Koranic message; these works, the foukaha suggest, can be deceitful and can lead to perdition, and that's why every Muslim's duty is to oppose such works and strive to destroy them. However, Fadl Allah argues that God has created man in a natural state of freedom. His humanity is his strength, his thought, and his ability to make choices. God wants man to enjoy his freedom which is a vital responsibility to him and which should not harm his life or the life of others. ${ }^{82}$ According to Sayyid Fadl Allah, God has also created men who advance misleading ideas; those are the men who have made the wrong choices in life. But if these men are given the freedom to voice their false ideas, then there will be the possibility to put forth an opposing Islamic thought. This Islamic thought will always vanquish those who seek to be deceitful. ${ }^{83}$

In addition, the Koran itself has eternalized the thoughts of heretics who attacked the Prophet by claiming he was a liar, a priest, or a magician. This shows that the Koran makes space for opposing points of view because it has confidence in the truthfulness of its own message. The Koran, therefore, disposes of the necessary means to counter any conflicting idea. ${ }^{84}$ In a way, it is necessary to give opposing ideas a mode of expression because man is attracted to what is forbidden.

\footnotetext{
${ }^{82}$ Ayatollah Muhammad Hussein Fadl Allah, Ta'milat Fil Fikr Al Siyasi Al Islami, (Meditations on Islamic Political Thought), (Beirut: Kitab Al Tawhid, 1995), 47. ${ }^{83}$ lbid. 50-51.

${ }^{84}$ Ibid. 58.
} 
In the case of the Islamic Republic, however, Sayyid Fadl Allah is clear that parties who advance a different political view than that of the Islamic state cannot be allowed since they aim to replace Islamic authority. Parties who do not believe in the basis of the ideology of the Islamic state should not be given the liberty to act within that state ${ }^{85}$ At the same time, there is a right of criticism within the framework of the Islamic state and its policies. This opposition, however, must obey the legal conditions set in the Shari'a which renders it constructive. It is, thus, not an opposition in the same sense as that of the Western democracies. ${ }^{86}$ This is exactly what the Maronites and many Muslims in Lebanon fear; if, in the future, a Muslim majority votes for the political agenda of Hizb Allah, the creation of an Islamic state would make political parties with differing ideologies unlawful. ${ }^{87}$

Today, Hizb Allah's Secretary General is the charismatic Sayyid Hassan Nasrallah. He has repeatedly underlined the good working relationship between his organization and the Republic of Iran, but has always emphasized Hizb Allah's political independence from the Islamic Republic of Iran. ${ }^{88 .}$

Sayyid Nasrallah has also shown that Hizb Allah's fundamentalist stance can be open to compromise given certain extraordinary conditions. On the night of the 4th of September, 1997, to the morning of the 5th, the Lebanese Army and elements of the Islamic Resistance (composed of Amal and Hizb Allah)

${ }^{85}$ Ibid. 40.

${ }^{86}$ lbid. 35-36.

${ }^{87}$ Abati Boulos Naaman, Head of the Order of Maronite Monks during the Lebanese Civil War. Interview with the author on "Christian-Muslim Understanding", Ghosta, Lebanon, September 1997. Abati Boulos Naaman's order organized the arming of the "Christian Resistance" at the beginning of the hostilities in 1975. Monasteries would also be used as hospitals or arms depots. Today, Abati Naaman is part of Christian delegations which participate in interfaith dialogue; soon after my visit, he was leaving for Jordan for such an event. ${ }^{88}$ Al Hayat, 10-16-97. 
successfuly repulsed an Israeli commando operation in Al Ansariye, killing eleven Israeli soldiers and wounding many others. On September the 12th, 1997, Israeli helicopters attacked positions of the Lebanese Army and of Hizb Allah in Arab Salim, killing six Lebanese soldiers and three Hizb Allah fighters. Sayyid Nasrallah's eighteen year old son, Hadi, was one of them. ${ }^{89}$ Following these events, Sayyid Nasrallah announced that Hizb Allah was creating the "Lebanese Brigades against the Israeli Occupation" which would enable Lebanese citizens of all religious communities to join the war against Israel without having to join the Islamic Resistance per se. This shows that Hizb Allah is attempting to shed its sectarian face to become an organization with a national appeal. ${ }^{90}$

Hizb Allah is therefore a political party with specific aims within the realm of the Lebanese democracy. If it has rejected the immediate establishment of an Islamic Republic in Lebanon, it still labors for its advent. However, Hizb Allah will have to overcome many obstacles. Regardless of the many international obstacles like the Syrian presence in Lebanon, Hizb Allah operates in a country with a large number of non-Muslims. In addition, the Muslim community itself is not homogeneous since it is divided along a Sunni-Shiite divide. Finally, in a country where fundamentalism has not had a long history, Hizb Allah will also have to face and win over a large section of the Shiite community in order to advance its political aims. This is the first step that the fundamentalist party is taking. Besides its military struggle against Israel, Hizb Allah is offering a wide array of public services to the Shiite people. In doing so, it is slowly undermining

\footnotetext{
${ }^{89}$ Jane's International Defense Review, "An Interview with Hizb Allah", October 1997, 5-6; and Daily Star, 11-4-97. For more on Hizb Allah military activity and armament, see Jane's Intelligence Review, "A Bizarre Yet Bloody Conflict Drags On in South Lebanon", October, 1997, 457-461.

${ }^{90} L^{\prime}$ Orient le Jour, 11-4-97; and Daily Star, 11-4-97.
} 
Amal's preeminence. Indeed, since the resolution of the Lebanese conflict, Harakat Amal is in the difficult position of being part of a government judged by most of the population as corrupt and highly inefficient.

The Shiite community's history shows an evident evolution in their political and social consciousness. The Shiites are probably the only community in Lebanon today who were able to rid themselves from the shackles of a society based on a feudal system of patron-client relationships. First, the ascent in power of figures like Imam Musa Sadr, enabled a new class of politicians to take hold of the reins of power in Lebanon. The creation of bodies such as the Shiite Higher Council focused the attention of Shiite leaders on the need to improve the socioeconomic standards of the community and to strive for political, social, and economic justice. This new focus in Shiite social consciousness enabled the creation of movements like Amal and Hizb Allah who enjoy today the following of a Shiite community disappointed by the rhetoric of Pan Arabist and leftist parties. The success of these two Shiite movements is linked to their political and social programs which are directly aimed at improving the political and socioeconomic status of the Shiites in Lebanon. Political and social programs are thus components of the same strategy to promote political survival.

The war being the last blow, the Shiite zuama's political leverage has all but vanished. This is a matter of central importance in Lebanese politics. The Shiites are the only community today who have embarked on this new political road. Both Shiite parties have representatives in the Lebanese Parliament and they are both in clear competition to win the hearts and minds of their Shiite electorate. If any of these two parties' goal is to have a national following and political clout in Lebanon regardless of foreign support, they must first be able to command the support of the Shiite population. Accordingly, Harakat Amal and 
Hizb Allah have come to the forefront of Lebanese politics commanding legitimacy through the extension of public services. 


\section{Chapter II}

Harakat Amal, Hizb Allah, and the Provision of Social Services.

Samir Khalaf's Lebanon's Predicament examines the nature of socioeconomic development in Lebanon. He examines the "developmentalist" and the "dependency" models of social change and advances the idea that Lebanon's case does not fit in any of the two.

Developmentalism is the school of thought which believes that tradition and modernity are inimical and sustain a dichotomous interplay. If modernization is to occur, it will have to erode the traditional norms of the society. On the other hand, the "dependency" model states that the social and economic ills of third world countries are "linked to changes in the international economic system sustained by the forces of capitalist imperialism". ${ }^{91}$ Here, modernity is seen as the aggressor of traditional societies.

Samir Khalaf believes that in Lebanon there exists a dialectic between tradition and modernity "whereby [the two] are allowed to infiltrate and transform each other". ${ }^{92}$ He then examines the interesting examples embodied by Family Firms and Associations in Lebanon and their role in development within what Khalaf calls "an adaptive path to modernity". ${ }^{93}$ Khalaf also believes that "when traditions are distinguished from traditionalism as an ideology, traditional norms or practices are treated more functionally as palliatives or stabilizing agents that

\footnotetext{
${ }^{91}$ Samir Khalaf, Lebanon's Predicament (New York: Columbia University Press:1987), 1-2.

92 lbid. 4.

${ }^{93}$ Ibid. 17.
} 
may prove useful in the solution of current economic and industrial problems; ${ }^{.4}$ however, Samir Khalaf, having written this book in 1987, did not study the development policies of groups like Hizb Allah which became prevalent after 1988.

In fact, Hizb Allah may even challenge Khalaf's claim that traditionalism as an ideology does not allow the modernization and socioeconomic development of a community. Indeed, Hizb Allah's ideology is traditionalist with an emphasis on the return of public and private life to the fundamental teachings of Islam. It is in fact Hizb Allah's traditionalism and the will of its leaders to abide by the social teachings of Islam that makes the movement's social involvement normative.

It is therefore not only Imam Musa Sadr's legacy or the Iranian Islamic Republic's example alone that encourages Hizb Allah to promote a social agenda; it is also and especially part of revolutionary Shiism's norms to promote the socioeconomic development of the Shiite people. Accordingly, Hizb Allah has embarked on an all encompassing social program that touches every aspect of the Shiite community's life. Schools are built to create "a new Shiite man", agricultural projects are undertaken to energize the economy of the hinterland, health care is provided to increase the quality of life, and construction provides shelter and better infrastructure for the poor and the victims of Israeli raids.

Hizb Allah is widely known for its war against Israel, but in the event that peace is reached between the states of Lebanon and Israel Hizb Allah will most likely be disarmed. Would that mean the end of the Shiite movement? Probably not. Indeed, Hizb Allah is not just a military organization. What will make the movement survive politically in the future is its social programs.

${ }^{94}$ Ibid. 146. 
Amal's social services are of a different nature. The secular movement does not have development policies per se, but provides basic needs. In an attempt to uphold Imam Musa Sadr's legacy and the socioeconomic goals of the Shiite Higher Council, Amal claims as its own the projects of the Council of the South which is headed by Amal leader Nabih Berri. But these projects are funded by the government and are usually of grand proportions meaning that they do not always affect the inhabitants of remote areas.

Hilal Khashan's study on the nature of political support and political legitimacy in Lebanon is very interesting at this point. His empirically testable hypothesis advances the notion that fundamentalist groups in Lebanon are considered more legitimate than the national government. This legitimacy flows from ideological affinity and the provision of public services. ${ }^{95}$

What is interesting to underline is the notion that Lebanese Shi'as seem to be more inclined to support national views rather than religious ones in terms of the political organization they would prefer. Fifty two per cent of Shi'as polled in this study believed in Lebanon as an eternal entity compared to 36 per cent who believed in the inevitability of Islamic unity. At the same time, around sixty seven per cent of them do not see the present government as a legitimate one. The responses were almost perfectly divided when they were asked what form of government would be more suitable; forty per cent chose a socialist form of government while forty three believed an Islamic government would hold more legitimacy. It is important to note here that an Islamic government would be the government of a Lebanese state and not the Islamic government of a united Islamic world as understood in the first question. As the numbers show, the

\footnotetext{
${ }^{95} \mathrm{Hilal}$ Khashan, "The Developmental Programs of Islamic Fundamentalist Groups in Lebanon as a Source of popular Legitimation", Indian Journal of Politics, Vol.27, no 3, 4-1993, 1-3.
} 
Shiite population does not favor an Islamic government over a secular one as a matter of principle; opinions are almost equally divided. However, a combination of elements might favor the political ascendancy of Islamic organizations in Lebanon. Indeed, in Khashan's study, forty per cent of Shiites felt that legitimacy flowed from a government's commitment to the Islamic Shari'a or Islamic Law. Furthermore, thirty four per cent felt that a government would be legitimate if it provided comprehensive public services. ${ }^{96}$ Since Islamic organizations are the ones providing most of the public services to the Shiite population (fifty-three per cent of them compensate for the government's shortcomings by resorting to the help of Islamic groups) it is therefore logical that the Shiite population will see these Islamic groups as legitimate. ${ }^{97}$ A political group like Hizb Allah which would theoretically support an Islamic political system in Lebanon and which provides the people with strongly needed social services is clearly in good standing in terms of political legitimacy.

This being said, Lebanese politics are never this simple; other sources estimate that Hizb Allah receives the support of only fifteen per cent of the Shiite public, but it is a determined and well organized minority. "The rest of the Shiites are attached to Lebanon's democratic regime, the respect of its constitution, its national entity, and co-existence with the other Lebanese communities". ${ }^{98}$ Also, with the end of the civil conflict, even traditional leaders, such as Kamel el Asa'd seem to be regaining their popularity. ${ }^{99}$

${ }^{96}$ lbid. 9.

${ }^{97}$ Ibid. 13.

${ }^{98}$ Hicham M. Jaber, Les Chiites du Jabal Amel: Une Dimension Nationale et Regionale, (The Shiites of Jabal Amel: A National and Regional Dimension), Unpublished Doctoral Dissertation, Universite de Paris Sorbonne Paris IV, 1997, 429.

${ }^{99}$ Ahmed Beydoun, Al Intikhabat al Oula Ba'ad al Harb (The First Elections After the War), (Beirut: Dar al Nahar, 1993), 378; 400. 
Nonetheless, the provision of social services is the means that Harakat Amal and Hizb Allah are using to advance the socio-political situation of the Shiite community and, by the same token, to consolidate a constituency.

Amal's social policy was a loosely organized one during the war, and has been linked to government projects since the end of the conflict. Hizb Allah's social organization, however, is strongly organized and gives the fundamentalist party a strong social role in Lebanon.

Harakat Amal, The Office of Health and Social Services. Maktab al Saha wal Khadamat al litimaaiya.

As was discussed in Chapter I, the social aspect of Shiite politics did not start with the Lebanese Civil War but had always been part of the political discourse of Shiite leaders. Imam Musa Sadr stressed the need for more comprehensive social programs directed toward all the downtrodden in Lebanon and especially toward the Shiite community.

The creation of the Shiite Higher Council, the Council of the South, and Harakat al Mahrumin are examples of the importance given to the provision of social services by Shiite leaders like Imam Musa Sadr. Naturally, this interest was inherited by Harakat Amal whose social office was officially opened in 1978, three years after the creation of the party.

Today, the Amal social office is situated in West Beirut close to the Kuwaiti embassy and a United Nations office building. The close ties between Amal and Syrian authorities could explain the Syrian military presence in close proximity of the Amal social office. A check point manned by four untidily dressed Syrian soldiers is situated at an intersection in front of the building. Even though the Syrian Army checkpoints rarely stop anyone nowadays, they serve as a 
constant reminder of Syria's presence in the country and its ultimate security and military abilities in the advent of a given crisis. Basically, the Pax Syriana would be upheld with force of arms if needed.

The office of Hajj Bassem Lamaa, the director of Social Works for Harakat Amal, was situated on the first floor of this building which still bore the marks of the fifteen year Lebanese civil war. The walls of the ground floor were covered with posters of the President of the Assembly, Amal leader Nabih Berri, and of the disappeared Imam Musa Sadr. Inside, there was no electricity in the hallways and staircase. When I reached the first floor clinging to the staircase wall for direction, I was introduced to the Hajj by his veiled secretary. Hajj Bassem is a man in his early forties, casually dressed with white hair and a trimmed white beard. His office was very austere; a small picture of Nabih Berri carefully placed on his desk was competing for space with a variety of paperwork, files and daily newspapers.

"Amal's goal during the civil conflict was to always help the people under its control in partnership with the state. When the state was weak, Amal worked alone", he started. "But Amal's goal was always the strengthening of the state's institutions in order to create a better environment for the people and a better future for the country". The Social involvement of Harakat Amal started with Imam Musa Sadr whose first priority was the South, Akkar, and the Bekaa. A preliminary organization for social works was undertaken under his leadership, but the formation of an organized office for social works took place at the start of the war in 1975. A Jihaz Bachari was organized for most Shiite villages; in each village there would be at least one Amal representative, if not many more, who would help the state and other non-governmental institutions in the distribution of aid and money. In 1984, when the state lost control over many areas in Beirut and elsewhere, Amal became more organized. Its Health and Social Services 
offices were merged, and started offering basic services to people in need as well as infrastructure work. By 1985, the Jihaz al Bachari swelled to four hundred and fifty Amal members who would distribute anything from drinking water to grains, dough, food, and fuel. ${ }^{100}$

In terms of infrastructure work, Harakat Amal would closely work with the state to promote and encourage road repairs and electrical work. Today, Amal whose leader is not only the President of the Assembly but also the director of Majlis al Janoub (The Council [for the Reconstruction] of the South), serves as a social wing of the government catering to the needs of regions populated in majority by Shiites. One problem area that Amal deals with providing electricity to some neighborhoods populated by squatters. The state had cut the electricity to certain areas in Beirut since the people could not pay for it. In turn, the people would rig electrical poles and literally steal the electricity. In this case, Amal served as a mediator between the people and the authorities in the hopes of reaching an agreement. The squatters needed to stay in these buildings until they could be relocated. In order to live comfortably, they needed electricity at a price they could afford. So the state authorities agreed to switch the electricity back on with the understanding that the squatters would stop stealing it and instead start paying for it at a lower price. ${ }^{101}$

Amal members in each neighborhood also survey city streets. Streets which need repairs are hilighted on a map which is sent to the Ministry of Public Works. A network of roads has been planned to reduce the isolation of certain villages, and to encourage economic activity between them. The relationship of

\footnotetext{
${ }^{100} \mathrm{Hajj}$ Bassem Lamaa, Director of the Social Office of Harakat Amal. Interview with the author on "The Early Stages of Amal's Social Work", Beirut, Lebanon, 8-27-97.

${ }^{10}$ Hajj Bassem Lamaa, director of the Social Office of Harakat Amal. Interview with the author on "Amal, the State, and Infrastructure", Beirut, Lebanon, 9-3-97.
} 
Amal and the state has thus grown to become a true partnership. Amal helps the state implement its projects by offering its man power on the ground (distribution of goods), whereas the state may fund projects designed by Amal officials (roads, infrastructure). For example, there has been a great effort to raise the number of schools in the South. The Ministry of the South and Majlis al Janoub has had the task of renovating old schools or building new ones. "Today, there is not one village in the South without a school", proclaims Hajj Bassem. ${ }^{102}$

The project of the "Jisr 7 Chbat", the 7th of February bridge is part of this plan and will cost the Lebanese government an estimated U.S. $\$ 25,000,000$.

There are also two major water dam projects. The Fakhr al Din dam in the region of the Southern city of Nabatiyye will cost an estimated U.S. $\$ 5,000,000$. The Litani River dam is a larger project planned twenty-five years ago, and is meant to use the water of the Litani river to irrigate an area that spans from the Western Bekaa to the Mediterranean city of Kasmiyye. An estimated $70 \%$ of the land surrounding the Litani river is arable land. Today, studies are being undertaken to establish the altitude at which the dam should be built ${ }^{103}$ (Hizb Allah complains that government projects are slow to come to existence).

Amal is also involved in providing health care to the Shite people. The Lebanese Civil War and conflict in the South against Israel created a need for adequate care for injured civilians. A system of ambulances was created to transport victims to nearby hospitals. Poor families were placed into the care of Harakat Amal and their medical expenses were paid by the party. By the end of the war, Amal operated fifty-five welfare centers where poor families could get

102 Ibid.

103 Ibid. 
primary care and medication for free. Health care was also expanded to specialty care; doctors in hospitals were asked by Amal to volunteer their time to offer women's healthcare, pediatrics etc. They would be paid by Amal twenty per cent of their regular fees. To this day, Amal still has agreements with major Beirut hospitals like the American Hospital and the Hotel Dieu. Today, with the reduction of Amal's funding, the number of dispensaries was reduced to thirty three. However, the families of two thousand martyrs are still under the guardianship of the Haraka. Health care, education and money is offered to these families until they can become independent. Each year, a special committee reviews their economic condition to establish their needs. ${ }^{104}$

Hajj Bassem was very clear about the origins of funding for Amal. "Unlike other political parties, Amal is not funded by any foreign government," he said, obviously referring to Hizb Allah's links with Iran. The bulk of Amal's funding is supposed to be generated from the Shiite immigrant communities in Africa and the world. One way that Amal built schools was by asking rich Shiite immigrants to pay for construction work instead of donating cash. A rich donor would thus be able to monitor where his funding is going and have, for example, a school named after him. The state would then be obliged to find appropriate teachers to operate the new establishment.

Another source of funding was the oil refinery of Zahrani which came under the control of Amal during the Civil War. ${ }^{105}$ According to Hajj Bassem, the profits of the company were used to fund Amal's social work and to help the relevant state institutions in any way possible. Finally, Amal would ask businesses in the regions under their control to donate funding for their cause.

${ }^{104} \mathrm{Hajj}$ Bassem Lamaa, interview with the author on "Amal: Healthcare and Education", Beirut, Lebanon, 9-10-97.

${ }^{105}$ lbid 
If Amal succeeded in its aim to become an influential party in government affairs in Lebanon, it has nevertheless lost power on the ground as the state was resuscitated. This shouldn't be a matter of great concern for Amal leaders since the organization's goal has always been to strengthen the Lebanese government's institutions; and since its Secretary General, Nabih Berri, is the President of the Assembly and the President of the Council of the South, or Majlis Al Janoub. However, Harakat Amal is experiencing, today more than ever, an erosion of its popular support. Being part of the government has reduced the energy of Amal's involvement at the grass root level. What Amal claims as its projects are seen by many as the projects of the government's Majlis al Janoub. In addition, the government is seen by many Lebanese as a corrupt and inefficient institution which embezzles funds instead of using them to truly help the needy. That has tarnished Amal's image. Moreover, Hizb Allah's daily operations against Israel and its numerous social programs have made it a powerful military and social force in Lebanon. Today, just like ten years ago, the threat to Amal and its leaders does not come from other sects or a foreign power, it comes from the ascendancy of Hizb Allah.

Hizb Allah's Social Services.

Hizb Allah's social Headquarters are located in the Southern Suburbs of Beirut. Meeting the officials of the fundamentalist party is not an easy task to pursue since it is a para-military organization carrying an on-going guerrilla war against the state of Israel. Many of its members prefer to remain anonymous and view visitors with suspicion.

My first encounter with a Hizb Allah member took place on the 3rd of September, 1997. A long time friend of the family, well placed in one of 
Lebanon's state institutions had kindly arranged the meeting for me. I was escorted by one of his body guards, Fadi, in an unmarked Jeep Grand Cherokee to the heart of the Shiite populated Southern Suburbs of Beirut, famous for its insecurity during the Civil War and a place where many American hostages had been held captive. The Southern Suburbs holds the Headquarters of Hizb Allah and is densely populated by an estimated 500,000 people, almost half of Lebanon's Shiite population. The busy narrow streets, still not equipped with traffic lights, can be treacherous for traffic as cars must maneuver carefully in order to simultaneously avoid the oncoming traffic, the many pot holes and the dense pedestrian population. It was noteworthy to see that even though many women wore the veil, many others did not. This mix of traditional Muslim garb and western attire mingling freely in the busy streets is a trademark of other parts of Beirut, but I did not expect to find this diversity in the heart of Hizb Allah territory. This could show an ability to adapt to the cosmopolitan nature of the Lebanese people, a marked difference from the more rigid policies of the Islamic Republic of Iran.

If the Shiite people of the Southern Suburb seemed to be pursuing their lives routinely, Hizb Allah members are always on the alert. When my driver turned into a dead end street, Maktab al Mukabalat (The Office of Public Relations of Hizb Allah) was on the third floor of a building in the middle of the left side of the street. Before we could find parking, we were approached by a young man who seemed suspicious of our presence. "What are you doing here?" he asked my driver. "We came to visit someone," Fadi replied. "Have you come to visit us?" the man continued. "Yes," replied my driver. "Welcome, we were expecting you," said the man after glancing inside the car at its occupants. 
I climbed up the three flights of stairs and reached Hizb Allah's office. Its entrance bore two doors; the original wooden door, preceded by a massive steal door which remained open during the day. Hajj Abou Said al Khansa is the director of Public Relations for Hizb Allah. ${ }^{106}$ We sat down in a living room with his aide, Hajj Chams. Turkish coffee was politely offered to me, but the mood was a little tense. Hajj Abou Said was, at first, skeptical about my visit and the topic of my research. His suspicions were even more heightened because of my coming from the United States; it seems that American scholars are associated by Hizb Allah officials with the American government whom they see as hostile and ignorant of the "true face" of the Shiite fundamentalist organization. "The Americans have sent many governmental envoys to Lebanon to gather information about us," he started. "Mister Norton spent time in Lebanon, but he wrote mainly about Harakat Amal; he did not write anything interesting about us." I assured Hajj Abou Said that my study would not concentrate on the political or military aspect of Hizb Allah, but on its Social Services in the attempt to show the other face of this organization. "Studies are made for different reasons; their goals are not clear," he quickly replied. At that point, I had the eerie feeling that my trip to Lebanon would not be as fruitful as I would have hoped. The window of opportunity had just closed before my eyes in a matter of seconds. I had exhausted my repertoire of confidence building statements when the suspicious Hajj Abou Said started to talk again. Twenty minutes were spent on political rhetoric, before he embarked on a general overview about the social activities of his Party. "We are known as a military organization which wages a war against the enemy. Our struggle against the Zionist enemy began in 1982. There is no military balance between us, and no state balance in the region, but we have the

\footnotetext{
${ }^{106}$ The initial meeting with Hajj Abou Said AI Khansa director of Public Relations of Hizb Allah, took place in the Southern Suburbs of Beirut, Lebanon, 9-3-97.
} 
will to liberate ourselves and to reestablish our state. The West does not want to bother its ally, Israel."

Hajj Abou Said then continued for almost forty-five minutes relating the various social aspects of Hizb Allah's involvement in Lebanon. "If you need more details," he concluded, "you must understand that we will need more detailed information about you." Needless to say I sent the required information the next day. All I could do at that point was to wait. Two days later, I received a phone call from the office of Hajj Abou Said; I had interviews scheduled with all the directors of Social Works of Hizb Allah. I was relieved to realize that I had just been cleared by Hizb Allah authority to pursue my study. In the next days, I would travel again to the Southern Suburbs of Beirut to meet with the head of Hizb Allah's Social Works, the director of Jihad al Bina' (the Jihad of Construction), the director of education, and the directors of the Islamic Health Institute.

Hizb Allah presents a delicate and frustrating problem to the Israeli Defense Force (Tsahal) which has been involved in fighting a guerrilla war against the soldiers of the Party of God since its withdrawal to South Lebanon in 1985. It has probably been the longest low intensity war in which Tsahal has been uncomfortably entangled. Needless to say that Israeli soldiers would rather be doing tours of duty anywhere else but in South Lebanon. Until recently, the image of Hizb Allah in the world press has therefore been that of a Jihad waging blood thirsty radical Islamic group which is fighting for the destruction of the state of Israel. ${ }^{107}$

${ }^{107}$ Hajj Hassan Al Chami, Director of the Office of Social Works of Hizb Allah. Interview with the author on " The Image of Hizb Allah in the West", Southern Suburbs of Beirut, Lebanon, 9-17-97. 
The head of Social Services for Hizb Allah, Hajj Hussein Al Chami, related to me his experience with a seventy year old American journalist who had come to interview him to, in his own words, "look for the truth about Hizb Allah." Hajj Al Chami who is an eloquent man in his early forties is medium framed with short brown hair, a trimmed reddish beard, and big blue eyes. He met the journalist in the waiting area outside his office and, as is the custom, politely talked to her for ten minutes about her trip to Lebanon and her stay in the country. Finally, the journalist, eager to get on with business, asked to meet Hajj Hachem. "I am Hajj Al Chami," he replied. Suddenly, the woman's eyes opened wide as she slowly stood up in surprise. "I'm sorry," she said slowly still in a dazzled state. "I thought you would be older and would look different... with a turban and a long beard and..." "... and long fangs like a werewolf?..." he continued amusingly.

Images thus shape people's minds and may sometimes distort reality. Hizb Allah has been portrayed as a terrorist organization since its inception in the early eighties; anything positive about the organization has thus been overlooked. ${ }^{108}$

Hizb Allah has, indeed, a side that is not as advertised or investigated by reporters. Since its origins, Hizb Allah has been actively involved in the betterment of the Shiite community in its regions. This has become the hallmark of any Shiite organization who wants to have the support of its people and the laurels of legitimacy bestowed upon it. Hizb Allah leaders understand as well the need to offer the people a wide array of services in regions abandoned by the state in order to provide basic human needs, raise the standard of living and thus enable the people to withstand and support the heavy price of resisting against

\footnotetext{
${ }^{108} \mathrm{lbid}$. Also, on the issue of image, Edward Said gives an interesting account on the way images affect international politics in Covering Islam: How the Media and the Experts Determine How we See the World, (New York: Pantheon Books, 1981).
} 
the destructive attacks of the Israeli forces. ${ }^{109}$ Hizb Allah's social services are therefore not only humanitarian by nature, but political as well. The Shiites need schools to learn, medical care for the sick and the wounded, but also and especially repairs to their homes and neighborhoods caused by Israeli operations which often target the infrastructure of villages and towns of the South in the hopes of turning the people against Hizb Allah's military struggle against Israel. This Israeli policy had turned the Shiite population against the PLO who was launching operations from South Lebanon in the early eighties. ${ }^{110}$ Hizb Allah leaders still remember the warm welcome of many Shiites from the South to the invading Israeli Army in 1982 who at that time was seen as freeing them from the overbearing and destructive presence of PLO fighters in their towns. However, if Hizb Allah has political aims, the humanitarian aspect of the party's social works cannot be discarded. Indeed, the commitment to an honorable cause brings Hizb Allah popularity and legitimacy as well as its own internal efficiency and increased survivability.

Resistance to the enemy created needs among the people of the regions concerned due to the destruction caused by the hostilities. Institutions were needed to take care of the families of the martyrs and the wounded who did not receive any governmental aid. Since the government was weak and paralyzed during the war, the poor segments of the population had needs that were not being met. The most important problems were that of water supply, health care and schools. The Southern Suburb witnessed a vast immigration from areas that were unsafe. Buildings were constructed without permits to house this booming

\footnotetext{
${ }^{109} \mathrm{Hajj}$ Hassan Al Chami, interview with the author on " The Provision of Social Services by Hizb Allah", Southern Suburbs of Beirut, Lebanon, 9-17-97. ${ }^{10}$ Helena Cobban, "The Growth of Shii Power in Lebanon", in R.I. Cole and Nikki R. Keddie, ed., Shiism and Social Protest (New Haven and London: Yale University Press, 1986), 146.
} 
population. These people also needed everything from schools to garbage collection. With the absence of the state, Hizb Allah had to take charge and organize social services. ${ }^{111}$

The regions under continuous fighting like the South needed attention as well. Emigration from those regions caused by the war posed a grave danger to Hizb Allah: the loss of its popular support. That is why Jihad al Bina' is so central in Hizb Allah's social works. Destroyed buildings and roads have to be rebuilt to give an incentive to people to return to their home towns and villages. That is not all. "The Institution of the Martyrs" takes care of the family of the deceased in every aspect. The burial is paid for, and a monthly salary is given to the family. Housing, education and employment are offered until the children of the family reach adulthood. The same is done to the family of the captured and imprisoned Hizb Allah fighters. The International Red Cross is also asked to go visit them on a regular basis. ${ }^{112}$ This commitment by Hizb Allah officials seems to be well appreciated by most Hizb Allah members who are distinguished by their youthfulness and their dedication. One of the employees in the office of Hajj Abou Said Al Khansa excused himself because he was eating in front of me. He explained that if he didn't eat at regular intervals he would have severe stomach pains. I thought him very young for his having ulcers; to that he replied that being held captive ten years in an Israeli prison can have those negative effects. Hizb Allah's social involvement has thus served two missions which center around the good management of resistance activities. One pertains to the rebuilding of homes and infrastructure, and the other to the encouragement of development and of stronger community ties.

\footnotetext{
"'Hajj Hassan Al Chami, interview with the author on "The Provision of Social Services by Hizb Allah", Southern Suburbs of Beirut, Lebanon, 9-17-97. ${ }^{112}$ Ibid.
} 
We are living in a religious society; that is the reason for our duty to help our fellow man. We take this from the Prince of Believers, Imam Ali: 'He who is satiated, while his neighbor is hungry is not a Muslim. Be an enemy to the unjust and a support to the oppressed'. God knows that our society is unfair. He wants us to improve the situation of the poor, and that is true for all religions. There are no games in social relations. Our religious duty is not only met by praying and fasting, but also and especially by helping the poor, the orphans, and all those who are in need. Paying the Khoms (20\% of profits on revenue) and Zakat ( $2.5 \%$ of salary) taxes is part of our religious duty to help the poor. ${ }^{113}$

This shows that the provision of social services is part of Hizb Allah's raison d'etre and is based on normative concerns. In order to achieve the goals mentioned above, Hizb Allah has organized Jihad al Bina', or the Jihad of Construction. This organization is the true embodiment of Hizb Allah's social endeavor, and has played an important role in operationalizing the latter's social rhetoric.

The Jihad of Construction. Jihad al Bina'.

The Jihad of Construction is registered as a charitable foundation at the Ministry of Interior since 1988, and provides basic needs and development projects to areas and villages ignored by the works of the government. ${ }^{14}$ Hajj Kassem Mahmoud Olleik is the General Director of the Jihad of Construction. His office was simple and austere; pictures of Martyrs of Jihad al Bina' were put up on the wall as well as a map of the government's agricultural projects in the Bekaa valley. The Martyrs were workers who had been killed by Israeli attacks as they were rebuilding homes or roads. "We are waging a war against the destruction caused by the Israeli enemy and against the policy of the Hariri

\footnotetext{
${ }^{113}$ lbid.

${ }^{114}$ Daily Star, 4-5-97.
} 
government whose aim is to starve the people in general and the Shiites in particular, and to force them to emigrate and leave their land". ${ }^{115}$

The efforts of the Jihad of Construction are mainly concentrated in the South, but also in the Southern Suburb and in the Bekaa. The South holds the priority because the Israeli attacks are seen by Hizb Allah as a means to undermine their popular support and to force the Shiite population to emigrate. The organization builds all types of establishments. Depending on the need of a community, hospitals, Mosques, and Husseiniyyes --which hold religious, cultural, and social events-- can be built.. ${ }^{116}$

The Repairs to Houses and Villages Damaged by Israeli Attacks

The program of repairs to infrastructure was a direct consequence of Hizb Allah's military involvement against the state of Israel. The Jihad of Construction caters to the double need of support for a population living in a state of war, and support for development purposes to a population in need of public services.

The repairs to homes, roads and businesses is a direct result of Hizb Allah's need to repair the damages of its war against Israel in order to maintain the popular support of the people living in the crossfire. This truly shows that the Hizb Allah leadership has well incorporated the lessons of the PLO war against Israel. It was after 1985 that the villages of the South and the Bekaa started to suffer. Israel had withdrawn its troops from Lebanon, but still occupied a strip of land in the South. Consequently, most of the villages of the South and the Western Bekaa became targets of the Israeli Air Force or artillery following each operation of the Resistance. The damages increased and became unbearable

${ }^{115}$ Hajj Kassem Mahmoud Olleik, General Director of the Jihad of Construction of Hizb Allah. Interview with the author on "The Jihad of Construction's Challenge in Lebanon," Southern Suburbs, Beirut, Lebanon, 9-11-97. ${ }^{116}$ lbid. 
in the Western Bekaa. To this day, the Jihad of Construction has participated in the reconstruction of 15,000 apartments and houses (see Appendix II, 121). The work begins immediately following an attack, and Hizb Allah employs the villagers of the area to rebuild their community's homes. If needed, construction skills are taught. ${ }^{117}$ When the Jihad of Construction was founded in 1988, it had a Herculian task on its hands; many villages of the South had suffered much destruction, and the village of Maydoun, for example, was completely destroyed. After making the necessary studies, the Jihad of Construction sent teams of workers and the material needed to commence the rebuilding and the repair of damaged homes to render them habitable again. That year the re-construction effort repaired 453 houses enabling their inhabitants to return home. ${ }^{118}$

The second era of "great works" was in 1992, a time when, the Lebanese war having ended, Hizb Allah was able to launch more attacks against Israel. That year, the Secretary General of the Islamic organization was killed by Israeli forces, and several villages were destroyed in ensuing attacks. The most severely hit were the villages of Kafra and Yater in Jabal Amel. In order to keep the population of these villages in place, Hizb Allah started to repair the desolate areas forty eight hours after the cease-fire; this time 957 homes were rebuilt or repaired in 1992. ${ }^{119}$

In 1993, Jabal Amel and the Western Bekaa bore the brunt of the Israeli attacks once again, and, once more, thousands of refugees fled to the north; however, with every passing year, the Jihad of Construction was becoming more

${ }^{117}$ Hajj Kassem Mahmoud Olleik, General Director of the Jihad of Construction of Hizb Allah. Interview with the author on "Responding to Israeli Destructions", Southern Suburbs of Beirut, Lebanon, 9-11-97.

118/ad al Oumala': Sit Sanaouat min al Jihad oual Bina', 1988-1994, (The Hand of the Workers: Six years of Struggle and Construction, 1988-1994), Directorate of Information of the Jihad of Construction, March 1994, 28. 119 lbid. 
organized and adept at rebuilding. It put on full alert all its human and material resources to serve the project of "fidelity to the resistance society" under the motto: " together we build... Together, we resist."120 Shortly after the end of the hostilities, the Jihad of Construction opened the roads to destroyed villages and cleared out debris. In the course of a year, 5,000 houses were repaired. ${ }^{121}$

Similarily, after the "Grapes of Wrath", a sixteen day Israeli air and artillery attack in April 1996, the organization spent one million dollars and rebuilt 4,217 houses and 803 shops in 102 towns and villages. ${ }^{122}$ Five thousand villagers were employed; products needed for the reconstruction were bought from the area and local construction companies were hired as well. The ultimate goal was to bring back to life areas hit by the war and to re-energize them economically. ${ }^{123}$

This account of different crises and the effort of rebuilding truly shows the resistance spirit of the Jihad of Construction organization. Its central aim in the regions of resistance to the Israeli forces is to avoid the fate of the repudiated Palestinian Liberation Organization who had launched attacks on Israel from south Lebanon and did not support the population's needs thereafter. The consequence, then, was the rejection of the PLO by the population of the South. Hizb Allah understands the reasons for the plight of the PLO in the hearts of the people of the South; if the resistance to Israel is to continue, Hizb Allah needs to carry on its maintenance of the livelihood of the civilians. The motto, "together we build...together we resist", is a good example of that understanding. If Hizb Allah is to stay in the south of Lebanon, it needs the people of the South to remain in their homes and villages. On the one hand, a deserted southern region may invite Israeli troops to occupy more land; and, on the other hand, any

\footnotetext{
120lbid.

${ }^{121}$ lbid, 29.

${ }^{122}$ Daily Star. 4-5-97.

${ }^{123} \mathrm{Hajj}$ Kassem Mahmoud Olleik, "Responding to Israeli Destructions", 9-11-97.
} 
influx of refugees to Beirut always presents a political time bomb that Hizb Allah would rather not have to deal with. The reconstruction effort thus becomes part of a comprehensive strategy and is indirectly linked to the maintenance of the military and political campaign against Israel.

Nevertheless, the rebuilding of homes is the mere minimum for a community to remain on its land and in its villages. In addition to that, Hizb Allah understands that it needs to create a better community life for the people of the hinterland in order for them to foster a stronger link to the land, and stronger social and religious ties. A sense of community consciousness, the belonging to an Islamic community, is the outcome hoped for by the leaders of the Islamic movement.

Since rebuilding what has been destroyed is the mere minimum, other projects must be undertaken for the community to evolve economically and culturally. This endeavor is embodied in the offering of public services, such as the building of schools, shelters, water lines, sewer systems, and the collection of garbage; the offering of community buildings, such as Mosques and Husseiniyes.

The Building of Mosques and Husseiniyes "He who builds a Mosque, Allah builds him a house in Heaven" (Al Imam Al Sadiq). ${ }^{124}$

To the builders of the Jihad of Construction, the Mosques have a prime role in expanding knowledge, ethics and faith. Since the beginning of the eighties, Muslims have witnessed a religious renaissance which has spread throughout the Muslim world. Their situation started to change in the direction of

${ }^{124} \mathrm{Hizb}$ Allah pamphlet, obtained during the interview. 
faith and the application of the teachings of the Khatem al Anbia', or the "Ultimate of the Prophets". Mosques are also a conduit to stronger religious and social fervor and can create a sense of community belonging and solidarity. Above all, they serve as an Islamic landmark and a means for the propagation of Islam in Lebanon; from 1991 to 1997, the Jihad of Construction built twenty five Mosques and renovated fifteen. ${ }^{25}$

A religious pilgrimage site is planned in Baalbeck for Sayyida Khawla who was the daughter of the Imam al Hussein, the third Shiite Imam. The Jihad of Construction officials prepared a flyer with information concerning these plans, and have distributed them in order to get funding for the project. ${ }^{26}$ The actual pilgrimage site is too small and old. Hizb Allah officials want to transform the present shrine to one of the same scale as the Maqam al Imam Hussein in Karbala (the Shrine of Imam Hussein), and the Maqam al Sayyida Zainab (the Shrine of Sayyida Zainab, the sister of Imam Hussein) in Damascus. All these shrines would be part of the same religious circuit.

Husseiniyes are centers of social and cultural gatherings. Four Husseiniyes were built from 1991 to 1997 and six were renovated. The most important project is the Cultural and Social Center of Khatem Al Anbia' in Bierut which will include a Mosque which can welcome over one thousand worshippers, a Husseiniye for eight hundred and fifty people, a health center comprising four clinics, a cooperative pharmacy, a laboratory, and administrative offices. A cultural center will include all social activities, a library, an Audio Visual library, and a computer training center.

${ }^{125}$ Tisaa Sanaouat min al Aamal wal Aata', (Nine Years of Work and Giving), The Jihad of Construction pamphlet, in the possession of the author.

${ }^{126}$ in the possession of the author. 
The Building and the Fitting Up of Schools

We have seen earlier that Harakat Amal has used state institutions to equip every village with a government funded school. However, Hizb Allah finds the quality of education in those schools to be lacking. For this reason, and perhaps for popularity seeking political reasons, Hizb Allah has set out to build and operate its own school system. The Jihad of Construction has prepared the necessary studies and blueprints for several projects. The organization has overseen these projects' execution in the hopes that they will have an efficient and visible role in the development of the new generations anchored in the learning of sciences and ethics. This is an example of the comprehensive nature of Hizb Allah's development strategy. It shows Hizb Allah's intent to form a new generation of educated youths who will have ideas and goals similar to those of the party, and who could become a new demographic constituency and power base. Also, this shows Hizb Allah's understanding that social development passes through the teaching of modern sciences with, of course, an emphasis on proper Islamic ethical education and behavior. There are eight Hizb Allah schools today, and their construction expands from the South, to the Bekaa, and to Beirut. The most representative of them are:

A- The Imam Al Mahdi Schools

These include the school of Sharkiyeh and the school of Al Majadel in the South; and the school of Ouzaai in Beirut:

1- The School of Sharkiyeh

The school opened its doors in October of 1993. It is a two story building containing thirty seven rooms and classrooms. The built area is of 2,555 sqm on a land of $5,000 \mathrm{sqm}$. Today, the school can receive a student body of 450 , but two additional stories are planned for construction; they would increase the 
number of pupils to 1,350 . To this day, the cost of the entire project has reached the amount of US $\$ 350,000 .{ }^{127}$

2- The Al Majadel School

Just like the school of Sharkiyeh, this school opened its doors in October 1993 and has similar characteristics with a cost of US $\$ 370,000$.

3- the School of Al Ouzaai (see Appendix II, 120)

The school also opened in 1993; it contains 20 rooms and classrooms and has an enrollment of 300 students. The built area is of 960 sqm on a land of 3390 sqm. Its cost was of US $\$ 200,000 .^{128}$

B- The Educational Center of the Martyr Al Oustaz Mohammed Boujaije in Machghara, in the Western Bekaa.

This project is considered to be a complete monument to education. This school is of a particular importance considering that the Western Bekaa region has suffered tremendously from a historical lack of social services; it has also suffered from continuous Israeli attacks. The land was donated by the Islamic Resistance to the people of Machghara.

The school opened its doors in 1992 under the administration of the Comity of Charitable Supply. The building counts nineteen rooms which are divided into nine kindergarten classes and ten primary classes. The school services seven villages which are close to the Israeli occupied zone.

Construction of two additional buildings is proceeding to add elementary and secondary level education. The cost of this project has reached an estimated US $\$ 500,000$ not counting the equipment and administrative costs. ${ }^{129}$

${ }^{127}$ lad al Oumala', 25.

${ }^{128}$ lbid.

${ }^{129}$ Ibid. 26. 
In addition to the construction of new schools, Hizb Allah also has projects of maintenance and repair of existing school buildings. For example, the school of Karha, in the Akkar region of the Northern Bekaa, was built by the population of the village in 1975 , and was suffering of structural damage which was threatening the collapse of the whole building. The school also needed expansion because of the increase in student enrollment. In order to prevent the emigration of the unserviced families, Hizb Allah offered to help, and started work on the expansion, repair, and maintenance of the existing building. The work was achieved with the help of the population showing, once again, the will of Hizb Allah to involve locals in the labor at hand.

The building of these schools offers a testament to the Shiite people that Hizb Allah is not only a military organization, but a social movement. Just like Harakat Amal, which is working within the government institutions, Hizb Allah can offer additional services, especially in areas that Majlis al Janoub has not reached yet. But schools are just a start; water is a topic of great concern for the Shiite population in Lebanon. For the inhabitants of the Southern Suburbs, it is seldom available, and for the Bekaa and the South it is not only a commodity for human consumption, but also a need for irrigation and labor.

The Water Directorate

Water is an essential factor in human life and development, and Lebanon is one of the only countries in the Middle East with plenty of it. The problem resides in the fact that water management in Lebanon is at the same level of development it was prior to the Civil War; in addition, the Lebanese state has never been able to manage its water resources efficiently. Since 1988, the Jihad of Construction has organized itself thoroughly in order to address the needs of the population and the shortcomings of the state. 
The Water Directorate helps the inhabitants by insuring the water supply and repairing water networks and installations. The Directorate works through numerous branches:

1- The branch of hydraulic studies finds the location of underground water.

2- The branch of networks and reservoirs builds water lines and reservoirs to store river and rain water.

3- The branch of maintenance is in charge of needed repairs.

This organization was able to accomplish numerous tasks:

A-The Project of Imam Al Hussein

This project was undertaken to insure the supply of clean drinking water to the village of Lebbaya in the Western Bekaa. The work on the project was accomplished with the help of the local population from 1989 to 1991 . A four hundred meter well was drilled which had an output of 53 cubic meters per hour. The water from this well is pumped to Lebbaya at a flow of 285 cubic meters an hour by a water station containing a 200 cubic meter reservoir. In addition, an electrical station was built to transform an output of 15,000 volts to 220 volts to provide electricity to the village which, thanks to the efforts of the Jihad of Construction is totally self-sufficient in water. ${ }^{130}$

B- The Project of Distribution of Drinking Water in the Southern Suburb of Beirut.

During the last armed conflict in Lebanon in 1990, water and electricity were cut off from the Shiite region. With the financial help of the Islamic Republic of Iran, the Jihad of Construction bought tanker trucks and distributed water. Until 1994, the project supplied an estimated 800 million litres of water for a cost of US $\$ 160,000 .{ }^{131}$ Today, Hizb Allah offers forty-two per cent of the needs

\footnotetext{
${ }^{130} \mathrm{lbid}, 46$.

${ }^{131}$ lbid, 47.
} 
in water of the Southern Suburb. The people have been using water from artesian wells to make up for the water shortage. ${ }^{132}$

C- The Project of Well Drilling

In 1992, the Jihad of Construction completed the work of drilling six wells in six government schools in the Southern Suburbs; the secondary schools of Haret Hraik, Al Ghadir, and Burj al Barajneh. The wells' depth were between twenty seven and sixty two meters, and they were equipped with all the necessary ducts and sanitary equipment.

In addition, the Jihad of Construction organized a program of drilling for remote villages and communities in need. The people of these areas still had to buy water from other towns and transport it on the back of mules for drinking and irrigation purposes. Wells were drilled in twenty-five different projects in all Shiite regions:

- Sixteen of them were drilled in the South

- Two in the Western Bekaa

- Four in the Bekaa

- and two in Akkar, in the North. ${ }^{133}$

These projects are a public service which is central to the development and the betterment of the conditions of life for the Shiite community. In addition, the Jihad of Construction acts as a lobbyist with the government trying to stimulate the interest of the latter in initiating more projects for the downtrodden people of the Shiite community. The Jihad of Construction monitors the few governmental projects planned in the regions where most of the Shiite population lives. For example, governmental water projects, such as wells, water lines, and aqueducts

${ }^{132}$ Hajj Kassem Mahmoud Olleik, General Director of the Jihad of Construction. Interview with the author on "The Social Impact of the Jihad of Construction", Southern Suburbs of Beirut, Lebanon, 9-12-97.

${ }^{133}$ lad al Oumala', 48-49. 
are examined by the Jihad of Construction engineers to make sure that the population will benefit from these works. Indeed, these engineers propose solutions and projects which are believed to be better adapted to a certain region and its population. ${ }^{134}$ The aim of Hizb Allah through this type of endeavor is to make the lives of the people easier and to help them develop economically. However, other services, such as waste management, are also a main concern for Hizb Allah; as late as 1993 , city municipalities did not have the necessary means to meet the needs of a growing population resulting in a catastrophic sanitary situation. To this day, broken sewer lines flooding city streets with detritus are a common occurrence in Beirut. The refuse form fluid and slick streams of highly polluted matter which not only present a health hazard to the population, but also a road hazard to motorists. The warning "slippery when wet" takes a whole new meaning on the roads of Lebanon.

D- The Maintenance of the Sewer System

It was the highly populated Shiite Southern Suburb of Beirut which needed, and still needs, the most work in this area. This neighborhood needed overhauling, a renaissance of sorts, of its whole infrastructure. When it rained, the streets of the Southern Suburbs were literaly transformed into rivers; with bad storms, the flood waters entered into apartments and electricity would be cut. ${ }^{135}$

The Jihad of Construction Water Directorate created a unit composed of specialists for the maintenance of the sewer system. Their mission is to repair all breakdowns in the water networks of the Southern Suburbs and to stop any possibility of contamination which can result in the spread of disease. Another

\footnotetext{
${ }^{134} \mathrm{Hajj}$ Kassem Mahmoud Olleik, General Director of the Jihad of Construction. Interview with the author on "The Social Impact of the Jihad of Construction", Southern Suburbs of Beirut, Lebanon, 9-12-97. ${ }^{135}$ Ibid.
} 
unit's responsibility is to unclog and clean sewers, and to repair their filters and pipelines. ${ }^{136}$

The Water Directorate has become a sort of private consultant which solves the problems of citizens, especially in the winter when sewers breakdown, and, in the summer, when there are water shortages. The life of the population is thus made easier in a time when Lebanon is rebuilding its landscape in Beirut and still fighting a war in the South.

Sewer lines bursting and spilling their filth and putrescence on the streets is not the only health hazard Hizb Allah had to deal with in the Southern Suburbs; five hundred thousand people living there created tons of garbage every day. Municipal workers could not keep up, so the Jihad of Construction created the Committe for Cleanliness.

The Committee for Cleanliness

Garbage accumulating on roadsides presented a danger for public health (the spread of disease) and an eye-sore for the population. The Jihad of Construction bought twelve trucks and employed forty-five people to work in garbage collection and in administrative jobs. Three hundred tons of garbage were collected daily for a period of fifty months, costing the Jihad of Construction an estimated US $\$ 550,000$. The program ended in 1991 when the state started to reclaim its responsibilites; at that time, since they were of no more use, Hizb Allah donated some of its garbage collection material to the city municipality. ${ }^{137}$

This shows that even though Hizb Allah takes upon itself the responsabilities of the state in a benevolent fashion, it does not attempt to

\footnotetext{
${ }^{136}$ lad al Oumala', 51.

${ }^{137} \mathrm{Hajj}$ Kassem Mahmoud Olleik, General Director of the Jihad of Construction. Interview with the author on "The Social Impact of the Jihad of Construction", Southern Suburbs of Beirut, Lebanon, 9-12-97. And lad al Oumala', 52.
} 
replace it. Instead, in concordance with its political criticism of the state, Hizb Allah criticizes the state's socioeconomic policies by identifying their weak points and by working to solve them. For example, the Lebanese state has had a poor agricultural policy for the past forty years. In the early 1960s, President Shehab had attempted to introduce the sunflower to the peasants who were growing contraband hashish, but the program failed. Since then, according to Hizb Allah officials, nothing concrete has been planned. In the early 1990s, the Lebanese state destroyed hashish plantations, but did not offer a substitute. ${ }^{138}$ The Jihad of Construction's Agricultural Commission was founded to study the needs of the Shiite rural regions and propose solutions to the peasents' needs.

The Agricultural Commission

Hizb Allah's main criticism of the state is that it takes care of planning "Pharaonic" projects but does not take into consideration the needs of the small farmer. This is what the Agricultural Commission aims to address in order to help the peasants remain on their land and in their villages. In doing so, the Islamic organization upholds the saying of the Prophet Muhammad (according to the Imam Jaafar AI Sadiq):" For he who loses work, I will find him one". ${ }^{139}$ The Agricultural Commission clearly applies the spirit of this saying by giving help to the farmers who live in the poorest of conditions. The Commission advises them and even offers classes on different agricultural topics, such as the culture of bees, and herd management. ${ }^{40}$ Hizb Allah officials have also mentioned their

${ }^{138} \mathrm{Hajj}$ Kassem Mahmoud Olleik. Interview with the author on "The Jihad of Construction's Challenge in Lebanon", Southern Suburbs of Beirut, 9-11-97. ${ }^{139}$ Author's translation from quote in Mohammad Baqer Al Sadr, Notre Economie, (Our Economy), (Beirut: Dar Al Thakalain, 1995 fr. ed.), 466.

${ }^{140} / a d$ al Oumala', 56. 
cooperation with Christian villages and organizations in terms of agricultural planning.

Another way of helping poor farmers is by supplying them with cheaper products. Usually, agricultural products are imported by wholesalers and sold to retailers who, in turn, sell them at a higher price. To make these products more affordable, the Agricultural Commission has created agricultural cooperatives which sell agricultural products (such as fertilizers, pesticides, seeds, and tools) at a more affordable price; the goals of the cooperatives are not only to offer low prices, but also to supply the villagers with products of good quality. Indeed, the Lebanese market is flooded with products whose sale is forbidden on the international market because they are defective, or poisonous to human beings. The land is studied to understand what kind of fertilizer it needs and what kind of seeds would grow best on it. The Jihad of Construction engineers give advice, teach and help the farmers for free. The ultimate goal is to increase the yield of the crops while simultaneously decreasing the cost of production, and protecting the worker and the environment. The main cooperatives are located in the Bekaa:

1- In the Western Bekaa, in the village of Machghara, the cooperative opened its doors in 1988 and supplies twelve surrounding villages. ${ }^{141}$

2- In the Northern Bekaa, the cooperative services ten villages and five hundred peasants.

3- In the Middle Bekaa, the cooperative started its services in 1990 and supplies 150 agricultural workers from ten different villages who work in vineyards, potato and vegetable fields. This cooperative is located near Lebanese Army

${ }^{14}$ Ibid. 
cooperatives which could mean that the Lebanese Army is supporting the program of Hizb Allah cooperatives. ${ }^{142}$

The Agricultural Commission's aim to increase the profitability of the worker, is also reflected in its partnership with the private international organization, Icarda. Icarda has been able to produce specialties of grain with genetic high yield characteristics. This program also aims at encouraging all farmers -including those who are growing hashish, or who neglect their land- to use these high yield grains. Indeed, according to Islam, ownership is not an individual right, but an operation of delegation since everything belongs to Allah. ${ }^{143}$ Abusing the land or neglecting it could thus be considered a sin and could result in the loss of ownership.

The joint program with Icarda was a success. Initial experiments showed a high rate of profitability with an increase in production of wheat of $190 \%$, of barley of $214 \%$ and of lentils of $90 \%$. If this program is limited to remote villages, it has nonetheless been a success and has given hope to a large number of poor farmers. ${ }^{144}$

The Jihad of Construction's programs seem to be enjoying great success and hold promise for the future. However, Hizb Allah officials feel that they do not receive enough collaboration from the state. Hajj Kassem believes that the Lebanese government, lead by Sunni Prime Minister Rafic Hariri, tends to give priority in its public works to its "allies," clients, or friends. He argues that the poor Shiite masses are being shortchanged. For example, the Shiite population of the Southern Suburb which numbers 500,000 , receives a mere ten per cent of its needed water from the state. The rest has to be furnished by non-state actors

\footnotetext{
${ }^{142}$ lbid. 57.

${ }^{143} \mathrm{Al}$ Sadr, Notre Economie, 121-122.

${ }^{144}$ /ad lal Oumala', (The Hand of the Workers), 60.
} 
like Hizb Allah and others. Since the Southern Suburb does not have municipal services, Jihad al Bina' bought tanker trucks and built water reservoirs to cater to the needs of the population. ${ }^{145}$

Surprisingly, underground aqueducts pass through the Southern Suburb, but are used to supply the construction projects in Downtown Beirut. Rafic Hariri's construction company, Solidere, is in charge of the project. The suspicion that Hizb Allah officials have about Hariri's intent regarding the Shi'as is underlined here and in several other examples. First, the Sunni town of Aramoun which neighbors the Southern Suburb and consists of 30,000 people is supplied with water transported from the town of Damour by the government. That water does not reach the Shiites of the Southern Suburb.

Second, the water of the Kasmiyye river is not used to serve the surrounding Shiite villages, but is instead transported thirty kilometers away to the surroundings of the city of Saida where Hariri and Nabih Berri have bought much land. It is believed that this is done to increase the value of their lands.

Third, the water of the Litani river is transported to Niha, a town neighboring the city of Jezzine where an American company is supposed to build pipelines to Beirut to supply the Solider projects.

Finally, in the south of the Karaoun dam on the Litani river, seven Shiite villages are without proper water supply. The water from the Al Zarka spring is diverted to the town of Jib Janine, thirty kilometers to the north where Prime Minister Rafic Hariri and other Lebanese elite are believed to be building homes. ${ }^{146}$

\footnotetext{
${ }^{145} \mathrm{Hajj}$ Kassem Mahmoud Olleik, General Director of the Jihad of Construction. Interview with the author on "The Social Impact of the Jihad of Construction", Southern Suburbs, Lebanon, 9-12-97. ${ }^{146} \mathrm{Hajj}$ Kassem Mahmoud Olleik, Interview with the author on "The Jihad of Construction's Challenge in Lebanon", Southern Suburbs, Lebanon, 9-11-97.
} 
The suspicions of Hajj Kassem were reconfirmed to me on a Lebanese television program. On the night of September 11th, 1997, a television station aired a political program on which callers could ask questions and voice their complaints to a minister of the Lebanese government. One caller complained that houses of poor people were being destroyed because they had been built without permits while rich people's houses in Jib Janine, built without permits as well, were not being touched.

The Jihad of Construction is Hizb Allah's main embodiement of social services. Its activities range from rebuilding destroyed buildings or antiquated, run-down edifices to creating a better, more livable environment for the Shiite community of the different regions of Lebanon. Hizb Allah's commitment to social services is not only highlighted by the numerous programs of the Jihad of Construction, but also by the multipltiplicity of its social institutions, such as The Islamic Institute for Education and Instruction and The Islamic Health Institute.

The Islamic Institute for Education and Instruction. Al Mou'assasa al Islamiya lil Tarbia wal Taalim

The Institute is in charge of administrating Hizb Allah schools. The schools built by the Jihad of Construction number nine today. They are built in Shiite regions, such as the southern Suburb, and the Bekaa, but the South has the priority since it is a resistance area. Though it is true that every southern village has a school built by the government's Majlis al Janub, Hizb Allah officials claim that the quality of the education in those schools is not appropriate. "The government's schools lack in educational quality; they do not offer teaching of English nor do they provide an adequate moral education. Our schools do," 
says Dr. Bilal Naim who is in charge of the "Imam al Mehdi" schools. The nine schools were built with Iranian financial support. Five of them were built in the South of Lebanon, and four in the Bekaa Valley. All the schools offer Primary and Elementary education, but four out of the nine schools are in the process of offering high school education as well. However, the cost of developing and offering such programs will keep the number of High schools low. There are no Universities yet, but there are plans to build one or two establishments which will offer degrees in Human and Religious Sciences. ${ }^{147}$

Scholarships are given to Shiite children in need regardless of their parents' political affiliation. The aid is mainly offered to the children of poor families, the children of martyrs, and orphans. In the event that there is no more space in a school for a child, Hizb Allah pays for the child's education in the nearest private school.

Financial aid is also given to Shiites who want to attend University. Markaz al Islami lil Tawjih wal Taalim al Aali, the Islamic Center for Guidance and Higher Education, offers loans to students who want to study in a Lebanese University. The loan is reimbursed after graduation with no interest. This program started in 1995 and has helped 200 students to this day. ${ }^{148}$

The school teachers are recruited from the regions where the schools are located. They are not necessarily Hizb Allah members, but must be practicing Muslims. Indeed, not all teachers are Shiites; some are Sunni Muslims. Christian teachers could theoretically be hired as long as they conform to the usages of Hizb Allah. All women school teachers, for example, must be veiled. Even though Hizb Allah is often labeled "fanatic," this shows a certain openness

${ }^{147} \mathrm{Dr}$. Bilal Naim, Director of the Imam Al Mehdi Schools. Interview with the author on "Hizb Allah and Education", Southern Suburbs, Lebanon, 9-15-97. ${ }^{148} \mathrm{lbid}$. 
to non Shiites and a possibility, given the acceptance of certain rules, of working jointly.

The funding for the construction and the operation of these schools are taken from the Khoms tax and from individual and institutional donations. ${ }^{149}$

The Islamic Health Institute, Al Hay'a al Sahiya al Islamiya.

The two representatives I met from The Islamic Health Institute are the only Hizb Allah members who wished to remain anonymous.

The Islamic Health Institute concentrates on improving the population's health in order to further their strength and will to support the Resistance against the state of Israel. The origins of the Institute are traced back to the Lebanese Civil War and to the beginning of the Resistance against Israel. When the state was weak and did not have sufficient means to respond to the innumerable emergencies, Hizb Allah, like Harakat Amal, organized itself. At first, ambulances were bought to carry the wounded from remote areas to the hospital. Today they number seventy-five. Medical professionals trained volunteers in order to expand the system, and maps were studied to know every area in need. Soon after, the Islamic Health Institute was created. It operates forty seven primary health care clinics and one hospital in the Southern town of Nabatiyye. It has also at its disposal five modern mobile clinics which cater to the needs of remote villages. Two of these mobile clinics serve the region of the South, while three take care of the Bekaa region. Overall, seventy four villages would have nothing resembling Health care if these clinics did not exist. A

${ }^{149}$ Ibid. 
patient of these clinics is usually charged a symbolic fee of U.S. $\$ 1.50$, but services are free for those who cannot afford that amount of money.

In April of 1996, during the sixteen days of Israeli raids, the Islamic Health Institute put its 72 ambulances and 217 first-aid men on full alert. Counting the patients treated in mobile clinics and welfare centers, the total amount of people treated neighbored 17,051 patients. ${ }^{150}$

The Islamic Health Institute works with other humanitarian organizations as well. "The Institute should help people of all confessions. We cooperate with Christian organizations because we have the same respect for human life," said my anonymous 'interlocutor'. The Institute has given blood to the International Red Cross who has shipped medical supplies to them. There are also relations with the Young Men's Christian Association (YMCA), Al Shabab al Massihiye, and Harakat Amal. The Institute sometimes coordinates its efforts with those of the Lebanese government and UNICEF who need all the available manpower to achieve their goals on the ground. There are talks with the World Health Organization and the Institute concerning the best way to introduce AIDS education in a religiously conservative society. The Institute's officials are aware of the problem and wish to resolve it, but not using the same methods as in Europe or the United States.

Health care for women and children is one of the Islamic Health Institute's priority. To this day the Institute has vaccinated more than 51,000 children: In 1996 alone, 14,000 children were examined in 97 schools. Today, the most important problem in health care is the lack of medical supplies and of health insurance.

${ }^{150}$ Islamic Health Institute. Tlataachar Aaman min al Aata' (Thirteen Years of Giving Without Limits), brochure in the possession of the author, 9. 
Most of the Institute's employees are volunteers and are not paid. Others are paid a fraction of what they would earn elsewhere. There are programs for doctors who wish to donate one or two days a week for volunteer work.

Funding for the Islamic Health Institute is dependent on individual donations, non governmental organizations, and domestic associations like the Shabab al Masihiye (YMCA).

\section{Conclusion}

Amal and Hizb Allah have thus in different ways achieved political prominence in Lebanon. These two Shiite parties offer the Lebanese political scene different outlooks on the future of the Lebanese state. Amal is part of the Lebanese government and accepts the present distribution of power in state institutions. It supports a secular form of government, the strengthening of state institutions, and the end of sectarianism. On the other hand, Hizb Allah is not part of the government, does not accept the finality of the Lebanese state, would not encourage the strengthening of its present institutions, but rather encourage the application of the Shari'a in one way or another.

It is of consequence that these two parties offer the Shiite people and the Lebanese people as a whole two different political lines. Even though Amal has strong ties to Syria and Hizb Allah to Iran, both parties are strongly nationalistic. One manifests this attachment to Lebanon by striving to empower the Lebanese state and helping the people through government programs, whereas the other manifests patriotism by leading an unremitting resistance to the Israeli occupier and by providing social services that are probably not matched by any other single party in Lebanon.

Amal's participation in the Lebanese government is a mixed blessing. On the one hand, the Shiites have been aspiring to a greater role in Lebanese state 
institutions and Amal has achieved that, especially after the ratification of the Taef Republic, or the Second Lebanese Republic in 1989. On the other hand, being associated with the state can hurt Amal's public legitimacy and reduce its popular support. This is probably the reason that Amal officials to claim the works of Majlis al Janoub (the Council of the South) as the achievements of their party.

Hizb Allah is confronted with a dilemma as well. It is not associated with the government and thus will not be vulnerable to public criticism. In addition, it is able to provide services the people of the South, the Bekaa and the Southern Suburb need. However, although the party enjoys strong support from segments of the population it will remain vulnerable to regional politics, Iranian support, and Syria's good auspices. In addition, if we believe Hilal Khashan's study, if the Lebanese government should cater to the needs of the people and fight corruption, the Shiite population and especially the Lebanese people as a whole will find it more difficult to accept the claim to power of Hizb Allah.

Harakat Amal and Hizb Allah are thus dependent on international factors over which they have little control. This means that their political leverage and survival is hostage to external factors, and could cease to exist given a different international and regional scenario. In addition, as noted earlier, the Hariri government is seen by the Shiites as a Sunni domestic adversary supported politically and financially by Saudi Arabia. Moreover, a Christian observer has noted that the Sunni establishment is weary of the Shiites because of their high birth rate and their alliance with Syria and Iran. He foresees that the next war in Lebanon will be a Sunni versus Shiite one. What the Shiites can achieve in the meantime is to consolidate their positions and try to advance their political and social agendas. It is in fact the commitment to socioeconomic development at the local and national level that can play a decisive role in the political survival of 
Amal and Hizb Allah. However, if these movements have national aspirations, they will have to cooperate with other communities, and a logical choice would be the Maronites.

Some signs of cooperation have already been noted; and as we will see in the following chapter, the Maronites --acting with little or no foreign support-have had a social experience that could be useful to the Shiites. In fact, since the end of the Civil War in 1990 and with the subsequent dissolution of the main Christian party, the Lebanese Forces (L.F.), the Christian community has lost the strongest vehicle of its political outlook. The general Christian perspective is that the Christian parties have lost the war, their political ascendancy in the Lebanese regime, and their political leverage. With the loss of political and military power of the L.F., we can notice a definite concentration of Christian efforts in rebuilding their communities socially and economically. The Maronite Church, for example, believes that if the Maronites strengthen their community by adopting sound development strategies, then political power would be easier to recapture. This underlines Hizb Allah's future ability to cope with a possible loss of political and military power. Indeed, Hizb Allah's development strategy holds the potential to keep the socioeconomically energized Shiite population at the forefront of Lebanese politics.

In addition, it is noticeable that the Shiites and the Maronites have a similar socio-political discourse and ideology in Lebanon today. If the terms "Islam" and "Christianity" are omitted from their speech, they would seem to have similar concerns. The two communities have lived together in Lebanon for over a millenium in the same villages; one cannot find the same mix between the Shiites and the Sunnis, or the Shiites and the Druze.

This means that the cultural, political, and civilizational dialogue between the Maronites and the Shiites has been going on for centuries, and their socio- 
political thinking could have developed the same cognitive structure. 
Chapter III

The Maronite Dimension.

The Maronites reached the mountains of Lebanon in the fifth century AD from Syria. Their name comes from the name of their founder, the monk, Saint Maron. The mountains of Lebanon served as a fortress for many different peoples of the Middle East who sought refuge from persecution. Lebanon was indeed an inviting area. Because of its temperate weather, the inhabitants of the land did not need to struggle against the elements and against disease: Instead, they could lead a healthy life and dedicate their time to work and prayer.

Most Maronites chose to live away from the coastal cities in the comforting isolation of the mountains. Few roads were built through these mountains which facilitated the armed defense of the Maronite territories. This isolation enabled the Maronite people to organize their society around their Churches and monasteries.

During the Crusades, the Knight of Arvieux observed that one could breathe the wind of liberty on the mountains of Lebanon. Natural fortifications and a self sustaining economy made these mountains de facto autonomous territories. Monasteries were model farms, not only sustaining the monks, but also the surrounding villages. The Church organized the life of the family and society. ${ }^{151}$

In recent history, the social organization of the Maronite community has been centered around the Church in time of peace and around a political party in

${ }^{151} \mathrm{Dr}$. Boutros Dib. Professor, Ambassador, and advisor to Presidents Shehab and Sarkis. Interview with the author on "The Socio-political Particularism of the Maronites", Paris, France, 8-15-97. 
time of war. Indeed, during the 1975-1990 Lebanese crisis and the weakening of state institutions, the Christian community was loosely organized around the military and economic program of the Lebanese Forces. Unlike the Amal movement who always tried to rely on state institutions for social funds, the Lebanese Forces tried to create self-sufficient institutions. Their social program is comparable, in many ways, to those of the Shiite organizations.

With the end of the conflict, however, and the dissolution of the Christian Forces, the Church has had to reassert itself as the guarantor of the rights and survival of its community. Some Church leaders view the social undertaking of the Church as a purely charitable work compared to Amal or Hizb Allah's political angle. Nonetheless, it appears that the social involvement of the Maronite Church does contain political motives which are similar to those of Hizb Allah. The officials of the Maronite Social Fund, for example, openly proclaim the political value of their development program.

A parallel could easily be drawn between the prominence and might of the Lebanese Forces of the late eighties and that of today's Hizb Allah. The Lebanese Forces were organized both militarily and socially. The loss of political leverage of the Christian parties at the end of the war has prompted the Maronite Church to concentrate its efforts on development strategies for the survival of its community's presence in Lebanon. This phenomena is an interesting tool to understand the centrality of Hizb Allah's development strategy in promoting its future political survival. 
The Lebanese Forces. Al Kuwat al Lubnaniyya.

In the 1970's, the two largest Christian political parties were Pierre Gemayel's Kataeb and Camille Chamoun's Liberals. Since the arrival of the PLO in Lebanon, the Kataeb had been arming itself to counteract the growing Palestinian military presence. As early as 1969 , skirmishes, such as those of Tal al Zaatar, were taking place between the Christian militia and the PLO. In 1973, President Suleiman Franjiyye called a meeting with Gemayel and Chamoun to inform them that the Lebanese Army would not be able to defend them against the Palestinians. The Arab states would not allow another Black September (King Hussein's elimination of the PLO in Jordan).

Since then, the arming of the Christians took a new direction. In 1975, the Christian militias were still lightly armed and poorly organized, but they undertook the defense of the Christian zones on a limited front. In 1976, when Amal was still a burgeoning military organization, the Christian leaders decided to unite their command to better serve their political and military purpose. Camille Chamoun, Pierre Gemayel, and Suleiman Franjiyye decided to create the Lebanese Front. As the Lebanese state's authority slowly deteriorated, the Lebanese Front quickly established diplomatic relations all around the world and organized the social and economic life of the Christian regions of Lebanon. ${ }^{152}$ The military wing of the Lebanese Front was called the Lebanese Forces. Since the Kataeb made up over $60 \%$ of the total Christian troops, the leadership of the Lebanese Forces naturally fell to a Kataeb member. The Lebanese Forces were headed by the young Bashir Gemayel, Pierre's youngest son. Bashir's second in command was Dany Chamoun, Camille's son. In 1978, the hundred

${ }^{152}$ Karim Pakradouni, La Paix Manquee (Stillborn Peace), (Lebanon: Fiches du Monde Arabe, 2nd ed., 1984), 95, 102. 
day war took place between the Lebanese Forces and the Syrians in the Christian neighborhood of Achrafiyye in Beirut. ${ }^{153}$

This conflict made it necessary for the Christian leaders to organize themselves in order to survive the conflict militarily but also socially. Society had to be organized for war. With the paralysis of governmental institutions, the Lebanese Forces created popular organizations, al Haiat al Chaabiyye. Every day issues of city life had to be dealt with. Here we can distinguish many similarities between the way Amal organized itself and the way the Lebanese Forces organized the society it was controlling.

Garbage collection was organized, road building and even parking areas were built. Contact was established with hospitals in order to facilitate treatment for the wounded. Welfare centers were created in order to offer basic needs and treatment to the wounded in the front areas and in remote regions of the mountains. The old Palestinian refugee camp of Karantina was transformed into a military hospital. The wounded and handicapped of the war were treated in the Beit Shabab institute, and finally a ministry of public works was created. "The Gamma Group" was organized by public workers and company directors whose task was to lead a think-tank on the vital problems of the "Resistance." Problems relating to electricity, gas, fuel and public administration were taken care of by this Gamma group. In parallel, an information network was seen as central to Resistance activities: in 1975, the Kataeb party opened a radio station, the Voice of Lebanon (La Voix du Liban); in 1978, the Lebanese Forces went on the air with the radio of Free Lebanon (Liban Libre), and last, a television station, the LBC was created. ${ }^{154}$

\footnotetext{
${ }^{153}$ Karim Pakradouni, Vice Commander of the Lebanese Forces until 1988. Interview with the author on "The Social organization of the Lebanese Forces", Beirut, Lebanon, 9-14-97. ${ }^{154}$ Ibid.
} 
In order to support this growing public administration, the Lebanese Forces created several sources of funding:

- from 1975 to 1978 the Lebanese Forces installed a tax on imported products arriving at the sea port of Beirut which they took control of. In doing so, they also confiscated all non-Lebanese property in the port.

- Wheat bought by the state was sold to the Lebanese Forces at a lower price. In turn, the wheat was sold on the market at a higher price assuring the Lebanese Forces a reliable source of income.

- In the same fashion as with the wheat, petroleum was bought from the state and sold for a profit by the Lebanese Forces.

- A real estate tax was levied on all real estate transactions in Beirut and Mount Lebanon. ${ }^{155}$

- at the crossing between East and West Beirut, the Lebanese Forces and Harakat Amal had an understanding; products moving across the green line would be taxed only on their way out of a sector by the militia from whose territory the products were leaving. This would protect the trader from double taxing and would encourage commercial activity. ${ }^{156}$ This shows that even during the Civil War, potential enemies would cooperate for economic interest.

- Finally, the marina of the city of Jounieh was turned into a commercial port when the port of Beirut was closed down to commercial traffic.

In 1986, the weakening of the Lebanese pound (from three Pounds a Dollar to 500 Pounds a Dollar) engendered many social problems and poverty. A new $16 \%$ tax was added on movie tickets and restaurant bills, and the Lebanese Forces tried to alleviate the catastrophic situation by creating a social

155Ibid.

${ }^{156}$ General Hicham M. Jaber, Commander of the Greater region of Beirut.

Interview with the author on "Amal and Hizb Allah's Survival", Lebanon, 8-27-97. 
box funded by the fiscal steps discussed earlier. This social box was meant to aid people in great need of assistance. Waves of refugees from war torn areas would be assisted; housing was found for them, and basic needs were supplied. Popular housing was offered to these refugees in Dbaye, and in Mayfouq, in Jbail, where the Palestinian camp used to be. School and food were paid for in the case of the very poor, and financial aid was given to the families of the Martyrs. Finally, public transportation was subsidized in order to enable people to reach their workplace. ${ }^{157}$ These social steps were not only meant to alleviate the suffering of the people, but also to provide the Lebanese Forces --just like Hizb Allah today-- with a source of legitimacy.

To these steps were added the international aid given to the Lebanese Forces and the Christian zone. Militarily, the Lebanese Forces were supported by the state of Israel whose shipment of weapons would be paid in stages; Iraq, Syria's unfriendly neighbor, sent large shipments of weapons and munitions in 1988-89. Socially, non-profit organizations like the Red Cross and Caritas helped in health related issues.

The Maronite Church and the Monasteries played a pivotal part in organizing the resistance of the Lebanese Forces. Aid was awarded financially and in material. Monasteries and convents were open to refugees, and militia fighters as well. Some monasteries were transformed into military caserns. The convent of Kattara was transformed into a Lebanese Forces Headquarters on the Northern front; monks helped to mobilize the population when needed. The monks also operated a hospital in Inaye, Jbail, for war casualties. ${ }^{158}$

${ }^{157}$ Karim Pakradouni, interview with the author on "The Social Organization of the Lebanese Forces", Beirut, Lebanon, 9-14-97.

${ }^{158} \mathrm{Abati}$ Boulos Naaman, Head of the Order of Maronite monks during the Lebanese Civil War. Interview with the author on "The Maronite Church and the Civil War", Ghosta, Lebanon, 9-2-1997. 
The Lebanese Forces, however, were surviving because of the tacit approval of the Lebanese state. In 1987, the state stopped subsidizing wheat and petroleum, so the Lebanese Forces were forced to sell these products at a high price. Combined with the weakening of the Lebanese pound, the situation was becoming untenable. In 1988, the end of Amine Gemayel's presidency gave rise to a constitutional crisis. The Syrians proposed Suleiman Franjiyye as a presidential candidate, but his Christian adversary, Samir Geagea, Commander in Chief of the Lebanese Forces, succeeded in preventing his election. He had convinced numerous members of Parliament not to attend the election session. No compromise was reached, and even Syro-American support to Dahir was not enough to get him elected. Since Gemayel's term was coming to an end, he appointed the General of the Army, Michel Aoun, as Prime minister of a special cabinet to avoid leaving the country without a leader. Aoun enjoyed tremendous support among the Christian population. ${ }^{159}$ His goal was to first unite the Christian forces, and then extend the power of the state over all of Lebanon. He nevertheless, was confronted with two opposition groups:

- Muslim leaders, including Harakat Amal, saw his appointment as a partisan Christian Maronite action, and as a result, a rival government was constituted under the leadership of Prime Minister Selim Huss who demanded constitutional reforms before the election of a President.

- The Lebanese Forces felt threatened by Aoun who undermined Geagea's supremacy in the Christian zones by demanding the end of the levying of taxes

${ }^{159}$ Augustus Richard Norton, "Lebanon After Ta'if: Is the Civil War Over?", Middle East Journal, Vol.45, Summer 1991, 460. Also see Karim Pakradouni, Le Piege: De la Malediction Libanaise a la Guerre du Golfe (The Trap: from the Lebanese Malediction to the Gulf War), (Paris Beirut: Fiches du Monde Arabe, 1991), 2425. 
by the militia authorities. This demand was in part the source of his popularity among an overtaxed Christian population. ${ }^{160}$

In February 1989, Aoun stopped the Lebanese Forces' tax system which was a catalyst in the opening of hostilities between the Army and the Lebanese Forces. Hostilities erupted within the Christian camp for almost a year, from January 1990 to October 1990. After the Syrian brokered Taef agreement was accepted by the Lebanese Parliament in Saudi Arabia, the Lebanese Forces which had accepted and supported the Agreement lost all their institutional power except for their information network, Beit Shabab --an institute for the handicapped--, and a few welfare centers. ${ }^{161}$

This internecine war was the "coup de grace" for the Christian forces who suffered tremendous losses both in casualties and material. This last episode of the Lebanese civil war enabled Syria to increase its role in Lebanon and impose its peace. Militarily and politically, the Christians lost everything; what remained was the Maronite Church, its institutions and its will to heal and help the people organize themselves socially. ${ }^{162}$

After the end of what was known as the fratricidal war between the Army and the Lebanese Forces, the Christian people lost all sense of direction and purpose. The Maronites had held all the key positions in government, the Army, and the Central Bank until the Taef Accord. This was seen by the Christians as a guarantee that they would not be absorbed by the Muslim majority of the Arab world. However, the Taef Accord changed the balance of power in the

\footnotetext{
${ }^{160}$ Karim Pakradouni, interview with the author on "The Social Organization of the Lebanese Forces", Beirut, Lebanon, 9-14-97.

${ }^{161}$ lbid.

${ }^{162}$ Father Louis Smeha, Saint Joseph University. Interview with the author on "The Role of the Maronite Church Since the End of the Civil War", Kaslik, Lebanon, 9-18-97.
} 
Lebanese government to favor the Sunni Prime Minister, and the Shiite President of Parliament. In addition, in this new state, many Christians feel that Syria has acquired too much leverage on Lebanese politics. The notion that elections are fraudulent and that most Christian politicians participating in government are not representative of the true political inkling of the people is widespread. The Syrian omnipresence in Lebanese politics and decision making has encouraged many Christians to withdraw from political life or to emigrate. ${ }^{163}$

When I visited Maronite personalities in Lebanon, the general feeling was that of a defeated population still under the shock of the change in their political and social life. This sense of community depression was not complete, however. The Church's everlasting presence and social involvement was seen as a source of comfort by most, in lieu of the state.

Father Joseph Mwannes is in charge of Communications for the Maronite Church and his thoughts on the situation of the Maronites in Lebanon are generally echoed within the Maronite community:

The problem of the Maronite community is a structural one; the community is a monastic one. The Maronite monks have made a social revolution before the French or the Americans; the Synod of 1736 states: "You will sell the Church's property to teach gratuitously and mandatorily for boys and girls". Each priest has played the role of the adviser, the teacher, and master. He takes care of everything from health care to schooling. The monks have been the founders of the social services of the Lebanese Forces (L.F.). Amal and Hizb Allah start where the Lebanese Forces left off. The L.F. was not a militia, but a resistance movement against the Palestinians, the Syrians, the Libyans and others. For the Shiites there is another way to put it; they provide social services

\footnotetext{
${ }^{163}$ Father Selim Abou, Dean of Saint Joseph University. Interview with the author on "Maronite Fears After Taef", Beirut, Lebanon, 9-16-1997.
} 
for political reasons. The Maronites do not try to overthrow the political and confessional system... because Man has the right to be free. ${ }^{164}$

This passage relates well the concept of political Maronitism in Lebanon; the feelings of some Maronites of Lebanon of being the sole defendors of the country's independence and sovereignty, especially against Arab neighbors who seek political influence in Lebanon. It also underlines the perceived difference between the logic of social involvement of the Maronites and the Shiites. The former seem purely benevolent while the latter are politically motivated. However, the two approaches seem to be closer than acknowledged.

The Guidance of the Vatican

It was to the Church that the responsibility to remedy the situation was given. It had to give confidence back to the Christians of Lebanon, and encourage them not to shun political life and its responsibilities. The Catholic Church's Apostolic Synod was central to the rebuilding of the Christian community in Lebanon. A social and religious renewal was needed to resuscitate a depressed and desperate community. ${ }^{165}$ Among other things, the Apostolic Synod reiterated the Church's attachment to Human Rights defined as the respect of every man but also of every group, because man, who lives in the physical and spiritual realm, transcends all social systems. Indeed, he represents the fundamental value of the social system and should be treated as

${ }^{164}$ Father Joseph Mwannes, in charge of Information for the Maronite Church. Interview with the author on "The Role of the Maronite Church After Taef", Beirut, Lebanon, 9-16-1997.

${ }^{165}$ Father Louis Smeha, interview with the author on "The Role of the Maronite Church since the End of the Civil War", Kaslik, Lebanon, 9-18-97. 
such. ${ }^{166}$ The youth should be taught civic education in order to make them conscious of their responsibilities and to encourage truth, liberty, justice and charity which are the foundations of peace and social fraternity. ${ }^{167}$ The basis of the social thought of the Catholic Church has been defined as follows:

Christ has come to announce the liberation of all men (Ic 4, 16-19; Dt15,15; Is 61,1-2) and to make his truth evident for all men. By the mystery of incarnation he became man. This means that in Jesus is enlightened the mistery of man (329), and that the rights of God and the rights of man are linked, and to violate the rights of one is to violate the rights of the other; on the contrary, to serve man, in a way, is to serve God, because there is no charity that is not accompanied by justice. To serve the poor is to get closer to God. God must be seen in the poor $(330) .{ }^{168}$

The Shiites and the Maronites thus have a similar reason for helping the poor or the oppressed. The Hadith of the Imam Musa Ibn Jaafar states that the Guardian of the people, in case of the insufficiency of the Zakat tax, must help the poor from his own funds (taken from the Khoms tax) until they are satisfied. ${ }^{169}$ Helping the poor and the oppressed is thus a matter of religious duty for both religions.

The Pope argued that a fruitful relationship between Christians and Muslims in Lebanon must begin with a constructive dialogue and a reciprocal acknowledgment. Christians and Muslims are partners in the reconstruction of Lebanon and, already, many instances of inter-faith dialogue have taken place. ${ }^{170}$

It is as a direct result of the Apostolic Synod that social organizations have been created since 1993, especially within the Maronite Church with the

\footnotetext{
${ }^{166}$ Pope John Paul II, "Exhortation Post-Synodale: Une Esperance Nouvelle pour le Liban" (Post-Synodal Exhortation: New Hope for Lebanon), La Documentation Catholique, no 2161, June 1st 1997), 541.

${ }^{167} \mathrm{lbid}$.

168lbid, 542.

${ }_{169}$ Mohammad Baqer Al Sadr, Notre Economie, 484.

${ }^{170}$ Pope John Paul II, "Exhortation Apostolique Post-Synodal", 506.
} 
encouragement of the activities of the Maronite Social Fund. The needs of the community, however, are enormous compared to what the Church and other organizations have been able to create in the past years. Other Church institutions, serving all Lebanese communities and present before the end of the war, are still operating.

Caritas-Liban is the Maronite branch of the Catholic Church's charitable organization which gathers donations from the Lebanese Diaspora and helps the needy, from any religion, in Lebanon. This is what the Apostolic Synod has called for and has hoped to increase; humanitarian aid and social solidarity to foster a renewed feeling of belongingness in a national society that was torn by years of conflict. However, with a reduced political role and an impoverished society, the Maronite Church feels the need to create more institutions which will help the Maronite citizen live a productive life in Lebanon. The goals are clear: fight poverty and help Maronites develop their roots in their country by helping them build their community.

The Maronite Church

The Maronite Church has a history of social involvement for the betterment of the community. If the Shiites started having social programs with the advent of Imam Musa Sadr in Lebanese politics, the Maronite Church has had a history of charity and social works. Monasteries have been a place of religious fervor, but also of community life. Since the fifth century AD in Lebanon, the priest was a teacher in every aspect of life: religious, academic, and professional (artisanal work). Agriculture was also at the center of monastic 
life; monks helped villagers with their crops and taught them new techniques of farming. ${ }^{171}$

Finally, the Synod of the Maronite Church of 1736 was a historical event. Under the rule of the Ottoman Empire, the Synod institutionalized the educational mission of the Church by declaring the need for universal and free education. ${ }^{172}$ The Maronite Church has operated numerous schools and universities, like the Saint Joseph University in Kaslik. Such institutions, make the Maronite social advance on other communities like the Shiites clear. However, the Maronite Church is confronted with a problem that has been increasing since the bloodiest days of the Civil War: the vast exodus of Christians from Lebanon. Several theories have emerged to explain this phenomenon:

- The Maronites who have emigrated during the war are not returning to their native country because they have started new lives in countries where they were easily assimilated; most Christians emigrated to the United States, Australia, Canada, or France where they were able to integrate society and build roots easily. The Shiite emigrants, on the other hand, left Lebanon to settle in countries where they would not be assimilated, African countries in particular. Shiites go to African countries knowing they would ultimately return to their native land. ${ }^{173}$

- The Maronites in particular, as the Middle East Christians in general, are more prone to geographical mobility because of their socio-economic condition. Being part of a rising middle class gives them the will and the ability to emigrate.

${ }^{171}$ Abati Boulos Naaman, interview with the author on "The Social Role of the Maronite Church", Ghosta, Lebanon, 9-2-1997.

${ }^{172}$ Ibid.

${ }^{173}$ General Hicham M. Jaber, interview with the author on " Amal and Hizb Allah's Survival", Lebanon, 9-27-97. 
- The Maronites are not willing to live in a country where they do not feel completely free, and where they see Syria dominating the political landscape.

- The rise of Islamic fundamentalism is another possibility for Christian emigration; associated with the rapid demographic increase of the Muslim population, Islamic Fundamentalism enhances the Christians' fears for their liberties and for their security.

- The economic and social situation of Lebanon does not secure employment, housing, or the promise of a good future for the youth who can find a better situation in Occidental countries.

These reasons make the Maronites feel that they have lost their country. They don't find "their" Lebanon in the agonizing, "oppressed" country it has become.

Overall, this hemorrhage of Lebanese Christians is estimated by an aide of the Maronite Patriarch to have reached 500,000 people in the last 22 years. ${ }^{174}$ In addition, since the end of the war, Christians have not returned in the numbers hoped for. This is a cause of great concern for the Maronite Church who sees its social task in a more pivotal way. The survival of the Maronite community in Lebanon is dependent on the actions of its Church. This is why, in addition to national social programs encompassing all religious sects like Caritas, the Maronite Church has created institutions which would cater directly to the needs of the Maronite community.

In 1988, the same year the Jihad of Construction was created, the Maronite Church organized the Maronite Social Fund. This social organization's leaders are very candid about the aim of their work. In a way very similar to the Jihad of Construction, the Maronite Social Fund is meant to primarily cater to the

\footnotetext{
174"Exodus: Christians of the Arab World Flee their Biblical Homeland", The Independent, September 24th, 1997.
} 
socio-economic needs of the Maronite community, and encourage the community to remain and to build roots in Lebanon.

The Maronite Social Fund. Al Soundouq Al ljtimaai Al Marouni.

The Maronite Social Fund was created on the 25th of June 1987. This Social Fund was created by the Maronite Patriarch, his Bishops, and the superiors of the Monastic Order. The object of the Fund is to aid and give assistance to needy families (with a priority for Maronite families) in matters of food, health, education, and housing. The Fund has its own Board of Directors which includes its founding fathers. Bishop Abou Jaoude was nominated by the Patriarch as the president of the Board. There are nine other members of the Executive Board. The vice-president is always the superior of an Order of priests, and the Director General is a priest. One of the board seats is reserved for a mother superior and the five remaining seats are given to lay people elected by the founding fathers.

The first program was established in 1988 and was called Program 88. It was divided in two sectors of interest:

- Emergency assistance to the needy families and individuals.

- Development projects.

The latter were not feasible during the war because of the on-going armed conflict and because of the importance of the first category. In 1991, a year after the end of the hostilities, the Maronite Social Fund (MSF) alone spent US $\$ 1.5$ million in hospital fees (the MSF would pay $30 \%$ of hospitalization cost), education costs, and assistance to refugees, widows, orphans, and handicapped persons. Anyone who could prove their need would receive assistance. While 
Maronites had the priority for the use of this fund, other confessional communities would also get help. ${ }^{175}$

Until 1992, the MSF was funded by European governments which mainly sent assistance in needed goods. In 1992, for example, the MSF distributed 120 tons of drugs, foodstuffs, clothing, blankets etc. to parishes and welfare centers. But donations ended in 1992 because European countries started giving aid to areas in Africa and in the Balkans. Consequently, due to a shortage of donations, the MSF was faced with the need to raise funds and turned to autofinancing. The Caisse Mutuelle Medico-Social (CMS), or Mutual Medical-Social Fund was created. It receives its funding from individual donors and government donations (the government donates $\$ U S 7,000$ a year); the poorest families can be sponsored by wealthier ones as well. In addition, the money raised is not used directly, but is invested in order to maximize the capital available for the Fund. Poor families who want to join the CMS are asked to subscribe to this medical plan for an amount of money they can afford even if it is a minimal amount. For the third child of a family, subscription is not required and the health expenses of this child and any other additional ones are taken care of by the Maronite Social Fund. This is a way of encouraging people to increase their families in order to make up for the human drain of Maronite emigration. ${ }^{176}$

Today, the budget of the MSF is of $\$ U S 1,000,000$, and that of the CMS is of $\$ \cup S 800,000$. Helping the needy is, nevertheless, not the only program of the Maronite Social Fund. To slow the flow of emigrants, the MSF has embarked on a twenty year project to give their roots back to the Maronites by offering them affordable housing and cost incentives for building homes in their ancestral

\footnotetext{
${ }^{175}$ Father Georges Sakr, Director of the Maronite Social Fund. Interview with the author on "The Maronite Social Fund as a Tool for Community Safeguard", lasou' Al Malek, Lebanon, 9-17-97.

${ }^{176} \mathrm{lbid}$.
} 
villages. This last option would help repopulate the abandoned mountainous regions and re-energize the economy of the periphery of Beirut. This shows the direct involvement of the Maronite Church in social matters which have a political value. ${ }^{177}$

In order to start this program, the Maronite Patriarch Nasrallah Sfeir donated US $\$ 1,000,000$ to the Maronite Social Fund in 1993 in addition to a lot of land of 36,000 sq.m, in Zouk Mosbeh.

The first project of the housing department consists of building 140 apartments divided in two different building sites. The apartments are sold at cost price and the cost of the land is not counted. The first buildings were inaugurated last year, and consisted of a total of sixty apartments which were quickly populated by sixty newly wed Maronite couples. This creates closely knit communities living in the same area. Today, 80 additional apartments are being prepared. It is noteworthy that these apartment buildings do not present the minimum standard of low level income housing; instead, they are fully equipped with modern utilities, landscaping, water wells and a water purifying station. There are two kinds of apartments:

-2 bedrooms cost US $\$ 25,000$ with a down payment of US $\$ 5,000$.

- 3 bedrooms cost US $\$ 30,000$ with a down payment of US $\$ 6,000$. The rest is paid over a period of eight years without interest. These rents are invested to generate money for the next project.

With the enormous amount of demand for affordable housing, the Maronite Social Fund has had to devise a criterion with which to choose the beneficiaries of the housing project. In this instance, the poorest families did not have priority because families needed to be able to cover the cost of purchase.

${ }^{177}$ lbid. 


\section{Criteria:}

- 1st priority; displaced people: squatters, or people living at friends' houses.

- 2nd priority; people living with family members or at their parents' houses.

- 3rd priority; people staying at a friend's empty house.

-4th priority; people renting at an expensive rate with a high occupancy (in some cases people were living in attics), or with poor living conditions (poor insulation, humidity etc.). ${ }^{178}$

For a meager US $\$ 80$ a year, the MSF offers life insurance to the residents of these apartments amounting to US $\$ 35,000$, or about the cost of purchase of an apartment. In the event of the death of the head of the family, natural catastrophe, or fire, the MSF is the beneficiary. The apartment becomes the property of the tenants who also receive the difference between what remained to be paid and the total amount of the life insurance. ${ }^{179}$

In terms of agriculture and work in the villages, the Maronite Social Fund is attempting to encourage Non Governmental Organizations (NGOs) to help. As part of the "building roots" program, the MSF, just like the Agricultural Commission of the Jihad of Construction, is conducting an agricultural and economic investigation in rural regions in order to find the most efficient agricultural activity and the best crop to grow. This would bring people to the land, stop rural exodus and emigration, and regenerate the economy of the village or the region. This program started in Deir al Ahmar which was particularly affected by the end of the war and the interdiction of the growing of marijuana. In these instances, cooperation with other organizations undertaking the same work, such as Hizb Allah, is slow, but existent and friendly. ${ }^{180}$

\footnotetext{
${ }^{178} \mathrm{lbid}$.

${ }^{179} \mathrm{lbid}$.

${ }^{180} \mathrm{lbid}$.
} 
At the village of Ainata in the Bekaa, a French NGO is collaborating with the MSF to study the soil of the region, plant vineyards, and build a winery to produce and export wine.

In yet another village, an Italian NGO donated a bulldozer to work the land and collect rainwater through artificial lakes. ${ }^{181}$

The Maronite Social Fund's programs, though smaller in scale, seem more elaborate than the programs of Harakat Amal or Hizb Allah with an auto funding program and a system of insurance and re-insurance. These attempts at bettering the social situation of the community has made the Maronite Church actively involved in, not only the religious and educational aspect of people's life, but in their economic and communal life as well. While the Maronite Church has historically been involved in its community's life, it has not undertaken a program of this magnitude with a clear policy for the future since the Synod of 1736 . With a changed political situation and a continuing exodus of Middle Eastern Christians from the region, Church leaders just hope it is not too late.

Contrary to the Shiite community, with Harakat Amal disposing of government funds and Hizb Allah disposing of a steady flow of money from the Shiite Khoms tax and Iran, the Maronite Social Fund does not have a steady source of income. Church remittances are distributed to other organizations like Caritas-Liban. The MSF works with a million dollar budget and land donated by the Maronite Patriarch in 1988. This is why the MSF does not, and cannot, cater to the needs of the whole population.

The Maronite Church has demonstrated, through the projects of the Maronite Social Fund, its ability to think and act in socio-political terms. Similar to the programs of Hizb Allah's Jihad of Construction, it has undertaken

${ }^{181}$ Ibid. 
construction work, aid to needy families, schooling programs, healthcare programs, and agricultural programs. The goal of the Maronite and Shiite organizations is to increase the standard of living and the quality of life of their respective population. Hizb Allah and Harakat Amal undertake these projects in order to secure a constituency, while the Maronite Social Fund is attempting to keep the Maronites from emigrating encouraging those who have been displaced by the war to return to their villages. Both strategies either further political power or attempt to salvage it.

However, the Maronites have been slower and weaker in their social mobilization, and do not present a united front. This is why their activities are scattered and smaller in scale. Nevertheless, depending on themselves has given them the advantage of creating new ways and new techniques of providing social services. 


\section{Conclusion}

The Shiite community could not act efficiently in the past because their political, economic, and social demands were frustrated. The arrival of Imam Musa Sadr, a historical figure, gave them morale, hope, and the will to fight and to unite for their rights. Through the creation of official institutions like the Shiite Higher Council and the Council of the South, the Shiite community's identity was crystallized. This new social consciousness was a catalyst to the formation of Shiite movements like Harakat Amal and Hizb Allah. To this day, these two organizations compete to win the allegiance of the Shiite people by providing much needed socioeconomic programs. The success of these parties is therefore linked to political and social programs which are components of the same strategy to promote political survival. This is what is usually overlooked by most scholars when studying Lebanon and the legitimacy of movements like Amal and Hizb Allah. Social policy is at the heart of Shiite politics; one does not survive without the other.

In addition, the impact of such development strategy on the state of Lebanon can be far reaching. Indeed, besides providing political legitimacy to movements like Hizb Allah, such development work can also provide an example for the development programs of the state. Politics based upon socioeconomic development could be the most progressive evolution for the state of Lebanon and a new source of socialization for the Lebanese population as a whole. Moreover, understanding the dynamics and the centrality of social policies could have a hand in changing the perception and the policies of Western countries, especially the United States, when dealing with countries like Lebanon.

Harakat Amal's attempt at providing social services is a legacy of Imam Musa Sadr's ideology. However, Amal's social services do not go beyond the 
provision of basic needs: After the disappearence of Imam Musa Sadr, Harakat Amal turned toward the Syrians and aquired a major political role. The result was that after the Taef Agreement, Amal could say, reminiscent of Louis the fourteenth, "The state is me." Since the early 1990's, Amal attributes to itself all state projects of the South and the Bekaa. These projects take time to undertake, however, and do not have an immediate impact in remote villages.

In the meantime, Hizb Allah appeared on the political scene after 1982, and has been supported and financed by the Islamic Republic of Iran. The Shiites, organized along party lines, and supported by state power have been able to pursue centrally directed goals.

What seems most important is the process of social mobilization as a tool for political power. Hizb Allah is the most energetic movement today in the realm of socioeconomic development. This commitment to a development strategy that covers all aspects of the Shiite community's life is a direct resultant of Hizb Allah's normative guidelines and humanitarian concerns embodied in the Koran and the Hadith. In addition, the social services of Hizb Allah bring political legitimacy and increase the political survival of the party in the future.

First, the reconstruction effort is but a part of a comprehensive strategy which is indirectly linked to the maintenance of the political and military campaign against Israel. Second, Hizb Allah schools intend to form new generations of Shiite voters who will have a similar political and social outlook and who will become a future constituency and power base. In the same spirit, healthcare and economic aid is provided. This shows that Hizb Allah does not attempt to challenge the state directly in a political or military confrontation. Instead it has opted for the long run, and the creation of a new "Shiite Man," politically dynamic and socially aware, who will change the political system in time. More importantly, Hizb Allah has set a standard of service within Lebanese society. 
This truly gives Hizb Allah a chance to survive political demise in the event of a change in regional political factors. The Maronite Social Fund's program follows the same strategy; after a sense of loss in political power, special attention is given to the socioeconomic development of the Maronite community. Education, the construction of low cost housing, healthcare, and agricultural programs enable the poorest to survive and to strengthen social cohesion and community ties. It is thus important to underline that in a country where the people feel alienated from government decision makers, grass root socioeconomic policies are vehicles to political leverage, legitimacy, and survivability.

The main problem for the Maronites is embodied in the Taef Agreement which --some feel-- has torn the apparel of the state from their hands. The political situation has been inversed, apparently in favor of the Muslim community. Indeed, the power is in Syrian hands. The Maronite Patriarch finds that there is no political balance between the communities, and the Syrian occupation keeps a segment of the Christian population from participating in the political life of the Lebanese government. For example, the Christian ministers and deputies come from the peripheral regions, not from the center of Christian power in the Metn or Kessrouan regions. Among the present Christian Members of Parliament are members of the Hizb al Suri al Qawmi al ljtimaai, the Syrian National Social Party. Its main ideology is the establishment of Greater Syria, which includes Syria, Lebanon, Iraq, Jordan, Palestine (and Israel), and Cyprus.

Christians and Muslims have co-existed for centuries; Shiites and Maronites have lived together in the same villages and still cooperate today. However, many Maronites are frustrated by the Syrian presence who opposes a real representation of their community. The situation is no better for the Muslims. The Sunnis are afraid of the Shiites, and all are dependent on foreign powers. Consequently, cooperation between the communities on the social level 
is an important step, but the future will have to see a political cooperation between Muslims and Christians if Lebanon is to survive as a symbol of coexistence.

The Lebanese people fought one another during the Civil War, but, still, Lebanon stands. If the militias of different ideological and religious groups fought one another, the people did not forget their past co-existence. It would be interesting to see what a man like Imam Musa Sadr would do in Lebanon today.

As we have seen in the first chapter, Imam Musa Sadr was a man of dialogue and of social change; his involvement with Archbishop Haddad, and even his social movement, Harakat al Mahrumin, show that he was not only thinking of the betterment of the Shiite people, but of all the poor and oppressed people in Lebanon. We can only wonder as to his possible political stance if he had been in Lebanon at the height of the war. Would he have supported the policies of a Nabih Berri, or would he have encouraged the creation of a movement like Hizb Allah?

We cannot answer this question today; we can only remember what Imam Musa Sadr stood for; he stood for justice and for socio-economic well being. He stood against oppression, the political and economic oppression of any man, any group by another. His actions, though immersed in sectarian politics, were not limited to them. His vision was elevated beyond the myopic lenses of political confessionalism; he was an Iranian Shiite cleric who was truly Lebanese and who understood that this tiny country presented a challenge to the whole world. The challenge of understanding the ideas, the aspirations, and the fears of the "other".

The fears of the Maronites reside in their perceived loss of political power in Lebanon, and in the possibility of the creation of an Islamic state in the future. The only way to resolve the situation is by consistently pursuing, like Iranian 
President Sayyid Mohammed Khatemi has suggested recently, a dialogue of civilizations. But can words convince a growing European xenophobia facing a growing Muslim immigration? Or would a successful co-existence of Christians and Muslims in Lebanon be more convincing? It has always been the destiny of this country to foster that co-existence prompting observers to label it "the bridge between East and West".

However, can the Christians accept the idea of an Islamic state? Similarily, can Shiite Islam, through ljtihad, accept the separation of religion and the state?

In his book, Meditations on Islamic Political Thought, Ayatollah Fadl Allah did not take that step. But, if the dialogue of civilizations is to have any institutional meaning in Lebanon, true cooperation will have to transcend old fears and rivalries. The Lebanese people have proven that for at least thirty years (1943-1975), they succeeded in living together peacefuly. Dialogue should be encouraged and maybe enforced institutionally through the creation of an official Muslim-Christian Bureau in charge of dealing with the socio-politicoreligious problems that might arise in a diverse society. For if there exists one country in the world where the people can find a solution to the clash of civilizations, it is Lebanon.

Isn't it already astonishing to see that two ideologies represented by Hizb Allah, on the one hand, and the Maronite Church, on the other, cooperate together in mutual respect for the provision of social services the state has thus far ignored? A further evolution of socioeconomic policies could be a catalyst to the creation of a true civil society in Lebanon where the focus of politicians will not be on religion but on the betterment of the people. A Lebanon where political equality and economic justice exist could become a model for the whole Middle East. 
Appendix 1

Development projects in Lebanon are in such demand that neither the state nor the religious communities are able to cater to the needs of the whole population. Private associations of benevolent citizens also play a substantial role in alleviating the suffering of the poor. There are numerous private associations in Lebanon; in the following I will describe, as an example, the work of one of these apolitical organizations.

Auxilia ${ }^{182}$ was founded in 1992 and started its work in 1993. It is the product of the Association of dentists of the Lebanese University which started its benevolent work in the field of dentistry in 1987. The Association treated patients from one welfare center at first, but soon realized the need of the population for more wide-ranging aid in the field of medicine, schooling and job placement. In 1992, Auxilia was founded for different reasons:

- foreign aid halted in Lebanon because the country was no longer at war.

- Many families lost their sole supporter.

- The economy and living standards were lagging.

- There was no spirit of community solidarity. ${ }^{183}$

Because of this horrid situation, Auxilia officials set out to accomplish several objectives:

${ }^{182}$ Auxilia means "help" or "rescue" in Latin.

${ }^{183}$ Information pamphlet in Arabic from Auxilia, in the possession of the author. 
First, it was deemed pivotal to maintain the family unit by keeping its members under one roof. A spirit of solidarity and partnership had to be created as help would be sought from within Lebanon as well as from without. ${ }^{184}$

Second, Auxilia acts as the intermediary between the donor and the people in need. Individuals or a whole family can sponsor a family in need or just one of its members. A group of people can also decide to sponsor a family by pooling their donations; companies, banks, or associations can ask their employees or members for donations which would then be sent to the Auxilia administration for distribution. Finally, fundraising in schools and universities can bring a steady flow of income as well.

Third, Social workers visit families and investigate the needs of the family. Findings are then submitted to the Auxilia Board of Directors who decide whether to help the family or not. Usually, the targeted group are families who lost their provider, poor families with children under the age of 18 , and families who do not already receive enough assistance from another organization. Sponsors supply the recipient with US $\$ 10$ for medical needs, US $\$ 25$ for food, and US $\$ 50$ for education a month; in order to create a certain stability in the recipient's life, the sponsor must make a commitment of at least a year. In addition, single mothers are helped with finding part time employment in order to encourage initiative and enable them to be at home when children return from school. ${ }^{185}$

\footnotetext{
${ }^{184} \mathrm{Dr}$. Nicolas Hajjar, Vice president of Auxilia. Interview with the author on "Auxilia and the Poor", Beirut, Lebanon, 9-2-1997. ${ }^{185}$ Ibid.
} 
Auxilia is still in need of donors and sponsors as poverty in Lebanon is still a problem of national proportions. What Auxilia executives have not been able to tap yet is the awesome financial ability of the Lebanese Diaspora which still shies away from Lebanese political and social concerns. 


\section{Appendix II}

Pictures of Lebanon

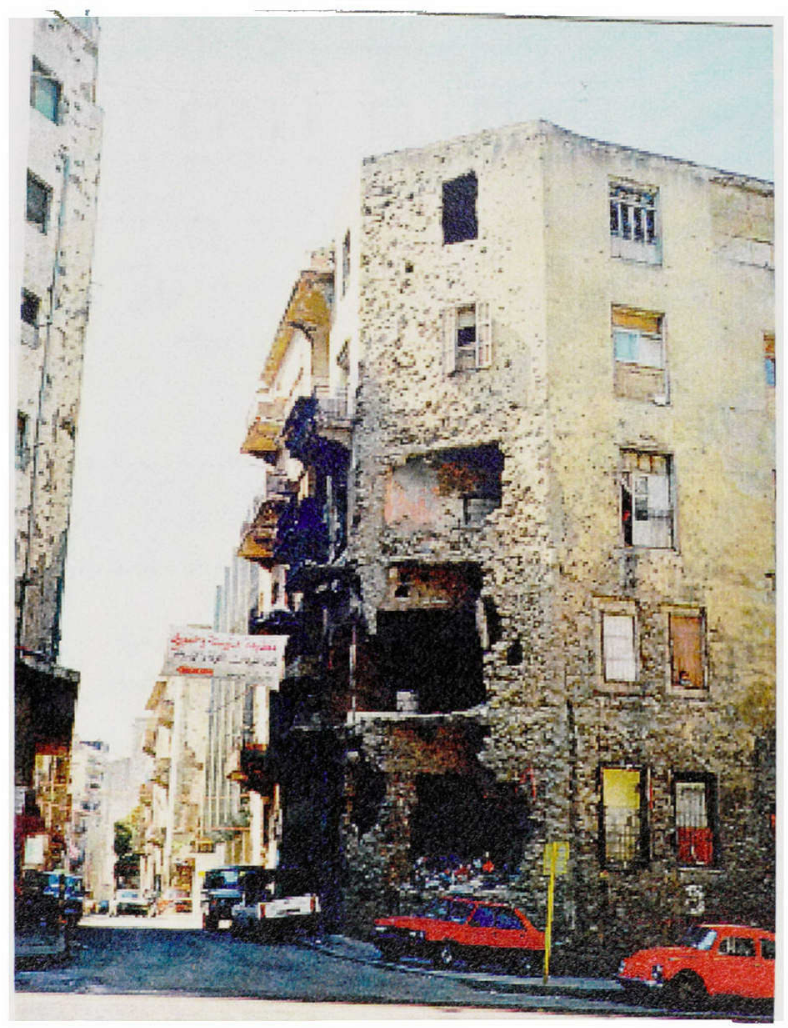

One of the many remaining destroyed buildings in downtown Beirut, still inhabited by refugees. (Photographed by Serge Akl). 


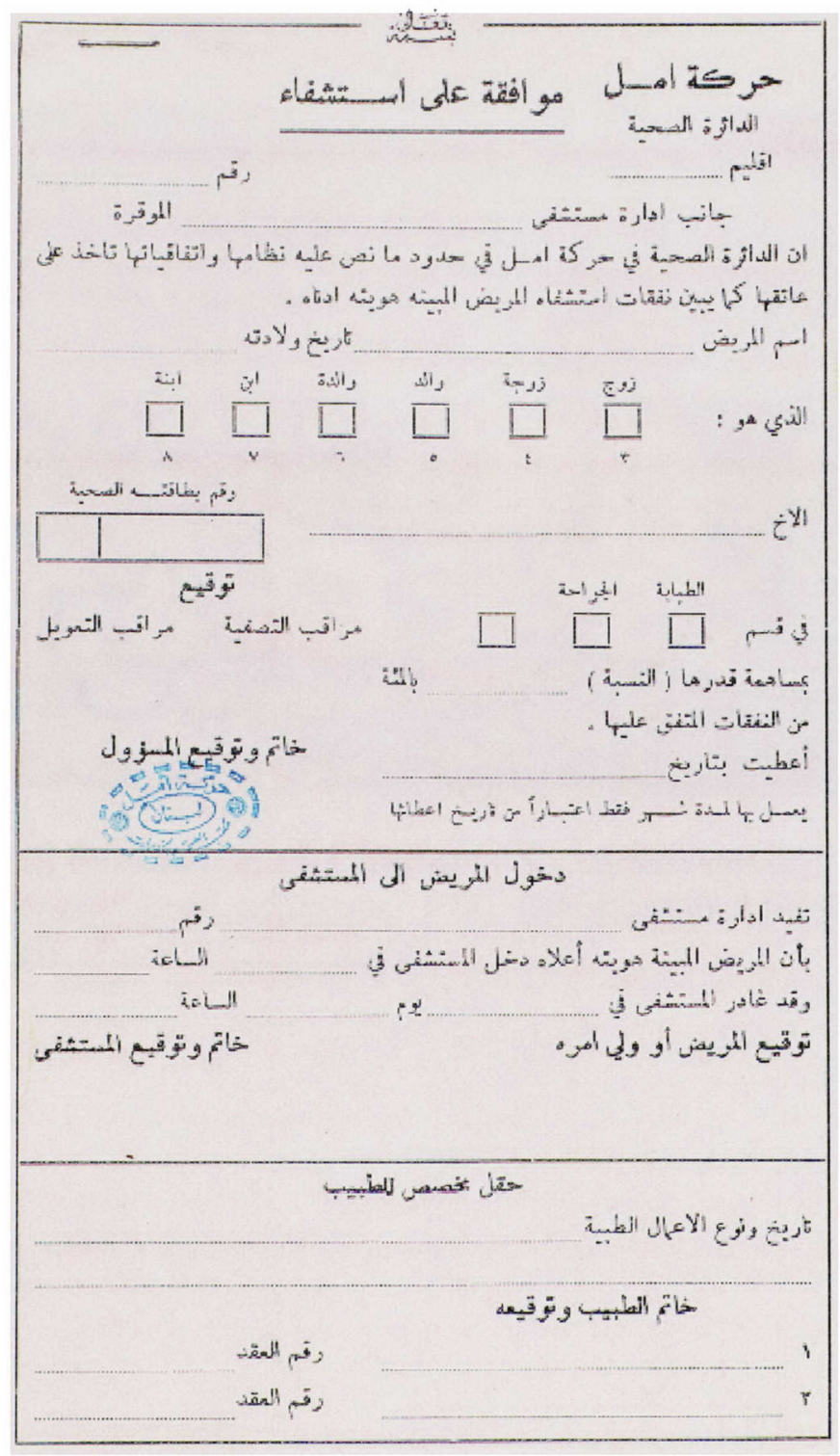

An Amal medical form; the Amal sponsored patient submits it to his doctor who keeps a copy. The doctor can later present it to Amal authorities for payment of his services. (Form provided by Amal Social Services). 


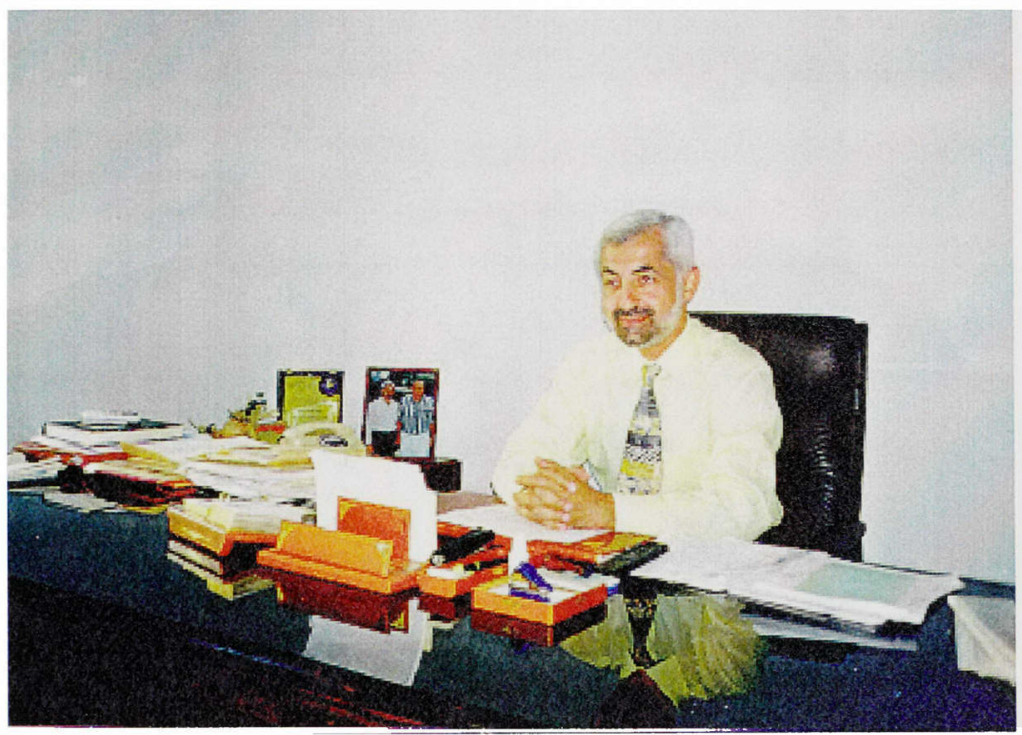

Hajj Bassem Lamaa, Director of Social Services of Harakat Amal, September 1997. (Photographed by Serge Akl). 


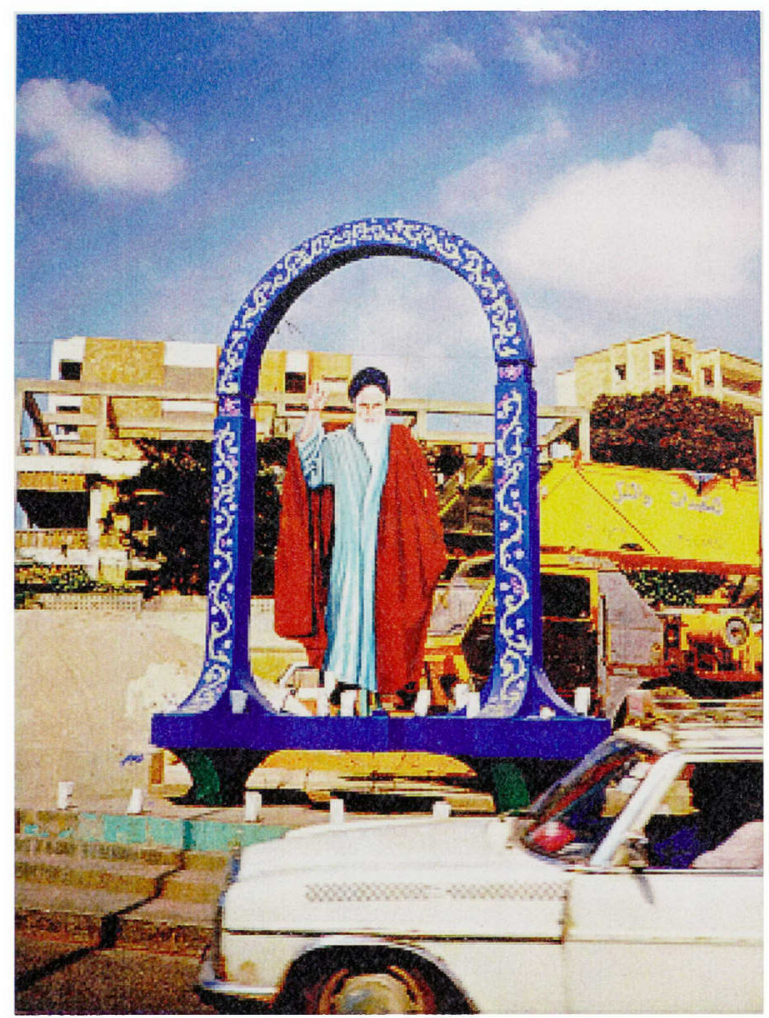

A representation of Ayatollah Khomeini at the outskirts of the Southern Suburbs. (Photographed by Serge Akl). 


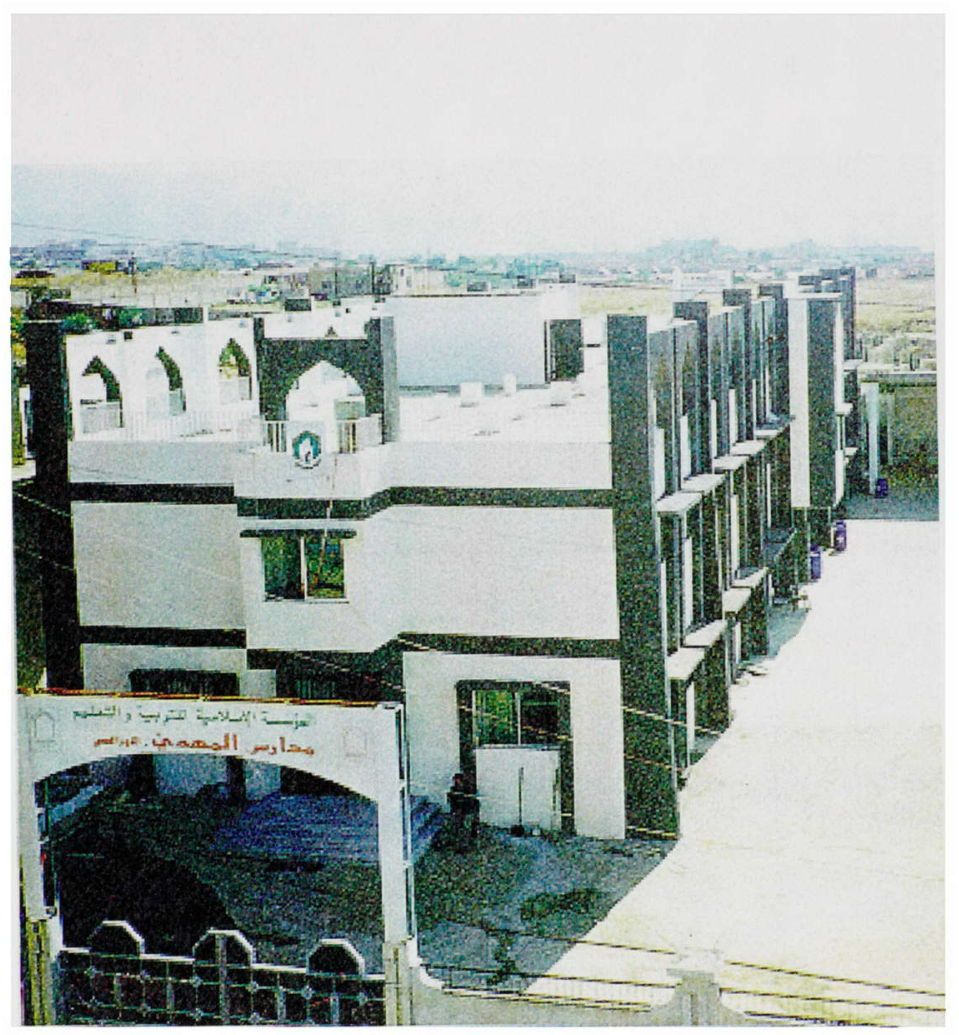

The Ouzaii school in Beirut. (Photograph courtesy of Hizb Allah) 
Reconstruction of destroyed homes by Jihad al Bina'.

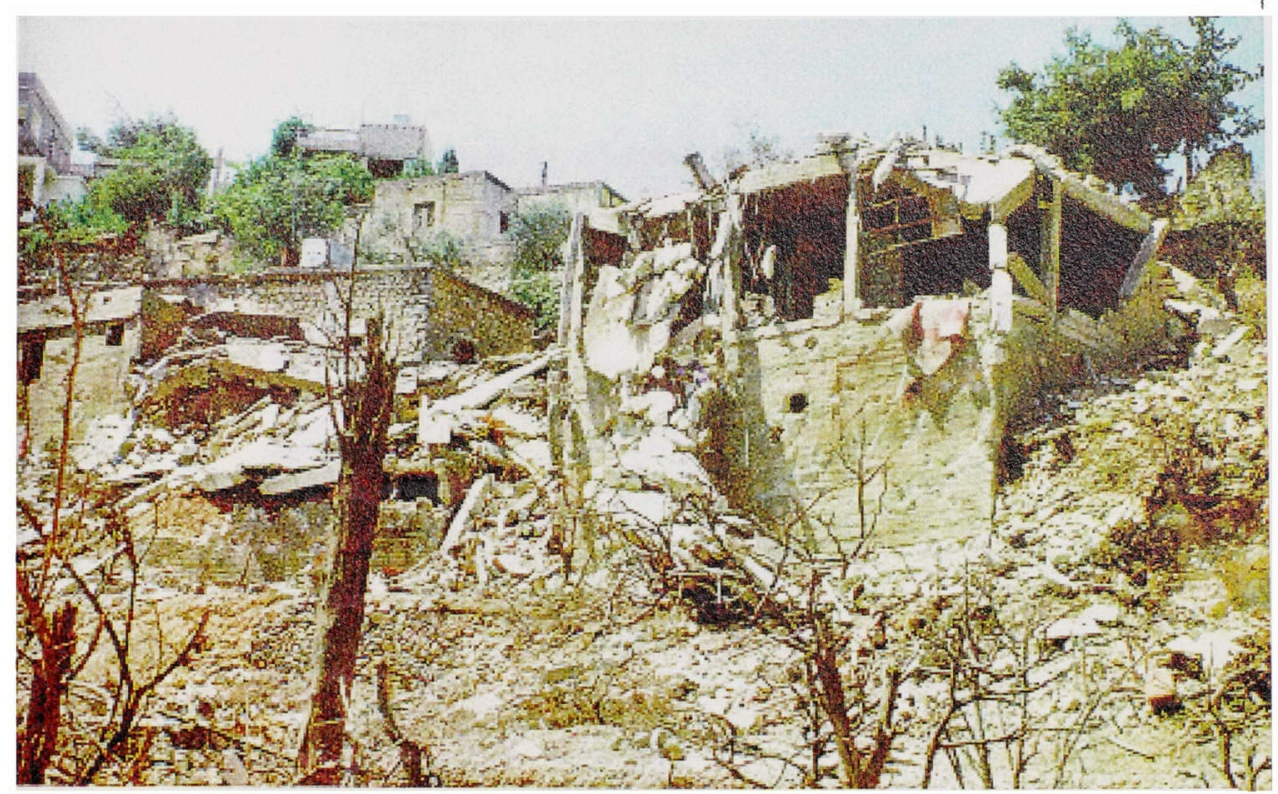

Before...

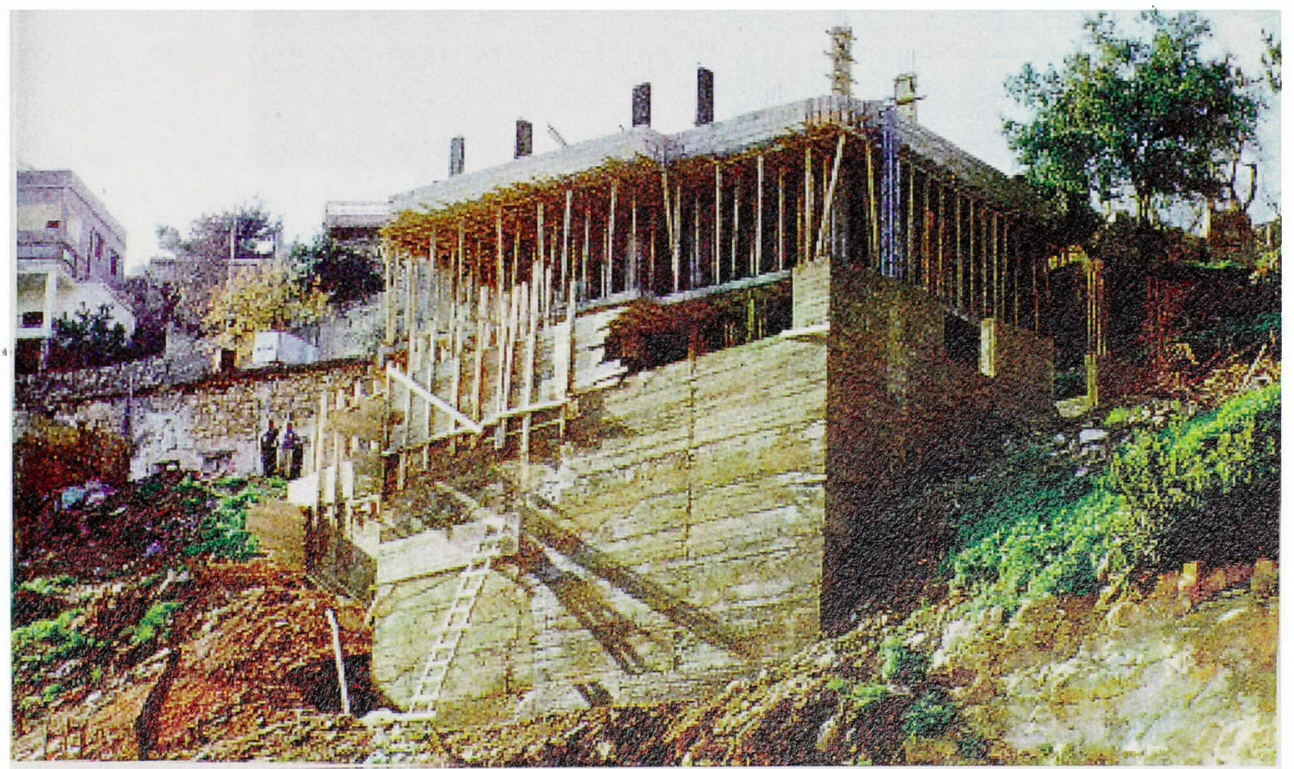

... and after. (Photographs courtesy of Jihad al Bina', Hizb Allah) 


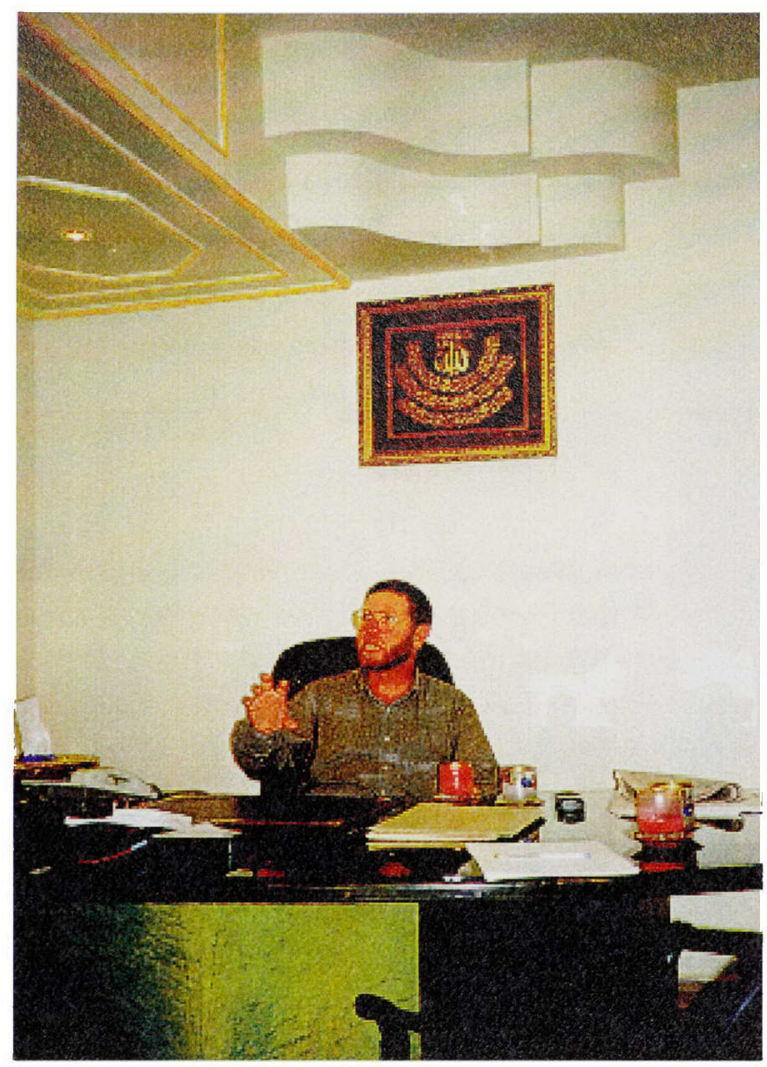

Hajj Hussein Al Chami, Director of the Social Services of Hizb Allah, September 1997. (Photographed by Serge Akl). 